\title{
Schoolverlaters tussen onderwijs en arbeidsmarkt 2002
}

Citation for published version (APA):

Wolbers, M. H. J., \& de Vries, M. R. (2003). Schoolverlaters tussen onderwijs en arbeidsmarkt 2002. Researchcentrum voor Onderwijs en Arbeidsmarkt, Faculteit der Economische Wetenschappen. ROA Reports No. 9 https://doi.org/10.26481/umarep.2003009

Document status and date:

Published: 01/01/2003

DOI:

10.26481/umarep.2003009

Document Version:

Publisher's PDF, also known as Version of record

\section{Please check the document version of this publication:}

- A submitted manuscript is the version of the article upon submission and before peer-review. There can be important differences between the submitted version and the official published version of record.

People interested in the research are advised to contact the author for the final version of the publication, or visit the DOI to the publisher's website.

- The final author version and the galley proof are versions of the publication after peer review.

- The final published version features the final layout of the paper including the volume, issue and page numbers.

Link to publication

\footnotetext{
General rights rights.

- You may freely distribute the URL identifying the publication in the public portal. please follow below link for the End User Agreement:

www.umlib.nl/taverne-license

Take down policy

If you believe that this document breaches copyright please contact us at:

repository@maastrichtuniversity.nl

providing details and we will investigate your claim.
}

Copyright and moral rights for the publications made accessible in the public portal are retained by the authors and/or other copyright owners and it is a condition of accessing publications that users recognise and abide by the legal requirements associated with these

- Users may download and print one copy of any publication from the public portal for the purpose of private study or research.

- You may not further distribute the material or use it for any profit-making activity or commercial gain

If the publication is distributed under the terms of Article $25 \mathrm{fa}$ of the Dutch Copyright Act, indicated by the "Taverne" license above, 


\section{Schoolverlaters tussen onderwijs en arbeidsmarkt 2002}

ROA-R-2003/9

Researchcentrum voor Onderwijs en Arbeidsmarkt

Faculteit der Economische Wetenschappen en Bedrijfskunde Universiteit Maastricht

Maastricht, juli 2003 


\section{Inhoud}

Voorwoord

Samenvatting $\quad \mathrm{V}$

1 Bestemming van gediplomeerde schoolverlaters in $2002 \quad 1$

1.1 Bestemming van gediplomeerde schoolverlaters 1

1.2 Kwalificerende vervolgtrajecten 3

1.3 Intrede op de arbeidsmarkt 12

2 Schoolverlaters van het VBO en MAVO: de instroom in het secundair beroepsonderwijs vergeleken 31

2.1 Achtergrondkenmerken en behaalde examenniveau . $\quad 31$

2.2 De instroom van MAVO- en VBO-schoolverlaters in het secundair
beroepsonderwijs

2.3 Aansluiting met het secundair beroepsonderwijs 36

2.4 Samenvatting $\quad 43$

3 De aansluiting tussen behaalde kwalificaties en gevonden functie voor schoolverlaters van de BOL en de BBL $\quad 47$

3.1 Wie hebben geen aansluitende functie? 48

3.2 Waarom werkt een aantal schoolverlaters niet in een aansluitende functie? $\quad 50$

3.3 De arbeidsmarktpositie van schoolverlaters die niet werkzaam zijn
in een aansluitende functie

3.4 Samenvatting 59

4 De waarde van een startkwalificatie: verschillen tussen jaren en sectoren 61

4.1 Inleiding 61

4.2 Onderzoeksopzel 61

4.3 Verschillen tussen jaren $\quad 62$

4.4 Verschillen tussen sectoren

4.5 Samenvatting $\quad 72$

$\begin{array}{ll}\text { Literatuur } & 77\end{array}$

Enkele centrale begrippen 
$\longrightarrow$ 


\section{Voorwoord}

Wat gaan gediplomeerde schoolverlaters na hun opleiding doen? Hoe is de alansluiting met het vervolgonderwijs? Als ze naar de arbeidsmarkt gaan, hoe snel krijgen ze dan werk? En sluit dat werk dan ook aan op de gevolgde opleiding? In welke mate verschillen opleidingen in de positie die ze innemen op de arbeidsmarkt? En zijn er verschillen tussen onderwijsinstellingen in de positie van hun afgestudeerden? Sinds 1991 voert het Researchcentrum voor Onderwijs en Arbeidsmarkı (ROA) in samenwerking met DESAN Research Solutions ${ }^{1}$ enkele grootschalige onderzoeken uit onder recente schoolverlaters en pas afgestudeerden waarmee op dit soort vragen een antwoord kan worden verkregen. Het voorliggende rapport Scboolverlaters tussen onderwijs en arbeidsmarkt 2002 gaat hoofdzakelijk in op de bestemming van gediplomeerde schoolverlaters en afgestudeerden van her school- of studiejaar 2000/2001. De resultaten die worden gepresenteerd zijn gebaseerd op het onderzoek dat in het najaar van 2002 over de volle breedte van het Nederlandse onderwijsstelsel is uitgevoerd en ze hebben betrekking op de situatie van schoolverlaters en afgestudeerden ongeveer anderhalf jaar na het voltooien van de opleiding. In totaal zijn bijna 100.000 schoolverlaters en afgestudeerden benaderd afkomstig uil ruim 125 onderwijsinstellingen. De totale respons bedroeg $44 \%,{ }^{2}$ De verzamelde gegevens vormen tezamen het door het ROA ontwikkelde Schoolverlatersinformatiesysteem (SIS). Dit informatiesysteem is gelsaseerd op een drietal grootschalige enquêtes die volgens een geïntegreerd model worden uitgevoerd.

Allereerst betreft het de enquête Registratie van Uitstroom en Bestemming van Schoolverlaters (RUBS). Deze enquete is gericht op schoolverlaters van het algemeen voortgezet onderwijs (AVO), het (individueel) voorbereidend beroepsonderwijs ((I)VBO) en de beroepsopleidende (BOL) en beroepsbegeleidende leerweg ( $\mathrm{BBL}$ ) van het secundatir beroepsonderwijs. Datarnatast gat het om de HBO-Monitor en WOMonitor. Dit zijn volledig vergelijkbare enquêtes gericht op algestudeerden van het hoger beroepsonderwijs (H13O) en het wetenschappelijk onderwijs (WO), Ze worden uitgevoerd onder toezicht van respectievelijk de HBO-Raad en de Vereniging van Samenwerkende Nederlandlse Universiteiten (VSNi).

De drie schoolverlatersonderzoken hebhen ieder een dubbele doelstelling. In de cerste plats fungeren ze als instrument voor kwaliteitszorg voor onderwijsinstedlingen Deelnemende onderwijsinstellingen ontvangen daartoc een uniek en vertrouwelijk instellingsrappon met de resultaten van hun 'eigen' schoolverdaters of afgestuderelen.

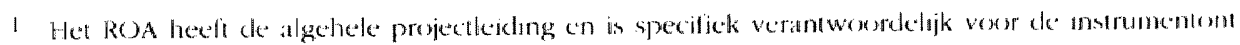

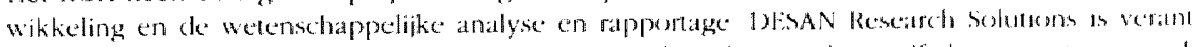

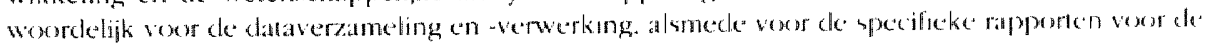

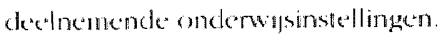

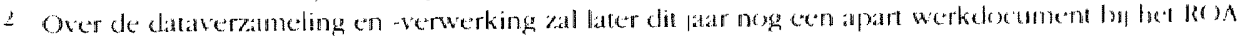


In de desbetreffende rapporten worden deze resultaten direct vergeleken met het lar delijke beeld voor de onderscheiden opleidingen. Deze instellingsrapporten worde gebruikt als instrument om de eigen opleiding te evalueren, bijvoorbeeld in het kade van cen visitatie. Ook worden de gegevens gebruikt om (aankomende) studenten voc te lichten over de verwachte beroepsperspectieven. De tweede doelstelling van de dri schoolverlatersonderzoeken betreft het genereren van een statistisch betrouwbare, lar delijk representatieve databron over de transitie van school naar werk of vervolgonde wijs. Door het grootschalige karakter van de onderzoeken en de goede onderling afstemming, vormen de huidige schoolverlatersonderzoeken RUBS, HBO-Monitor e WO-Monitor de belangrijkste en meest gedetailleerde informatiebron over de besten ming van schoolverlaters in Nederland. ${ }^{3}$

Het afgelopen jaar zijn de vragenlijsten van RUBS ingrijpend gewijzigd. ${ }^{4}$ De achtergron van deze herziening had een aantal oorzaken. De meest cruciale zijn de teruglopend respons, de (te) lange vragenlijsten, de (te) complexe formulering van vragen en he grote aantal varianten van vragenlijsten voor verschillende onderwijssoorten en -secto ren. De belangrijkste verbeteringen die zijn aangebracht behelzen de volgende punter Er zijn nu vragenlijsten ontwikkeld waarbij een onderscheid is aangebracht tussen ee harde kern die aan iedereen wordt gevraagd en enkele, jaarlijks wisselende module die aan selecties van schoolverlaters worden voorgelegd. Hierdoor is het mogelijk on de hoeveelheid informatie te vergroten zonder dat de vragenlijst langer wordt. Verder de nieuwe vragenlijst verkort met behoud van de wezenlijke informatie die nodig is on de transitie van school naar werk goed in beeld te brengen, de vraagformulering is ve eenvoudigd zonder onnodige toelichtingen bij vragen, het aantal varianten van vrager lijsten is teruggebracht en er zijn meer algemene responsverhogende activiteite doorgevoerd zoals een vergroting van het lettertype dat wordt gebruikt in de vragenlijs Hoewel een definitieve evaluatie van de genoemde veranderingen nog moet plaatsvir den, kan nu al worden opgemerkt dat de veranderingen responsverhogend hebbe gewerkt en clat zij - bij vergelijking van kerncijfers over de jaren heen - nauwelijks to rendbreuken heblben geleid. ${ }^{5}$

Dit rapport richt zich met name op degenen die zich in beleidsmatige zin bezighoude met de doorstroom van gediplomeerde schoolverlaters binnen het onderwijssysteet encrzijds en de arheiclsmarkipositie van gediplomeerde schoolverlaters anderzijd Daturbij word met name gedacht aan de landelijke en regionale overheid, sociale par ners, Centra voor Werk en Inkomen (CWI) en het (georganiseerde) onderwijsveld. D) gegevens in dil rapporl geven een beeld van de recente ontwikkelingen in het doo stroomgedrag en de arbeidsmarktpositie van gediplomeerde schoolverlaters.

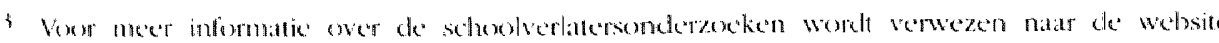

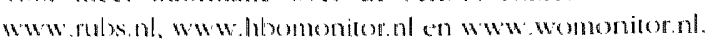

1 De bedocling is dal de vagenlijsten van de HBO-en WO-Monitor in 2003 op overeenkomstige wij;

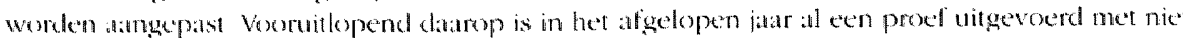

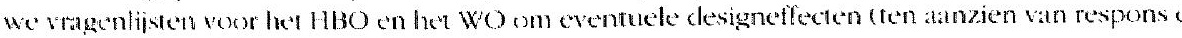
"venturele trendlorewkent vast te stellen. 
In dit rapport wordt alleen ingegaan op gediplomeerde schoolverlaters en afgestudeerden. Bovendien gaat het om de uitstroom van voltijdopleidingen. De gegevens zijn veelal verbijzonderd naar onderwijssoort en opleidingssector.

Bij dit rapport verschijnt een Statistische Bijlage, waarin de belangrijkste resultaten in tabelvorm zijn samengebracht. Naast het rapport Scboolverlaters Iussen onderwijs en arbeidsmarkt 2002 verschijnt nog een aantal afzonderlijke rapporten over de arbeidsmarktpositie van hoger opgeleiden. In de eerste plaats betreft dit de rapportage van de HBO-Monitor, De arbeidsmarktpositie van afgestudeerden van bet boger beroepsonderwijs 2002, die wordt uitgegeven door de HBO-Raad. Hoewel de belangrijkste informatie van de afgestudeerden van het HBO ook in het voorliggende rapport is opgenomen, wordt voor meer gedetailleerde informatie verwezen naar dit afzonderlijke rapport. Hetzelfde geldt voor de rapportage van de WO-Monitor, De arbeidsmarktpositie van afgestudeerden van de Nederlandse universiteiten, die in een later stadium door de VSNU zal worden uitgebracht. Verder verschijnt er nog een afzonderlijk rapport over de afgestudeerden van de kunstvakopleidingen (Kunstenmonitor).

Het voorliggende rapport is als volgt opgebouwd. Hoofdstuk 1 gaat in hoofdlijnen in op de bestemming van gediplomeerde schoolverlaters. Allereerst wordt de bestemming van schoolverlaters - verder leren of aanbieden op de arbeidsmarkt - beschreven. Vervolgens wordt ingegaan op degenen die na het verlaten van de opleiding zijn gaan verder leren. Daarna komt de arbeidsmarktintrede van gediplomeerde schoolverlaters uitgebreid aan bod. Niet alleen zal worden ingegaan op verschillende aspecten van werkgelegenheid en werkzekerheid (werkloosheid, flexibele aanstelling, e.d.), maar ook op meer kwalitatieve aspecten van het werk (beloning, de mate waarin de gevonden baan aansluit bij de gevolgde opleiding, e.d.). Dit resulteert in een typering van de arbeidsmarktpositie van de onderscheiden opleidingssectoren. De overige drie hoofdstukken zijn thematisch van aard. In hoofdstuk 2 wordt bestudeerd of er verschillen bestaan tussen het VBO en hel MAVO wat betreft de aansluiting tussen cle afgesloten opleiding en de vervolgopleiding in het secundair beroepsonderwijs. Ten eerste word bekeken welk deel van de schoolverlaters van het VBO en het MAVO is ingestronmel in het secundair beroepsonderwijs en op welk niveau. Ten tweede wordt onderzochl wic: van hen de vervolgopleiding in the secundair heroepsonderwijs voortijlig verliat en zonder startkwalificatie de arbeiclsmarkı betreedt. Ten clerde wordt nagegatan hoe cle aansluiting met de vervolgopleiding wordt ervaren door verder lerende scheolverlaters van het VBO en het MAVO. In hoofdstuk 3 wordt onderzocht of het verschil in alandactu voor beroepsgerichte vaardigheden tussen de BOL en de BBL gevolgen heeli vorr ck arbeidsmarktintrede van beide groepen schoolverlaters. Daartoe wordt allereersi nagegaan in hoeverre de aansluiting tussen de gevolgde opleidingsrichting en de gevonden baan verschilt tussen de BOL en de BBL. Vervolgens word bestudeerd in hoverre het werken buiten de eigen valkrichting gevolgen heeft voor de arbeidsmarktpositic van

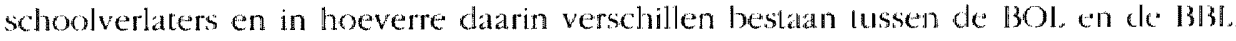
Hoofdstuk 4 gaat in op de waarde van een startkwalificatie. Hel is een vervolg op een eerder onderzoek waarin werd geconcludeerd dat het gekozen niveau 2 van hel sec un dair beroepsonderwijs als startkwallificatie redelijk adequat is." 
De vraag is echter of de conclusiet van dit onderzoek - gehouden in een periode hoogconjunctuur - ook overeind blift in tijden dat het minder goed gaat op de arbe markt. Om dit te onderzoeken wordt het eerdere onderzoek hier herhaald, maar nu geleken met een cohort van schoolverlaters dat in relatief slechtere omstandigheden arbeidsmarkt heeft betreden. Bovendien wordt de eerdere analyse uitgebreid door schillen tussen opleidingssectoren in beeld te brengen als het gaat om de waarde niveau 2 opleidingen.

De projectleiding van Schoolverlaters tussen onderwijs en arbeidsmarkt 2002 berust dr. M.H.J. Wolbers, die tevens hoofdstuk 3 heeft samengesteld. De hoofdstukken 1, 2 4 zijn geschreven door drs. M.R. de Vries. De Statistische Bijlage is samengesteld d E.M.H.P. Soudant, Secretariële ondersteuning is verleend door M.H.J. Beenkens. SIS, waarop dit rapport is gebaseerd, werken verder mee dr. J.P. Allen, drs. P.W.L.J. Eijs, drs. T.G. Huijgen, P.J.E.G. van der Kolk. drs. G.W.M. Ramaekers, dr. H.F. Vaat en dr. R.K.W. van der Velden (allen werkzaam bij het ROA), alsmede drs. M.C.M.Th. Alphen, drs. H. van Dongen, drs. J. Hartkamp, ing. J.J. Rutjes en drs. R. Tjemmes (al werkzaam bij DESAN Research Solutions). Bij het onderzoek onder schoolverlaters de agrarische opleidingen wordt samengewerkt met STOAS onderzoek te Wagening We bedanken dr. Y.K.M. Kops en drs. M.A.M. van der Meys voor de plezierige sam werking.

Een speciaal woord van dank wordt gericht an de vertegenwoordigers van de fin ciers clie in de klankbordgroep zitting hebben: drs. C.P. Bakker (Ministerie van derwijs, Cultuur en Wetenschappen, directie BVE), drs. J.H. Donk (Ministerie Sociale Zaken en Werkgelegenheid, directie Arbeidsmarkt). mr. J.A. Guerand (Ministe van Landbouw, Natuurbeheer en Visserij, directie Wetenschap en Kennisoverdract J.A. de Hoog (Ministerie van Onderwijs, Cultuur en Wetenschappen, directie V (rs. F.S.A. Straatjes (Ministerie van Sociale Zaken en Werkgelegenheid, directie Anal en Onderzoek), dr. P.M. Veen (Ministerie van Onderwijs, Cultuur en Wetenschapp directic WO), dr. H.H. van der Velde (Ministerie van Onderwijs, Cultuur Wetenschappen, directic HBO), drs. P.H.J. Vrancken (Ministerie van Onclerwijs, Cultt en Weansedappen, directie BVE) en drs. R.G. van Zevenbergen (Ministerie Onclerwijs, Culture en Wetenichappen, direclie AP).

Matastricht, juli 2003

Proll. dr. J,A.M. Heijke

direceur 


\section{Samenvatting}

\section{Bestemming van gediplomeerde schoolverlaters}

Wanneer schoolverlaters hun opleiding succesvol hebben afgerond statan ze voor een belangrijke keuze. Ze kunnen besluiten om verder te gaan leren in een vervolgopleiding of ze kunnen betaald werk gaan zoeken. Daarnaast kunnen ze kiezen voor een combinatie van beide in de vorm van werken en leren via de BBL. Aan gediplomeerde schoolverlaters die in het school- of studiejaar $2000 / 2001$ de opleiding hebben verlaten is gevraagd wat hun belangrijkste bezigheid op het moment van enquêteren is. Het merendeel van de schoolverlaters van het AVO (MAVO, HAVO, VWO) zegt dan scholier of student te zijn. Voor het VBO geldt dat ongeveer de helft van de schoolverlaters scholier of student is. Verder combineert $27 \%$ van de VBO-schoolverlaters werken en leren via de $B B L$. Ongeveer de helft van de schoolverlaters van $B O L$ niveau $1 / 2$ en $B O L$ niveau $3 / 4$ heeft zich aangeboden op de arbeidsmarkt. Verder zegt $32 \%$ van de schoolverlaters van $\mathrm{BOL}$ niveau $1 / 2$ scholier of student te zijn en $15 \%$ gaat werken en leren via de $\mathrm{BBL}$. Bij $\mathrm{BOL}$ niveau $3 / 4$ is $42 \%$ verder gaan leren in een vervolgopleiding en $5 \%$ is naar een opleiding in de BBL gegaan. Het merendeel van de schoolverlaters van de BBBL. niveau $1 / 2$ en BBL niveau $3 / 4$ heeft zich angeboden op de arbeidsmarkt. Schoolverlaters van de BBL die niet de arbeidsmarkı betreden, blijven vaak werken en leren combineren. De meeste afgestudeerden van het $\mathrm{HBO}$ bevinden zich op de arbeidsmarkt. Daarnaast heefi $15 \%$ van de $\mathrm{HBO}$-afgestudeerden gekozen voor een vervolgstudie. Voor het WO geldt dat het overgrote deel van de afgestudecten de arbeidsmarkt heeft betreden. Schoolverlaters kunnen tijdens de opleiding hulp hebhen gekregen bij de keuze van een vervolgopleiding of baan, bijwoorbeeld in de vorm van voorlichting. In total is $72 \%$ van de schoolverlaters tevreden over deze hulp.

Gediplomeerde schoolverlaters van de lagere opleidingsniveaus gaan vaak verder met leren. Het merendeel van de schoolverlaters van de BBL en de hogere opleidingsniveaus betreedt de arbeidsmarkt.

\section{Kwalificerende vervolgtrajecten}

Het merendeel van de gediplomeerde schoolverlaters van hel AVO kiess voor exen vervolgopleiding. Voor schoolverlaters van het MAVO geldt dat ze valak vereler gatan fere'n in de BOL. scheolverlaters van het HAVO kiezen valk voor een studie in hel IIIBO en de meerderheid van de schoolverlaters van het vwO kiest vool (een studie in hed Wo. schoolvertaters van hel VBO gaan na het behalen van het diploma valk door nall hel secundair beropsonderwijs. Van de schomlverlaters van hed VIBO gaall $5.3 \%$ mall een

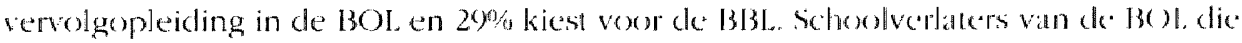
verder galan leren kiezen valk voor een vervolgstudie in he 1 HBO ), terwijl verder lerende schoolvertaters van cle BBI in de meeste gevallen op een hoger niveatu vercler gian in de BBL. Afgestudeerden van he $\mathrm{HBO}$ die kiezen voor een vervolgendeiding gation valak verder in het WO Voor de richting van de vervolgopleiding geld dat me namo 
opleiding. Daarnaast geldt dat relatief weinig afgestudeerden van het HBO verder ga studeren in een verwante beroepsopleiding.

De aansluiting tussen de afgesloten opleiding en de vervolgopleiding is over het al meen redelijk goed voor schoolverlaters. Van de verder lerende schoolverlaters he $13 \%$ de vervolgopleiding voortijdig verlaten in het eerste leerjaar. Voor de schoolve ters die de vervolgopleiding voortijdig hebben verlaten geldt overigens dat meer dan helft van studie is gewisseld. Verder vindt $85 \%$ van de verder lerende schoolverlaters een volledige dagopleiding zijn gaan doen dat de vervolgopleiding voldoende tot go aansluit bij de gevolgde opleiding. Voor schoolverlaters die hebben gekozen voor BBL geldt dat $88 \%$ zegt dat de vervolgopleiding voldoende tot goed aansluit bij gevolgde opleiding. In totaal geeft $79 \%$ van de verder lerende schoolverlaters aan, a teraf bezien, opnieuw dlezelfde opleiding te willen volgen.

Met name schoolverlaters van de sector techniek kiezen voor een vervolgopleiding i een verwante richting. De vervolgopleiding sluit over het algemeen goed aan bij d gevolgde opleiding.

\section{Intrede op de arbeidsmarkt}

Van de schoolverlaters die zich aanbieden op de arbeidsmarkt is in totaal $3 \%$ werkl anderhalf jaar na het verlaten van de opleiding. ${ }^{7}$ Het percentage werklozen is gen deld het hoogst voor schoolverlaters van BOL niveau $1 / 2(8 \%)$ en het AVO 7 Daarnaast is $5 \%$ van de schoolverlaters vier maanden of langer werkloos gewe Overigens is $86 \%$ van de schoolverlaters die zich hebben aangeboden op de arbe markt in het geheel niet werkloos geweest na het verlaten van de opleiding. De wo zekerheid is relatief groot voor schoolverlaters van de BBL, het $\mathrm{HBO}$ en het WO. deze onderwijssoorten geldt dat vrij weinig schoolverlaters werken in een flex dienstverlyand. Bij het $\mathrm{AVO}$, het VBO en de BOL is het aandeel schoolverlaters met flexibel dienstverhand gemiddeld genomen hoger. Verder geldt voor opleidin sectoren waar vrouwen zijn oververtegenwoordigd (gezondheidszog en gedrag matschappij) dat relatief veel schoolverlaters een deeltijdaanstelling hebben.

Van de schoolverlaters die zich hebben aangeboden op de arbeidsmarkt is $3 \%$ wer loos. Lager opgeleide schoolverlaters zijn vaker werkloos dan hoger opgeleide schoc verlaters. Ook zijn zij vaker werkzaam in een flexibel dienstverband.

In total heeft $71 \%$ van de schoolverlaters met betaald werk een baan die aansluit bi bereikte opleidingsniveau. Daarnaas! geldt dat $74 \%$ van de werkzame schoolverla een baan heeft die qua richting aansluit bij de gevolgde opleiding. De beloning schoolverlaters is in vergelijking met 2001 weinig toegenomen. Alléen bij het HBC

Dil percentage is relaticl hag, zeter gelet op de recente economische onrwikkelingen. Bedach chter worden dat deze groep sehoolverlaters op de arbeidsmatk is ingetreden in een periode 
het WO is het bruto uurloon van afgestudeerden met respectievelijk $3 \%$ en $4 \%$ gestegen. Tot slot blijkt dat het merendeel van de werkende schoolverlaters positief oordeelt over de aansluiting tussen de gevolgde opleiding en de huidige functie. Van de schoolverlaters met betaald werk vindt $85 \%$ dat de aansluiting tussen de gevolgde opleiding en de huidige baan voldoende tot goed is. Daarnaast geeft $77 \%$ van de werkzame schoolverlaters aan dat ze, achteraf bezien, opnieuw voor dezelfde opleiding zouden kiezen.

Ongeveer drievierde van de werkende schoolverlaters heeft een baan gevonden die qua niveau en/of richting aansluit bij de gevolgde opleiding. De aanvangssalarissen zijn in 2002 vrijwel gelijk gebleven aan die in 2001.

Tabel S.1

Enkele kernindicatoren per onderwijssoort

\begin{tabular}{|c|c|c|c|c|c|c|c|}
\hline Onderwijssoort & $\begin{array}{l}\text { Verder } \\
\text { leren }\end{array}$ & $\begin{array}{l}\text { Werk- } \\
\text { loosheid }\end{array}$ & $\begin{array}{c}\text { Flexibele } \\
\text { aanstelling }\end{array}$ & $\begin{array}{l}\text { Bruto } \\
\text { uurloon }\end{array}$ & $\begin{array}{c}\text { Minimaal } \\
\text { eligen } \\
\text { niveau }\end{array}$ & $\begin{array}{c}\text { Eigen/ } \\
\text { verwante } \\
\text { richting }\end{array}$ & $\begin{array}{l}\text { Zelfde } \\
\text { oplelding } \\
\text { opnieuw } \\
\text { klezen }\end{array}$ \\
\hline & $\%$ & $\%$ & $\%$ & $\varepsilon$ & $\%$ & $\%$ & $\%$ \\
\hline AVO & 87 & 7 & 39 & 5,68 & 72 & $x$ & $x$ \\
\hline VBO & 82 & 3 & 24 & 4,40 & 86 & 66 & $\mathrm{x}$ \\
\hline BOL niveau $1 / 2$ & 43 & 8 & 29 & 6,78 & 59 & 60 & 62 \\
\hline BOL niveau $3 / 4$ & 48 & 4 & 22 & 8,32 & 69 & 73 & 75 \\
\hline BBL. niveau $1 / 2$ & 31. & 2 & 15 & 8,06 & 58 & 71 & 75 \\
\hline BBL, niveru $3 / 4$ & 16 & 1 & 5 & 10,21 & 68 & 84 & 81 \\
\hline HBO & 27 & 3 & 13 & 11,91 & 77 & 78 & 77 \\
\hline Wo & 27 & 3 & 11 & 13,83 & 66 & 73 & 80 \\
\hline Totaal & 58 & 3 & 18 & 9,35 & 71 & 74 & 77 \\
\hline
\end{tabular}

$\mathrm{x}=$ vraag niet opgenomen

Schoolverlaters van het VBO en het MAVO vergeleken

De afgelopen jaren heeft in het voortgezet onderwijs een vernieuwingsproces platilsgevonden. Zo zijn onder andere het MAVO en het VBO samengevoegd lon het VMBSO) (voorbereidend middelbatr beroepsonderwijs). Het doel van deze verandering is ele aansluiting met de vervolgopleiding te verbeteren. Een interessante vraag darbif is in hoeverre schoolverlaters van het MAVO en het VBO van elkaar versedillen wall betreli de verdere onderwijslooplaan?

MAVO-schoolverlaters hebben gemiddeld genomen op een hoger niveau examen gedaan dan VBO-schoolverlaters. Hel behaalde examenniveau speelt cen belangrijke rol bij de keuze van schoolverlaters om verder te gaan leren, voor welke lecrweg $\%$ kic zen en op welk niveau ze verder gaan leren. Voor MAVO- en VI3O-sedhoslverlaters geddi dat met name schoolverlaters die op een lager niveau examen hebben gedalan valker he. onderwijs verlaten dan schoolverlaters die op een hoger niveau examen hedblon 
op een lager niveau instromen in het secundair beroepsonderwijs en minder vaak ki zen voor de BOL dan degenen die op een hoger niveau examen hebben gedaan.

Schoolverlaters van het MAVO doen op een hoger niveau examen dan degenen van het $V B O$. Het behaalde examenniveau heeft gevolgen voor de verder onderwijsloopbaan van MAVO- en VBO-schoolverlaters.

De voortijdige uitval van scholieren in het eerste leerjaar van de vervolgopleiding is e indicatie voor de aansluiting tussen de gevolgde opleiding en de vervolgopleiding. $\mathrm{Na}$ voren komt dat schoolverlaters van de sector VBO techniek minder vaak dan MAV schoolverlaters de vervolgopleiding voortijdig verlaten in het eerste leerjaar. Voor overige sectoren van het VBO geldt dat er wat dit betreft geen verschillen bestaan n het MAVO. Het merendeel van de MAVO- en VBO-schoolverlaters maakt in de vervol opleiding veel gebruik van cle vaardigheden zelfstandig werken, communicatie vaardigheden, samenwerken en nauwkeurig werken. Volgens MAVO- en VBO-sch olverlaters zijn de valardigheden samenwerken en nauwkeurig werken voldoende a bod gekomen in de afgesloten opleiding, maar ze vinden dat aan zelfstandig werken weinig aandacht is besteed. Daarnaast blijkt dat schoolverlaters van de sector $\mathrm{Vl}$ gezondheidszorg vaak zeggen dat communicatieve vaardigheden te weinig aan bod $z$ gekomen in de afgesloten opleiding. Verder vinden MAVO-schoolverlaters veel vah dan VBO-schoolverlaters dat computervaardigheden in de afgesloten opleicling onv doende aan bod zijn gekomen. Schoolverlaters van de sectoren VBO techniek en VH gezondheidszorg zeggen vaak dat in de opleiding meer aandacht had moeten word besteed an taalvaardigheid.

Schoolverlaters van het MAVO en het VBO verlaten ongeveer even vaak de vervolg. opleiding voortijdig in het eerste leerjaar. MAVO-schoolverlaters ervaren valak eer tekort aan computervaardigheden in de afgesloten opleiding. Schoolverlaters van de sectoren VBO techniek en VBO gezondheidszorg ervaren vaak een tekort aan taal. vaardigheden.

Wanneer MAVO- en VBO-schoolverlaters word gevtagd naar cle mate watrin de e? menvakken alansluiten bij de vervolgopleiding dan blijkt dat schoolverlaters van de st tor VBO conomic negatiever en schoolverlaters van de sector VBO gezondheidszo positiever ordelen over deze atansluiting dan MAVO-schoolverlaters. Bij de sector VI economie kunnen deze verschillen worden toegeschreven aan het examenniveau deze schoolverlaters heblyen behaald. Ook voor de aansluiting tussen de gevolg opleiding en de vervolgopleiding geld dat schoslverlaters van de sector VBO gezor heids\%org positiever oordelen dan MAVO-schoolverlaters. Wanneer rekening wo gehouklen met achtergrondkenmerken van schoolverlaters, het behaalde examen veau, de keuze van de lecrweg en het niveau van de vervolgopleiding dan zijn, na schoolverlaters van de sector VBO gezondheidszorg. schoolverlaters van de secto VIBO lechniek en VIBO economie positiever dan MAVO-schoolverlaters over de at sluiting fusien de gevolgde opleiding en de vervolgopleiding

Schoolverlaters van de sector VBO gezondheidszorg zijn het meest positief over de aan sluiting tussen de gevolgde opleiding en de vervolgopleiding. 


\section{De aansluiting tussen behaalde kwalificaties en gevonden functie}

In het Nederlandse onderwijsbeleid wordt sinds een aantal jaren veel waarde gehecht aan beroepsgerichte vaardigheden bij het startbekwaam maken van jongeren tijdens de overgang van school naar werk. Dit heeft er mede toe geleid dat een nieuwe kwalificatiestructurur is ingevoerd waarin een onderscheid wordt gemalakt tussen de beroepsopleidende leerweg (BOL) en de beroepsbegeleidende leerweg (BBL). Gediplomeerde schoolverlaters van de BOL en de BBL, worden formeel als gelijkwaardig beschouwd. Echter, de leerwegen verschillen van elkaar als het gaat om het curriculum. Binnen de BBL ligt de nadruk veel meer dan bij de BOL op het aanleren van vaardigheden via de beroepspraktijk. De vraag is of dit verschil in aandacht voor beroepsgerichte valardigheden via de praktijk tussen de BOL en de BBL gevolgen heeft voor de arheidsmarktintrede van beide groepen schoolverlaters.

Uit de uitgevoerde analyse blijkt dat bijna eenvierde van de schoolverlaters van het secundair beroepsonderwijs niet werkzaam is in een aansluitende functie. Diarbij geldt dat BOL'ers vaker in een niet-aansluitende functie werken dan BBL'ers. Deze verschillen kunnen voor een deel worden toegeschreven aan verschillen in andere relevante kenmerken van schoolverlaters. Eenderde van de schoolverlaters met een niet-a:msluitende functie doet dit op vrijwillige basis en zegt niet (meer) te willen werken in de richting waarvoor ze zijn opgeleid. Ongeveer eenvijfde heeft geen werk kunnen vinden datt aansluit bij de behaalde kwalificaties. Daarnaast worden ook een tegenvallend salaris, beperkte carrièremogelijkheden en werktijden die niet bevallen regelmatig als reden genoemd. Desondanks is nog altijd $65 \%$ van de schoolverlaters met een niemalansluitende functie bereid om te werken in een functie waarvoor ze feitelijk zijn opgeleid. Tussen onderwijssoorten en opleidingssectoren bestaan wat dit betreft verschillen. Zo willen schoolverlaters van de BOL wat vaker eventueel wel werken in een functie watavoor ze zijn opgeleid dan schoolverlaters van de BBL. Ook willen schoolverlaters die een opleiding heb gevolgd in de sector landbouw of gedrag en matschappij vaker eventueel wel werken in een functie die ansluit bij de belvalde kwalificalies. Vorot cen deel kunnen de"ze verschillen worden hogeschreven aan andere relevante versidhillen tussen schoolverlaters.

Ongeveer eenvierde van de schoolverlaters van het secundair beroepsonderwijs werkt - om verschillende redenen - niet in een functie waarvoor zij feitelijk zijn opgeleid. Dit aandeel is hoger bij de BOL dan bij de BBL.

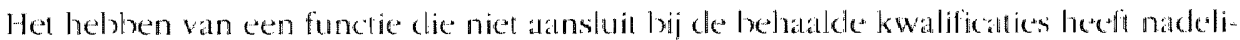
ge gevolgen voor de werkzekerheicl en cle kwaliteit van het werk. Schoolverlaters dice werkzaam zijn in een niet-ainsiluitende functie hebhen minder vaak vast work en vordienen minder dan schoolverlaters die in een a ansluitende functic werkatam zijn. Vour beide aspecten geld overigens dal een a anzientijk deel van deze versidhillen is $\mid x \cdot k$. schrijven aan verschillen in andere kenmerken tussen schoolverlaters. Verder zijn schoolverlaters met een nietalansluitende functie minder positief in hun oorden over de carrièremogelijkheden dan schoolverlaters die wel werkatam zijn in cen functice waarvoor zij zijn opgeleid. Orok zijn schoolverlaters met cen niet-aansluitende lune tic minder teverelen over de huidige functe en de destijds gemalake opleidingskeuze dan 
De negatieve arbeidsmarkteffecten van een gebrekkige aansluiting tussen de behaalc kwalificaties en de gevonden functie blijken niet sterker te zijn voor schoolverlaters va de BBL dan voor de BOL. In een aantal gevallen geldt juist het omgekeerde, nameli dat BOL'ers de vaardigheden die zij hebben aangeleerd tijdens de opleiding buiten h eigen beroependomein minder productief kunnen aanwenden dan BBL'ers.

Het werkzaam zijn in een functie die niet aansluit bij de behaalde kwalificaties heeft nadelige gevolgen voor de huidige arbeidsmarktpositie, de verwachte carrièremogelijkheden en de tevredenheid met opleiding en werk.

\section{$\overline{\text { De waarde van }}$ een startkwalificatie}

Recentelijk is het extern rendement van opleidingen op niveau 2 onderzocht en de vergeleken met het extern rendement van zowel de opleidingen die daar vlak bove zitten (de opleidingen op niveau 3 en 4) als de opleidingen die daar onder zitt (niveau 1 en VBO). De conclusie van deze analyse is dat het gekozen niveau 2 als sta kwalificatie redelijk adequat is. De vraag is of de conclusie van dit onderzoek - dat gehouden in een periode van hoogconjunctuur - overeind blifft in tijden dat het mind goed gaat op de arbeidsmarkt. Hiertoe is bovengenoemde analyse herhaald, maar vergeleken met een cohort van schoolverlaters dat in relatief slechtere omstandighed de arbeidsmarkt heeft betreden. Tevens zijn de opleidlingen van niveau 2 van versch lende opleidingssectoren vergeleken.

De waarde van opleidingen voor schoolverlaters op de arbeidsmarkt is onderzocht a de hand van een zestal indicatoren: de kans op deelname aan vervolgonderwijs, kans op betaald werk, de kans op een vaste baan, het niveau van het beroep. de ka op een baan in de eigen richting en het bruto uurloon. Daarbij is bekeken tussen wel opleidingsniveaus zich de grootste relatieve verbetering voordoet in termen v oplorengsten op de arbeidsmarkt. Schoolverlaters van de BOL en schoolverlaters van BBBL zijn apart geanalyscerd.

Wanneer als uitgangspunt wordt genomen dal een startkwalificatie op een zo groot a tal indicatoren een relatieve verbetering moet opleveren ten opzichte van de lage niveatus, dan voldoen opleidingen van BOL niveau 2 zowel in 1999-2000 als in 200 2002 als startkwalificatie. In 1999-2000 en in 2001-2002 leveren opleidingen van B niveatu 2 bij vier van de zes inclicatoren een relatief grote verbetering op in oplorengst ten opzichte van de lagere opleidingsniveaus. Voor een aantal indicatoren geld ze dat opleidingen van $13 O L$. niveau 1 al een relatief grote verbetering opleveren opzichte van het VBO. Bij de BBL leveren opleidingen van niveau 2 in 1999-2000 bij van de zes indicatoren een relatief grote verbetering op in opbrengsten ten opzichte de lagere opleidingsniveaus. In 2001-2002 geld dit maar voor twee van de zes indi toren. Dit geeft alan dat bij de BBL de grens van opleidingen die een relatieve goede bieden op de atreeidsmarkt minder vast ligt dan bij de BOL. Deze grens verschuift vo de $13 B L$ in een periode van economische neergang naar opleidingen naar een ho niveau. 


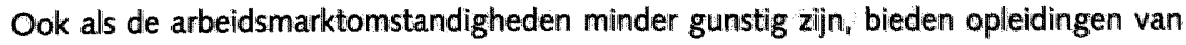
BOL niveau 2 schoolverlaters een relatief goede start op de arbeidsmarkt. Voor de BBL geldt daarentegen dat in een periode van economische neergang de grens van opleidingen die een relatief goede start bieden op de arbeidsmarkt verschuift naar opleidingen op een hoger niveau.

Wanneer per sector wordt bekeken tussen welke opleidingsniveaus zich de grootste relatieve verbetering in opbrengsten voordoet dan lijken opleidingen van BOL niveau 2 van de sector techniek te voldoen als startkwalificatie. Voor de sector techniek geldt namelijk dat opleidingen van BOL niveau 2 bij vier van de zes indicatoren een relatief grote verbetering opleveren ten opzichte van de lagere niveaus van deze sector. Bij de sectoren landbouw, economie en gezondheidszorg leveren opleidingen van BOL. niveau 2 bij drie van de zes indicatoren relatief goede opbrengsten ten opzichte van de lagere niveaus van deze sectoren. Voor de BBL geldt dat bij de sectoren techniek, economie en gezondheidszorg opleidingen van niveau 2 bij vier van de zes indicatoren een substantiële verbetering van de opbrengsten opleveren ten opzichte van de lagere niveaus van deze sectoren. Daarmee lijken opleidingen van niveau 2 van deze sectoren als startkwalificatie redelijk adequaat. Dit geldt in wat mindere mate voor de sector landbouw van de BBL waar opleidingen van niveau 2 bij drie van de zes indicitoren een grote relatieve verbetering opleveren ten opzichte van de lagere niveaus in cleze sector.

Sectoren in de BOL en de BBL verschillen enigszins van elkaar wat betreft de mate waarin opleidingen van niveau 2 schoolverlaters een redelijke startkwalificatie bieden. 


$$
\overline{\ldots \ldots \ldots}
$$




\section{Bestemming van gediplomeerde schoolverlaters in 2002}

\subsection{Bestemming van gediplomeerde schoolverlaters}

Schoolverlaters die hun opleiding succesvol hebben afgerond staan voor een belangrijke keuze. Ze kunnen doorgaan met leren en doorstromen naar een vervolgopleiding of ze kunnen een baan gaan zoeken en de arbeidsmarkt betreden. Ze kunnen ook voor een combinatie van beide kiezen in de vorm van werken en leren via de beroepsbegeleidende leerweg (BBL). In deze paragraaf wordt de bestemming van gediplomeerde schoolverlaters bekeken. De bestemming van gediplomeerde schoolverlaters is bepaald door respondenten te vragen naar hun belangrijkste bezigheid op het moment van ondervragen. Dit is ongeveer anderhalf jaar na het behalen van het diploma. Onder schoolverlaters worden in dit hoofdstuk degenen verstaan die met een diploma een voltijdopleiding hebben afgesloten.

Figuur 1.1

Bestemming van gediplomeerde schoolverlaters per onderwijssoort

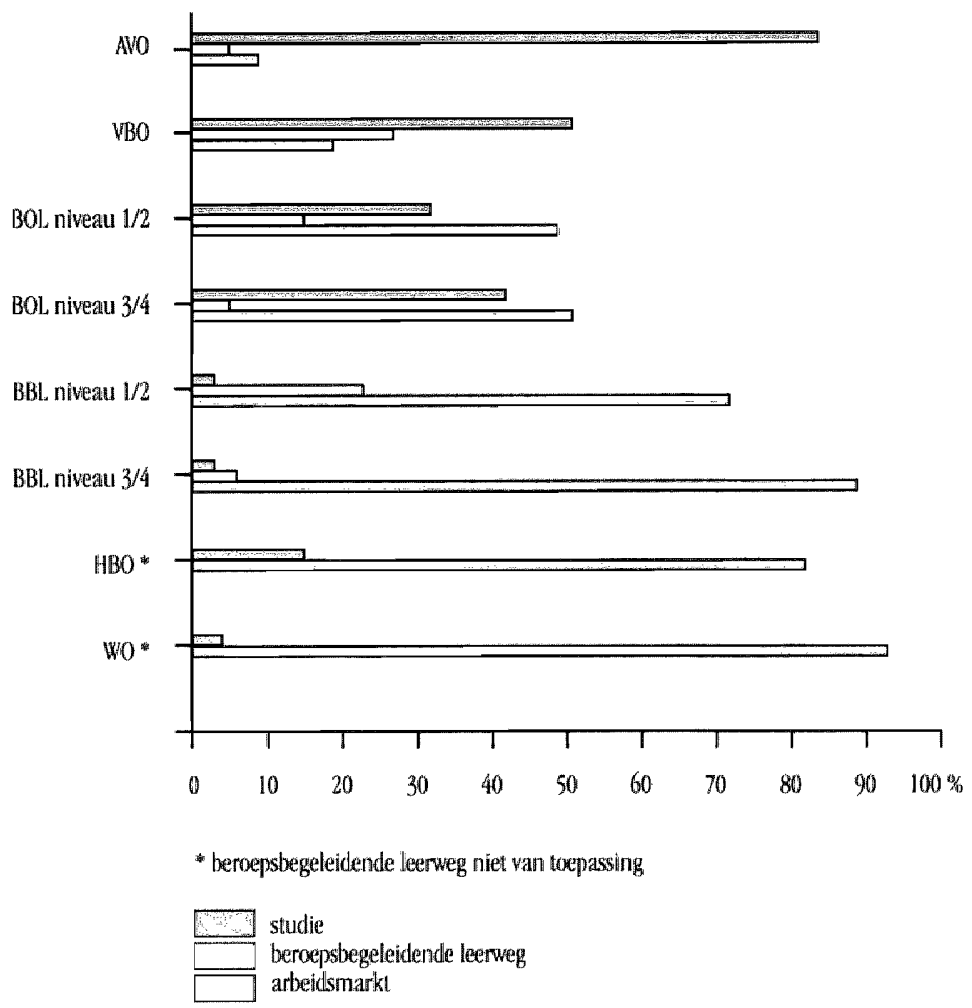


In figuur 1.1 is de bestemming van schoolverlaters weergegeven per onderwijssoort ( $\mathrm{Z}$ tabel Al.3 van de Statistische Bijlage). Uit deze figur blipkt dat het AVO en het VB schoolverlaters voornamelijk voorbereidt op een vervolgopleiding. Van de schoolverl ters van het AVO zegt $84 \%$ scholier of student te zijn anderhalf jaar na het behalen va het diploma. Daarnaast heeft $5 \%$ van de AVO-schoolverlaters gekozen voor een comb natie van werken en leren via de BBL. Voor het $\mathrm{VBO}$ (inclusief IVBO) geldt dat $51 \% \mathrm{v}$ de schoolverlaters aangeeft scholier of student te zijn en $27 \%$ is doorgestroomd naar BBL. Daarnaast is ongeveer eenvijfde van de VBO-schoolverlaters toegetreden tot arbeidsmarkt. Bij $\mathrm{BOL}$ niveau $1 / 2$ gaat $32 \%$ van de schoolverlaters naar een vervolgo leiding en $15 \%$ kiest voor een combinatie van werken en leren via de BBL. Voor BC niveau $3 / 4$ geldt dat $42 \%$ van de schoolverlaters is doorgestroomd naar een vervolgs die en $5 \%$ is vercler gaan leren in de BBL. Ongeveer de helft van de schoolverlaters $\mathrm{BOL}$ niveau $1 / 2$ en $\mathrm{BOL}$ niveau $3 / 4$ gaat naar de arbeidsmarkt.

Voor schoolverlaters van de BBL is de arbeidsmarkt de belangrijkste bestemming. V de schoolverlaters van BBL niveau $1 / 2$ heeft $72 \%$ zich aangeboden op de arbeidsmar bij BBL niveau $3 / 4$ heeft $89 \%$ van de schoolverlaters de arbeidsmarkt betred Schoolverlaters van de BBL die niet de arbeidsmarkt betreden, blijven vaak werken leren combineren. Ook veel afgestudeerden van het HBO bevinden zich anderhalf $\mathrm{j}$ na het behalen van het diploma op de arbeidsmarkt. Van de afgestudeerden van $\mathrm{HBO}$ is $82 \%$ toegetreden tot cle arbeidsmarkt. Daarnaast is $15 \%$ van de $\mathrm{HBO}$-afges deerden een vervolgstudie gaan doen. Voor het WO geld dat het overgrote deel van afgestudeerden zich op de arbeidsmarkt bevindt. Slechts een klein deel van de afges deerde WO-ers besluit verder te gaan studeren.

Schoolverlaters kunnen tijclens de opleiding hulp hebben gekregen bij de keuze van vervolgopleiding of een baan, bijvoorbeeld in de vorm van voorlichting. In hoeve zijn schoolverlaters tevreden over deze hulp? Figuur 1.2 laat dit zien. In deze figuu het percentage schoolverlaters vermeld dat tevreden is over de hulp die ze tijdens opleiding hebben gekregen bij de keuze voor een vervolgopleiding of een beroep. figuur I.2 bljikl alleteerst dat veel schoolverlaters van het AVO en het VBO tevreden over de hulp die ze tijdens de opleiding hebben gekregen bij de keuze van de vervo opleiding of het beroep. Van de AVO-schoolverlaters is $73 \%$ tevreden over deze hulp bij het V13O is dil percentage zelfs $79 \%$. Daarnaast $z e g 170 \%$ van de schoolverlaters BOL niveau $1 / 2$ tevreden te zijn over de hulp bij de keuze van de vervolgopleiding een beroep. Schoolverlaters van BOL niveau $3 / 4$ zijn wat dit hetreft minder tevred Van de schoolverlaters van BOL niveau $3 / 4$ geeft $62 \%$ aan teveden te zijn over de die te heblen gekregen bij de keuze van een verwolgopleiding of een beroep.

verder kom uit figuur 1.2 naar voren dat bij de BBL $79 \%$ van de schoolverlaters te den is over de hulp die ze in de opleiding hebhen gekregen bij de keuze van de volgopleiding of een beroep. Dit geldt zowel voor schoolverlaters van niveau $1 / 2$ voor schoolvertaters van niveau 3/4. Afgestudeerden van het $\mathrm{HBO}$ en het $\mathrm{WO}$ 
Figuur 1.2

Percentage schoolverlaters dat tevreden is over de hulp bij] de keuze van de vervolgopleiding of het beroep per onderwijssoort

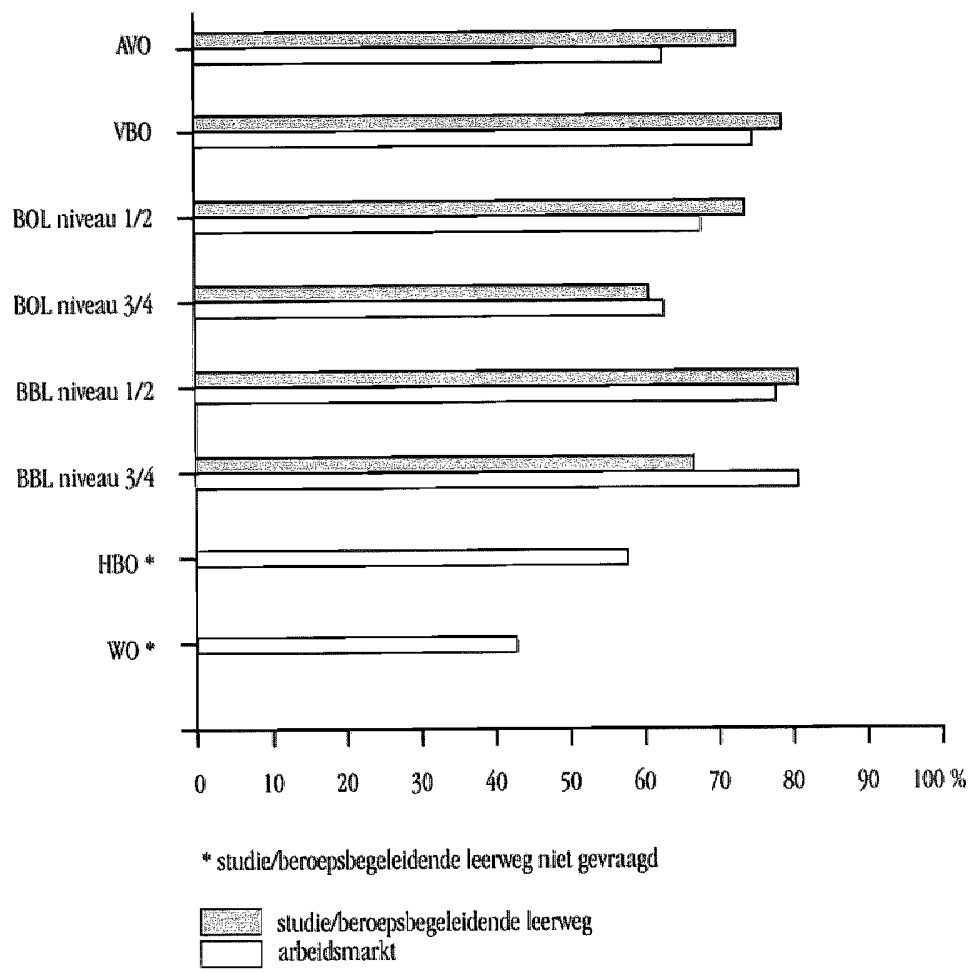

gemiddeld genomen minder vaak tevreden over de hulp die ze hehben gekregen bij ck: keuze van een beroep. Van de afgestudeerden van het HBO en het WO zegl respecticvelijk $60 \%$ en $46 \%$ tevreden te zijn over deze hulp.

\section{$1.2 \mathrm{Kwalificerende} \mathrm{vervolgtrajecten}$}

In deze paragraaf wordt ingegaan op de gediplomeerde schoolverlaters die hebl) $x \cdot n$ gekozen voor een kwalificerend vervolgtraject. We bekijken eerst in welke opleidingen verder lerende schoolverlaters het onderwijs voortzenten. Daarna worden enkele aspecten van de aansluiting tussen de gevolgcle opleiding en de vervolgopleiding besproken. Onder verder lerende schoolverlaters verstaan we zowel degenen die de stuclie vervolgen in een volledige dagopleiding als degenen die werken en leren combineren Aanvullende scholing in de vorm van cursussen en dergelijke bliff hier buiten beschouwing. 


\section{Keuze van de vervolgopleiding}

Figuur 1.3 geeft een overzicht van de kwalificerende vervolgtrajecten van gedipl meerde schoolverlaters. De figuur vermeldt per onderwijssoort het aandeel gedipl meerde schoolverlaters dat naar een kwalificerend vervolgtraject is gegaan. Daarbij zi de onderwijssoorten weergegeven waarin verder lerende schoolverlaters het onderw vervolgen. In figuur 1.3 zijn alléén kwalificerende vervolgtrajecten met een aandeel va ten minste 5\% opgenomen (voor de overige percentages zie tabel A2.1 van Statistische $\mathbb{B i j l a g e )}$. Bij de BOL en de BBL zijn de niveaus $1 / 2$ en $3 / 4$ samengevoegd

Uit figuur 1.3 blijkt dat het merendeel van de AVO-schoolverlaters doorstroomt naar e vervolgopleiding. Schoolverlaters van het MAVO kiezen vaak voor een vervolgopl ding in de BOL, schoolverlaters van het HAVO gaan vaak verder studeren in het $\mathrm{HE}$ en de meerderheid van de schoolverlaters van het VWO kiest voor het WO. Daarna is $20 \%$ van de schoolverlaters van het VWO verder gaan studeren in het $\mathrm{HB}$ Overigens hebben bij het MAVO, het HAVO en het VWO respectievelijk 12\%, $13 \%$ $16 \%$ van de schoolverlaters niet gekozen voor een kwalificerend vervolgtraject. merendeel van de VBO-schoolverlaters gaat na het behalen van het diploma door na het secundair beroepsonderwijs. Daarbij is de BOL de favoriete vervolgopleiding. de schoolverlaters van het VBO gaat $53 \%$ naar een vervolgopleiding in de $\mathrm{BOL}$ en 2 kiest voor de BBL.

lïgur 1.3

Kwalificerende vervolgtrajecten na het verlaten van de opleiding*

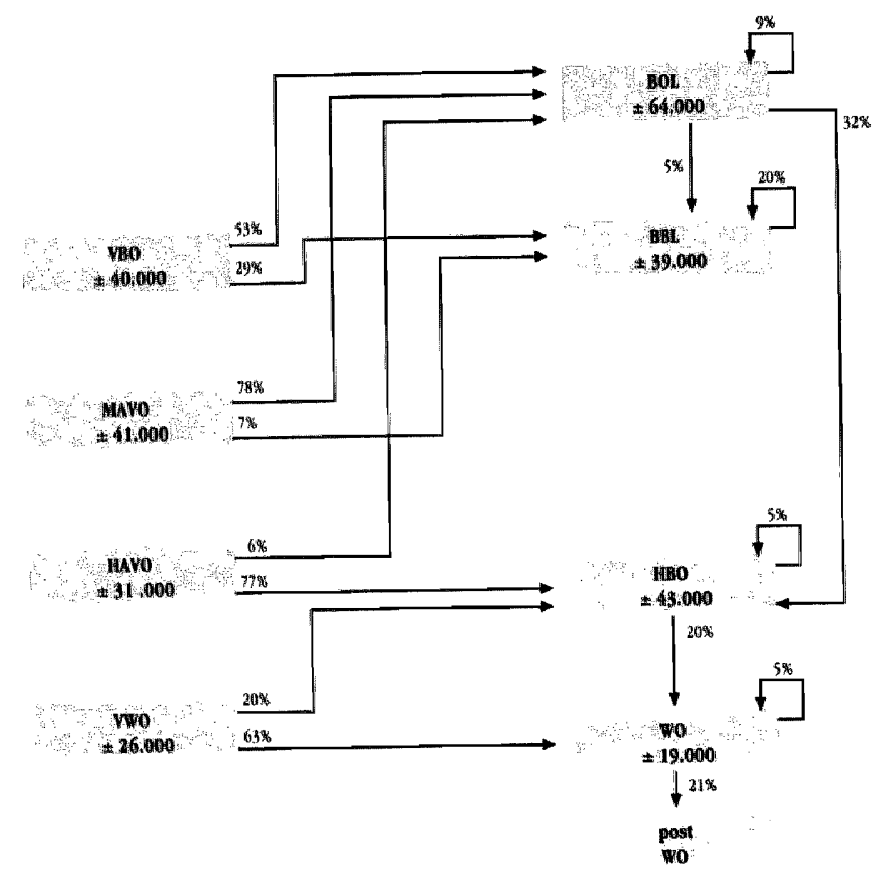

538

$76 \%$

$18 \%$ 
Van de schoolverlaters van de $\mathrm{BOL}$ is bijna de helft naar een kwalificerend vervolgtraject gegaan. Schoolverlaters van de BOL die verder gaan leren stromen door naar het $\mathrm{HBO}$, de BBL of gaan verder in de BOL op een hoger niveau. Van de BBL-schoolverlaters besluit ongeveer eenvierde door te gaan met leren. Het betreft hier met name schoolverlaters van de BBL die op een hoger niveau verder gaan in de BBL. Voor zowel het $\mathrm{HBO}$ als het WO geldt dat $27 \%$ van de afgestudeerden verder gaat in een kwalificerend vervolgtraject. Verder lerende $\mathrm{HBO}$-afgestudeerden gaan vaak doorstuderen in het WO. Het merendeel van de afgestudeerden van het WO dat verder gaat leren volgt een post WO-opleiding (AiO/OiO-plaats, postdoctorale beroepsopleiding, beurspromovendus en ontwerperopleiding).

Figuur 1.4

Doorstroom naar verwante beroepsopleidingen per opleidingssector in het beroepsondenwijs

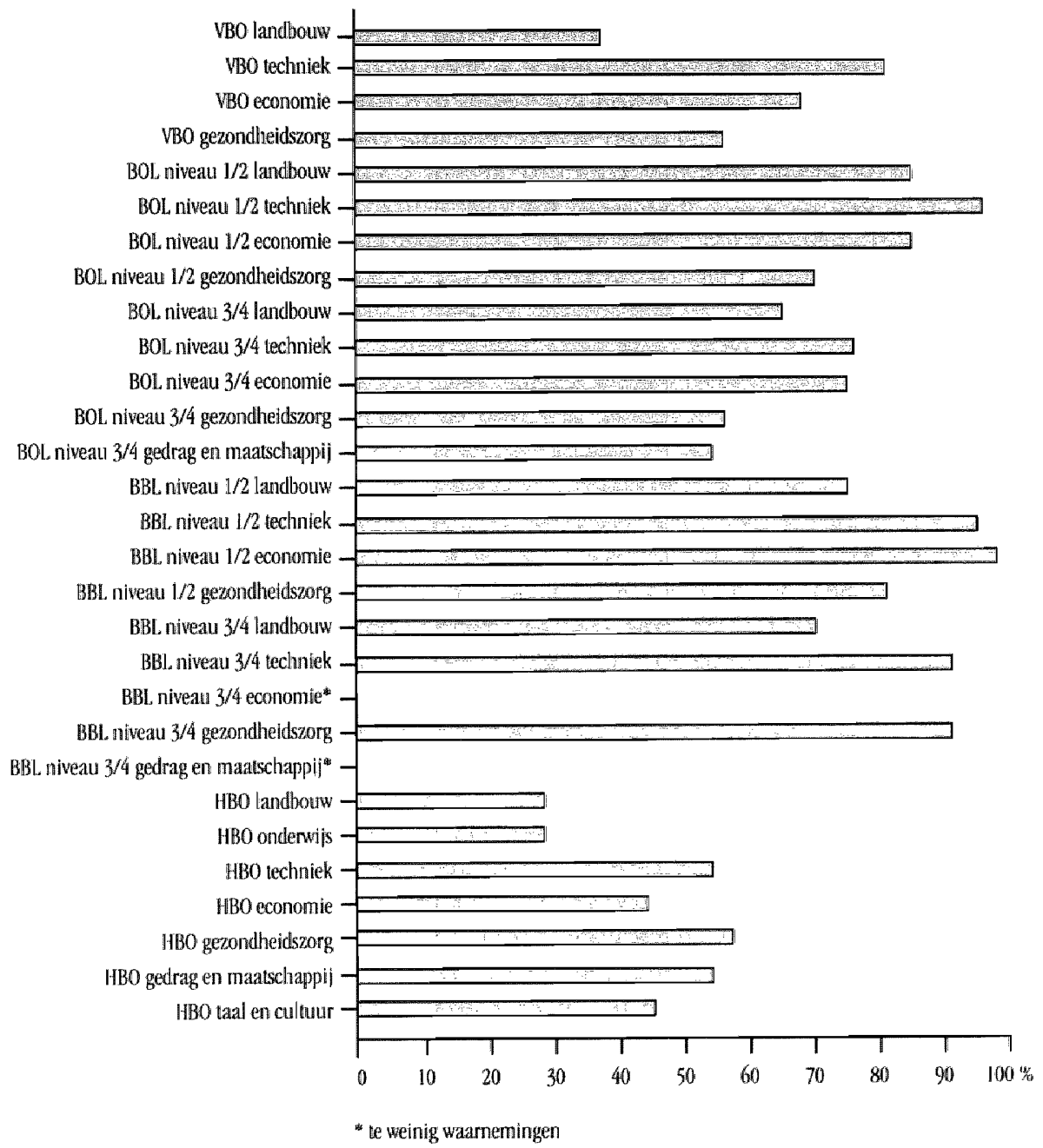


Figuur 1.4 laat zien of schoolverlaters die verder gaan leren hun onderwijsloopbaan dezelfde opleidingsrichting voortzetten. Deze figuur vermeldt het percentage verd lerende schoolverlaters met een verwante vervolgopleiding. Dit percentage is bepaa door voor schoolverlaters in het beroepsonderwijs de afgesloten opleiding te verge ken met de vervolgopleiding. De vervolgopleiding is verwant wanneer de sector van vervolgopleiding gelijk is aan die van de afgesloten opleiding.

Voor het VBO geldt dat vooral schoolverlaters van de sector techniek besluiten verc te gaan leren in een verwante vervolgopleiding. Bij de sectoren VBO economie en VT gezondheidszorg is dit percentage lager. Relatief weinig schoolverlaters van de sec VBO landbouw besluiten verder te gaan leren in een verwante vervolgopleiding. $O$ voor BOL niveau $1 / 2$ en BOL niveau $3 / 4$ geldt dat in de sector techniek het aandeel $v$ der lerendle schoolverlaters dat kiest voor een verwante vervolgopleiding hoog Daarnaast blijkt hier dat schoolverlaters van de sectoren BOL niveau $1 / 2$ gezondhei zorg, BOL niveau 3/4 gezondheidszorg en BOL niveau 3/4 gedrag en maatschappij re tief gezien minder vaak verder gaan leren in een verwante vervolgopleiding. Bij $\mathrm{B}$ niveau $1 / 2$ kiezen bijna alle verder lerende schoolverlaters voor een verwante vervo opleiding. Alleen in de sector gezondheidszorg van BBL niveau $1 / 2$ is het percent: schoolverlaters dat verder gaat leren in een verwante vervolgopleiding iets lager in v gelijking met de andere sectoren. Voor BBL niveau $3 / 4$ geldt dat schoolverlaters van sectoren techniek en gezondheidszorg het vaakst doorgaan in een verwante vervo opleiding (in beide gevallen 92\%). In de sector BBL niveau $3 / 4$ landbouw is dit centage $71 \%$. Ten slotte blijkt dat in het HBO het percentage afgestudeerden dat verder studeren in een verwante vervolgopleiding vrij laag is. In zowel de sector $\mathrm{H}$ landbouw als de secror HBO onderwijs is dit percentage slechts $29 \%$. Voor de over sectoren van het $\mathrm{HBO}$ geldt dat het percentage afgestudeerden dat verder gaat lere een verwante beroepsopleiding varieert tussen de $45 \%$ en $58 \%$.

\section{Aanshuing tussen de afgesloten opleiding en de vervolgopleiding}

In de volgende drie figuren staat de aansluiting tussen de gevolgde opleiding en de volgopleiding centraal. Eerst wordt bekeken welk deel van de verder lerende sch verlaters, achteraf bezien, opnieuw clezelfde opleiding zou volgen. De analyse w uilsluitend uitgevoetd voor verder lerende schoolverlaters van de BOL. de BBL, HBO en het WO. Deze schoolverlaters hebben al een kwalificerend traject achter de en zouden ook natr de arbeidsmarkt kumnen gatan. Het percentage geeft daarom indicatie voor de mate watlin de affgesloten opleiding voor schoolverlaters een go keuze is geweest als vooropleiding. Vervolgens word de uitval van schoolverlate de vervolgopleiding besproken. Tot slot wordt ingegaan op de vraag hoe schoolv ters de amsluiting tussen de afgesloten opleiding en de vervolgopleiding heblen e ren.

Higuur 1.5 vermekt het percentage verder lerende schoolverlaters dat de afgesl opleiding, achteal bezien. opnieuw zou volgen. In totaal zegt $79 \%$ van de verder le de schoolverlaters de afgesloten opleiding, achteraf bezien, opnieuw te willen vol 
Dit geeft aan dat voor veel van de verder lerende schoolverlaters de afgesloten opleiding een goede keuze is geweest. Voor de BOL geldt dat $74 \%$ van de verder lerende schoolverlaters van niveau $1 / 2$ en $80 \%$ van de vercler lerende schoolverlaters van niveau $3 / 4$ opnieuw voor dezelfde opleiding zou kiezen. Tussen de sectoren van de BOL. bestaan wat dit betreft echter verschillen. Bij BOL niveau $1 / 2$ is het percentage verder lerende schoolverlaters dat opnieuw dezelfde opleiding zou kiezen het hoogst in de sector landbouw en relatief laag voor de sector gezondheidszorg. Voor BOL niveau $3 / 4$

Figuur 1.5

Percentage verder lerende schoolverlaters dat de afgesloten opleiding achteraf bezien opnieuw zou volgen per opleidingssector

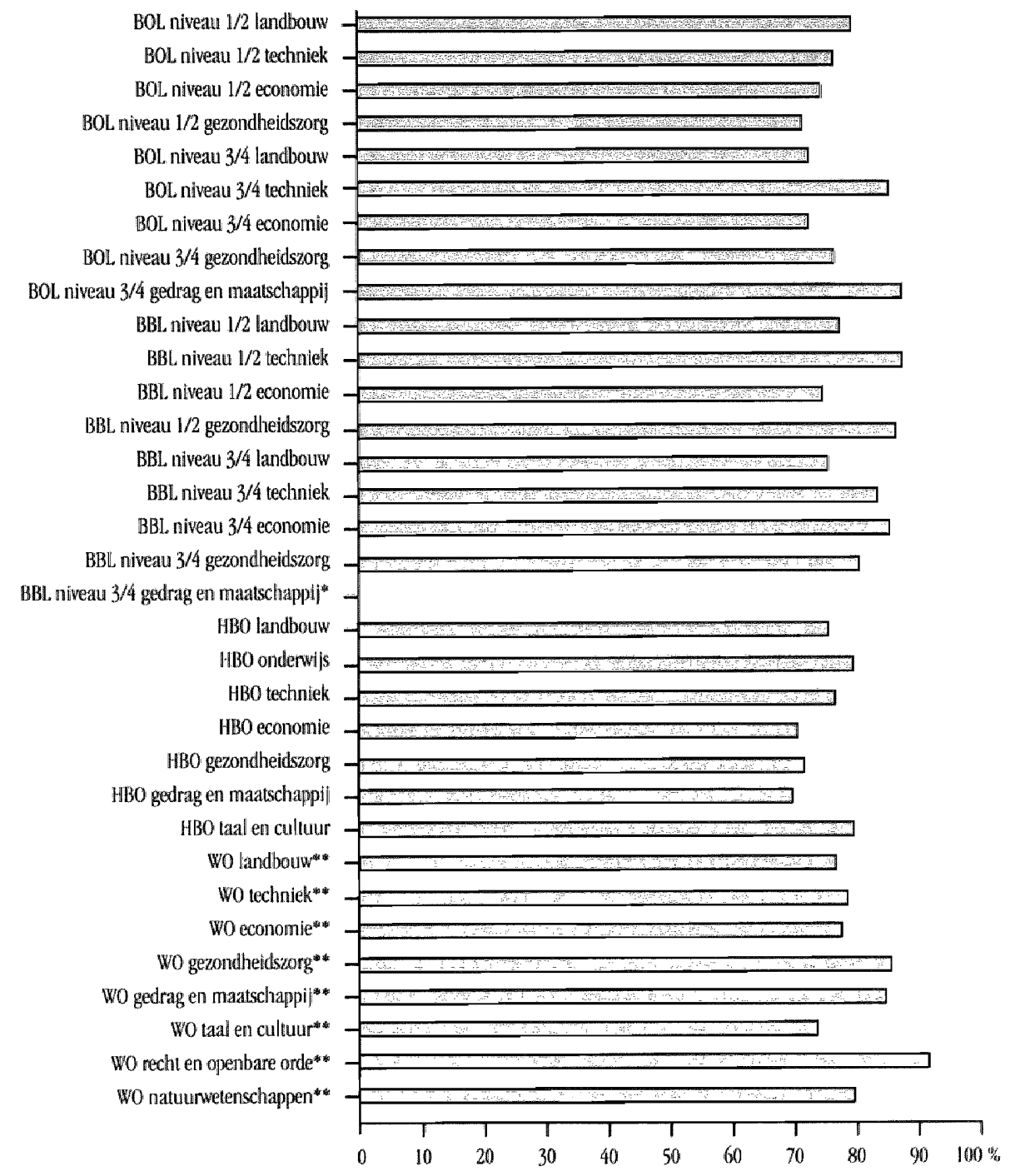




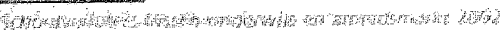

geldt dat in de sectoren gedrag en maatschappij en techniek het percentage verder lerende schoolverlaters dat opnieuw dezelfde opleiding zou kiezen het hoogst is. Dit percentage is lager in de sectoren landbouw en economie. Verder lerende schoolverlaters van de BBL geven gemiddeld genomen het vaakst aan, achteraf bezien, opnieuw voor dezelfde opleiding te kiezen. Van de verder lerende schoolverlaters van BBL niveau $1 / 2$ en BBL niveau $3 / 4$ zegt respectievelijk $85 \%$ en $83 \%$ dezelfde opleiding opnieuw te willen volgen. Bij BBL niveau $1 / 2$ geldt dit met name voor verder lerende schoolverlaters van die sectoren techniek en gezondheidszorg. Bij BBL niveau $3 / 4$ geven verder lerende schoolverlaters van de sectoren economie en techniek relatief vaak aan opnieuw dezelfde opleiding te willen volgen.

Bij het $\mathrm{HBO}$ zegt driekwart van de afgestudeerden die verder gaat studeren dat ze opnieuw dezelfde opleiding zouden kiezen. HBO afgestudeerden van de sectorer onderwijs en taal en cultuur geven het vaakst aan opnieuw voor dezelfde opleiding te kiezen. In vergelijking hiermee ligt bij de sectoren $\mathrm{HBO}$ economie, $\mathrm{HBO}$ gezondheids zorg en $\mathrm{HBO}$ gedrag en maatschappij dit percentage ongeveer $10 \%$ lager. Ten slott geldt voor het WO dat $82 \%$ van de verder studerende academici, achteraf bezien dezelfde opleiding zouden kiezen. Het aandeel academici dat opnieuw voor dezelfd opleiding zou kiezen is het hoogst in de sector WO recht en openbare orde. Daarnaas is dit aandeel ook hoog in de sector WO gezondheidszorg. In het WO zeggen verde studerende academici van de sector taal en cultuur het minst vaak opnieuw dezelfd opleiding te willen volgen.

In figuur 1.6 is het aandeel verder lerende schoolverlaters dat de vervolgopleiding voor tijdig heeft verlaten weergegeven. Het gaat hier om de verder lerende schoolverlater die de vervolgopleiding binnen ongeveer één jaar ongediplomeerd hebben verlaten Het voortijdig verlaten van de vervolgopleiding kan een indicatie zijn voor de mat waarin de afgesloten opleiding aansluit op de vervolgopleiding. Wanneer in eet bepaalde vervolgopleiding de omvang van de uitval van scholieren of studenten groc is, kan dit cluiden op een gebrekkige aansluiting tussen de afgesloten opleiding en d vervolgopleiding. Overigens kunnen ook redenen die niet gerelateerd zijn aan de afge sloten opleiding er toe bijdragen dat schoolverlaters de vervolgopleiding voortijdig ver laten. Het kan bijvoorbeeld voorkomen dat bij schoolverlaters de motivatie ontbreek om verder te gaan leren of dat schoolverlaters de verkeerde studiekeuze hebbe gemakkt en liever verder gaan leren in een andere vervolgopleiding.

In totaal heeft $13 \%$ van de verder lerende schoolverlaters de vervolgopleiding voortijdi verlaten. Van de verder lerende schoolverlaters van het HAVO is $17 \%$ voortijdig gestop met de vervolgopleiding. Voor BOL niveau $1 / 2$ geldt dat gemiddeld $15 \%$ van de verde lerende schoolverlaters de vervolgopleiding voortijdig heeft verlaten. Dit percentage met name hoog in de sectoren gezondheidszorg en techniek. Voor BOL niveau $3 / 4$ gelc dat gemiddeld genomen $13 \%$ van de verder lerende schoolverlaters uitvalt in de ve volgopleiding. De verschillen tussen sectoren zijn bij BOL niveau 3/4 wat dit betreft $v_{1}$ gering.

Bij de BBL is het percentage verder lerende schoolverlaters dat de vervolgopleidin voortidig verlaat gemiddeld genomen lager dan bij de andere onderwijssoorten. Vou 
tijdig verlaat; bij BBL niveau $3 / 4$ is dit $8 \%$. Verder blijkt dat bij de BBL zowel op niveau $1 / 2$ als op niveau $3 / 4$ de uitval het laagst is in de sector techniek. Bij het $\mathrm{HBO}$ bedraagt het percentage voortijdig schoolverlaters $15 \%$. In de sector HBO landbouw is de uitval vrij laag, terwijl deze in de sectoren $\mathrm{HBO}$ onderwijs en $\mathrm{HBO}$ gedrag en maatschappij relatief hoog is. In het WO is het percentage uitvallers daarentegen het hoogst in de sector landbouw. Ook de sector WO taal en cultuur kent relatief veel uitvallers. Voor het

Figuur 1.6

Percentage van de verder lerende schoolverlaters dat de vervolgopleiding voortijdig heeft verlaten (uitvallers) en het percentage van deze uitvallers dat een andere opleiding is gaan volgen (studiewisselaars) naar sector vervolgopleiding

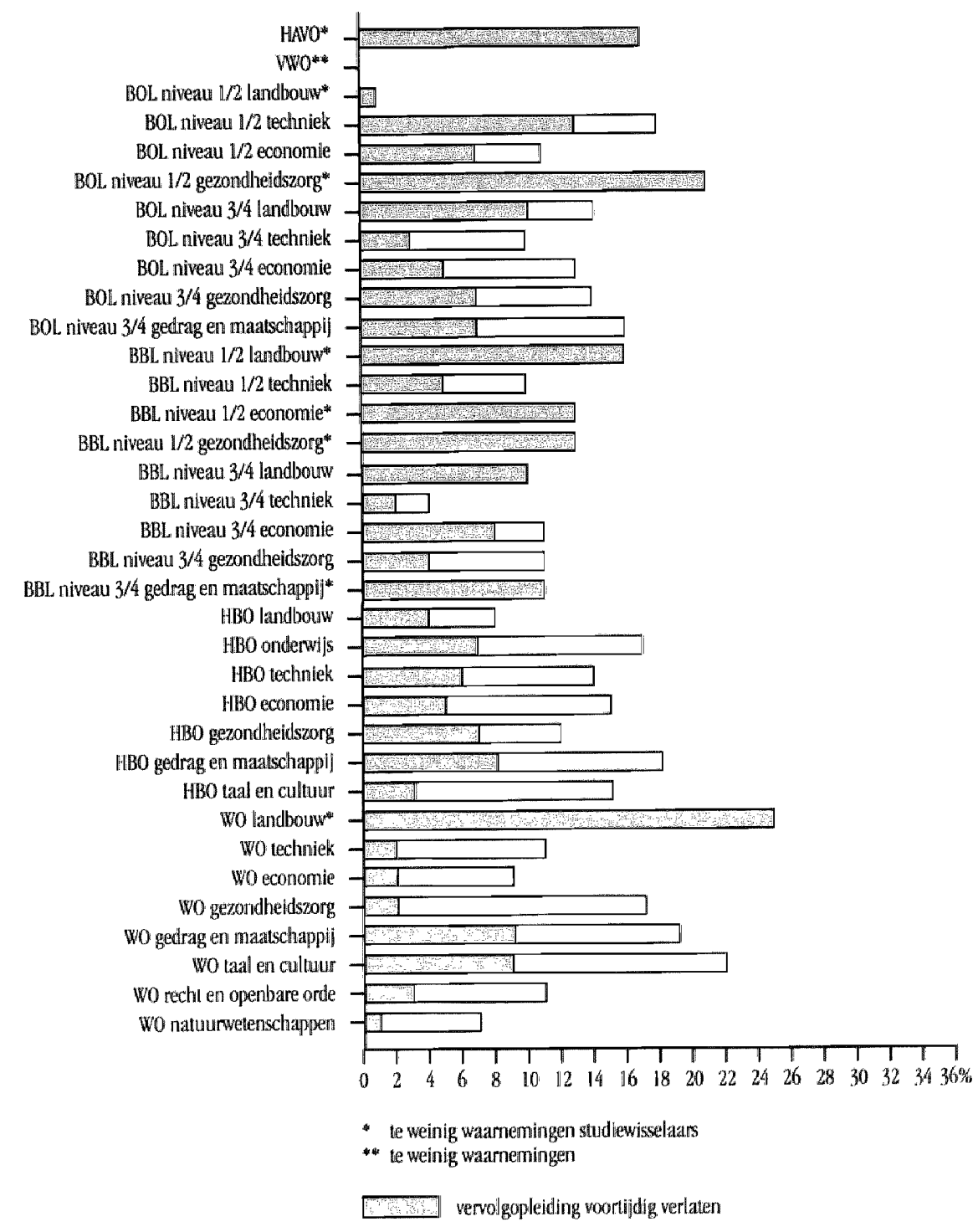


WO geldt dat in de sector natuurwetenschappen het percentage voortijdig schoolve ters het laagst is.

Het verlaten van de opleiding zonder dat het diploma is behaald betekent niet altijd er een punt wordt gezet achter de onderwijsloopbaan. Zoals eerder is gezegd, kan voorkomen dat schoolverlaters een verkeerde studiekeuze hebben gemaakt en bes ten van studie te wisselen. In figuur 1.6 is - naast de voortijdige uitval van schoolve ters in de vervolgopleiding - ook het percentage schoolverlaters dat van studi gewisseld vermeld. Het betreft het percentage schoolverlaters dat na het voortijdig laten van de vervolgopleiding verder gaat leren in een andere opleiding.

Meer dan cle helft van de schoolverlaters die de opleiding voortijdig hebben verlate van studie gewisseld en verder gegaan in een andere vervolgopleiding. De ove voortijdig schoolverlaters hebben een andere bestemming. Het percentage studier selaars is vrij laag bij BOL niveau $1 / 2$ en bij BBL niveau $3 / 4$. Voor BBL niveau $3 / 4 \mathrm{~g}$ dat vooral bij de sectoren landbouw en economie weinig schoolverlaters die de volgopleiding voortijdig staken van studie wisselen. Voor BOL niveau 3/4 geldt dat van de uitvallers heeft besloten een andere vervolgopleiding te gaan doen. Met na veel uitvallers van de sector BOL niveau $3 / 4$ techniek zijn van studie gewisseld. Bij HBO en het WO is het aandeel studiewisselaars gemiddeld het hoogst. Tussen de schillende sectoren binnen het HBO en het WO zijn vrij weinig verschillen in het deel studiewisselaars. Alleen voor de sector HBO gezondheidszorg geldt dat aandeel studiewisselaars relatief laag is vergeleken met andere sectoren in het HBO het WO geldt dit voor de sector WO taal en cultuur.

Tot slot wordt bekeken op welke wijze verder lerende schoolverlaters de aanslui tussen de afgesloten opleiding en de vervolgopleiding hebben ervaren. In figuur 1 dartoe het percentage verder lerende schoolverlaters vermeld dat de aansluiting sen de afgesloten opleiding en de vervolgopleiding voldoende tot goed vindt. In c figuur is een onderscheid gemalkt tussen schoolverlaters die een volledige dagor ding zijn gatan doen en schoolverlaters die werken en leren combineren via de BBL. merendeel van de verder lerende schoolverlaters geeft atan tevreden te zijn over de : sluiting tussen de gevolgcle opleiding en de vervolgopleiding. Van de verder lere schoolverkaters die een volledige dagopleiding zijn gaan doen zegt $85 \%$ dat de verv opleiding voldoende tot goed ansluit op de afgesloten opleiding. Voor de school laters die verder gatan in de $\mathrm{BBL}$ is dit $88 \%$.

Veel van de schoolverlaters van het AVO en het VBO zijn tevreden over de aanslui Iussen de gevolgde opleiding en de vervolgopleiding. Ten minste $80 \%$ van de AVO $\mathrm{V} 13 \mathrm{O}$-schoolvetlaters die verder gatan leren zegt dat de aansluiting tussen de afgeslo opleiding en de vervolgopleiding voldoende tot goed is. Hierbij bestaan weinig schillen tussen schoolverlaters van het MAVO, het HAVO en het VWO. Binnen het zeggen schoolverlaters van de sector gezondheidszorg het valakst dat de aansluiting de vervolgopleiding voldoende tol goed is. Voor BOL niveau $1 / 2$ geldt ook dat sch verlaters over het algemeen tevreden zijn over de aansluiting tussen de afgesloten op ding en de vervolgopleiding. Met name schoolverlaters van de sector $\mathrm{BOL}$ niveau gezondheidszorg geven vaak aan dat de aansluiting met de vervolgopleiding vold 
economie dat de aansluiting met de BBL voldoende tot goed is. Van de schoolverlaters van de sector BOL niveau $1 / 2$ economie die kiezen voor een volledige dagopleiding geeft 'slechts' $84 \%$ aan dat deze aansluiting voldoende tot goed is.

Bij BOL niveau 3/4 valt op dat schoolverlaters van de sector techniek die verder gaan in de BBL bijna allemaal tevreden zijn over de aansluiting tussen de afgesloten opleiding en de vervolgopleiding. Opvallend hierbij is her verschil met schoolverlaters van de sector BOL niveau 3/4 techniek die verder gaan leren in een volledige dagopleiding. Deze zijn minder vaak tevreden over de aansluiting met de vervolgopleiding. Voor her HBO geldt dat er weinig verschillen bestaan tussen sectoren in het percentage afgestudeer-

Figuur 1.7

Percentage van de verder lerende schoolverlaters dat de aansluiting tussen de gevolgde opleiding en de vervolgopleiding voldoende of goed vindt per opleidingssector

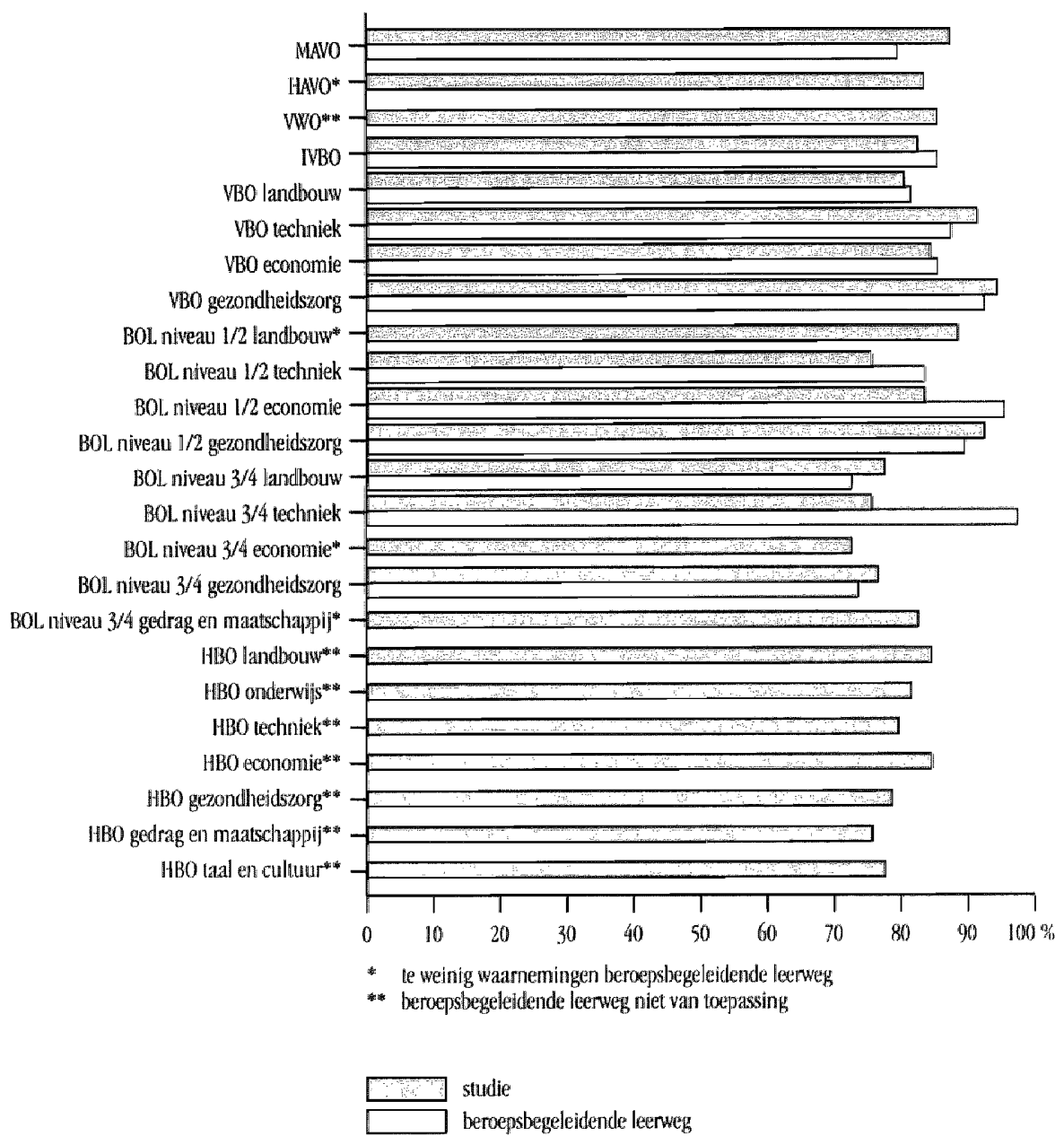


den dat tevreden is over de aansluiting tussen de afgesloten opleiding en de vervo opleiding. Dit percentage ligt bij de verschillende sectoren van het $\mathrm{HBO}$ rond de 80

\subsection{Intrede op de arbeidsmarkt}

Deze paragraaf gaat in op de arbeidsmarktintrede van gediplomeercle schoolverlat De arbeidsmarktintrede wordt aan de hand van twee dimensies in beeld gebrac 'werkgelegenheid en werkzekerheid' en 'kwaliteit van het werk'. De afgelopen jare de situatie op de arbeidsmarkt over het algemeen gunstig geweest voor schoolverlat Dit is tot uiting gekomen in een flinke toename van het werkgelegenheidsperspec en de werkzekerheid van gediplomeerde schoolverlaters en een verbetering van kwaliteit van het werk. Op dit moment lijkt de periode van hoogconjunctuur Nederland voorbij, waardoor de situatie op de arbeidsmarkt minder gunstig kan den voor schoolverlaters. Echter, de gegevens in deze rapportage hebben betrekk op schoolverlaters die in het schooljaar 2000/2001 het diploma hebben beha: Waarschijnlijk hebben deze schoolverlaters nog niet zoveel te maken gekregen me minder gunstige economische omstandigheden tijdens het moment van intrede op arbeidsmarkt.

De onderzoeksgroep in deze paragraaf bestaat uit gediplomeercle schoolverlaters op het moment van ondervraging tot de beroepsbevolking worden gerekend en tevens aangeven dat hun maatschappelijke positie niet scholier of student is.

\section{Werkgelegenbeid}

Figuur 1.8 laat eerst zien welk deel van de schoolverlaters zich aanbiedt op de arbe markt. In totaal heeft $53 \%$ van de gediplomeerde schoolverlaters anderhalf jaar na behalen van het diploma de arbeidsmarkt betreden. Uit figuur 1.8 blijkt dat $20 \%$ vat schoolverlaters van het MAVO zich aanbiedt op de arbeidsmarkt. Bij het HAVO en VWO is dit respectievelijk $10 \%$ en 5\%. Dit percentage is relatief hoog voor schoolv ters van het MAVO, ondat deze vaker clan schoolverlaters van het HAVO en het $V$ kierzen voor de BBI.. Bijna de helft van de MAVO-schoolverlaters die zich aanbiede de artheidsmarkt heeft op het moment van ondervragen een leer-arbeidsovereenko Voor het VBO geldt dat relatief veel schoolverlaters van het IVBO en de sector tech zich atunbieden op de arbeidsmarkt, terwiil dit percentage bij de sectoren economi gezondheidszorg duidelijk lager ligt. Voor de sector VBO techniek geldt ook dat schoolverlaters die zich anbieden op de arbeidsmarkt een leer-arbeidsovereenk hebhen. Voor schoolverlater's van het IVBO geld dit echter niet. Bij BOL niveau biedt bijna $80 \%$ van de schoolverlaters van de sectoren landbouw en techniek zich op de arbeidsmarkt. Bij de sectoren economie en gezondheidszorg van BOL niveat ligt dit percentage een stuk lager.

Voor BOL niveau $3 / 4$ geldr dat $78 \%$ van de schoolverlaters van de sector gezondh zorg zich aanbiedt op cle arbeidsmarkt. Bij de sector BOL niveau $3 / 4$ landbouw percentage $67 \%$ en voor cle overige sectoren van BOL niveau $3 / 4$ geld dat ongeve helft van de schoolverlaters zich atanbiedt op de arbeidsmarkt. Voor de BBL, het en het WO geldt dit het merendeel van de schoolverlaters de arbeidsmarkt betreec 
Figuur 1.8

Percentage gediplomeerde schoolverlaters dat zich aanbiedt op de arbeidsmarkt en werkloosheidspercentage onder gediplomeerde schoolverlaters per opleidingssector

$\%$ aanbieders

MAVO
HAVO
WWO
IVBO

VBO landbouw

VBO techniek

VBO economie

KBO gezondheidszorg BOL nivean $1 / 2$ landbouw

BOL niveau $1 / 2$ techniek

BOL. niveau $1 / 2$ economie

BOL niveau $1 / 2$ gezondheidszorg

BOL niveau $3 / 4$ landbouw

BOL rivenu $3 / 4$ techniek

BOL niveau 3/4 economie

$\mathrm{BOL}$ niveau $3 / 4$ gezondheidszorg BOL. niveau 3/4 gedrag en maatschappii

BBL niveau $1 / 2$ landbouw -

BBL niveau $1 / 2$ techniek

BBL, niveau $1 / 2$ economie

BBL niveau $1 / 2$ gezondheidszorg

BBL niveau 3/4 landbouw

BBL niveau 3/4 techniek

BBL niveau $3 / 4$ economie

BBL niveau $3 / 4$ gezondheidszorg -

BBL niveau $3 / 4$ gedrag en maatschappi] -

HBO landbouw

HBO onderwijs

HBO techniek

HBO economie -

$\mathrm{HBO}$ gezondhetdszorg

HBO gedrag en matschappi|

HBO taal en cultur

wo landbouw

wo lechniek

Wo economie

Wo gezondheidszorg

W0 gedrag en maasschappij

wo taal en cultuur

Wo recht en openbare orde

Wo natuurwetenschappen

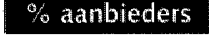

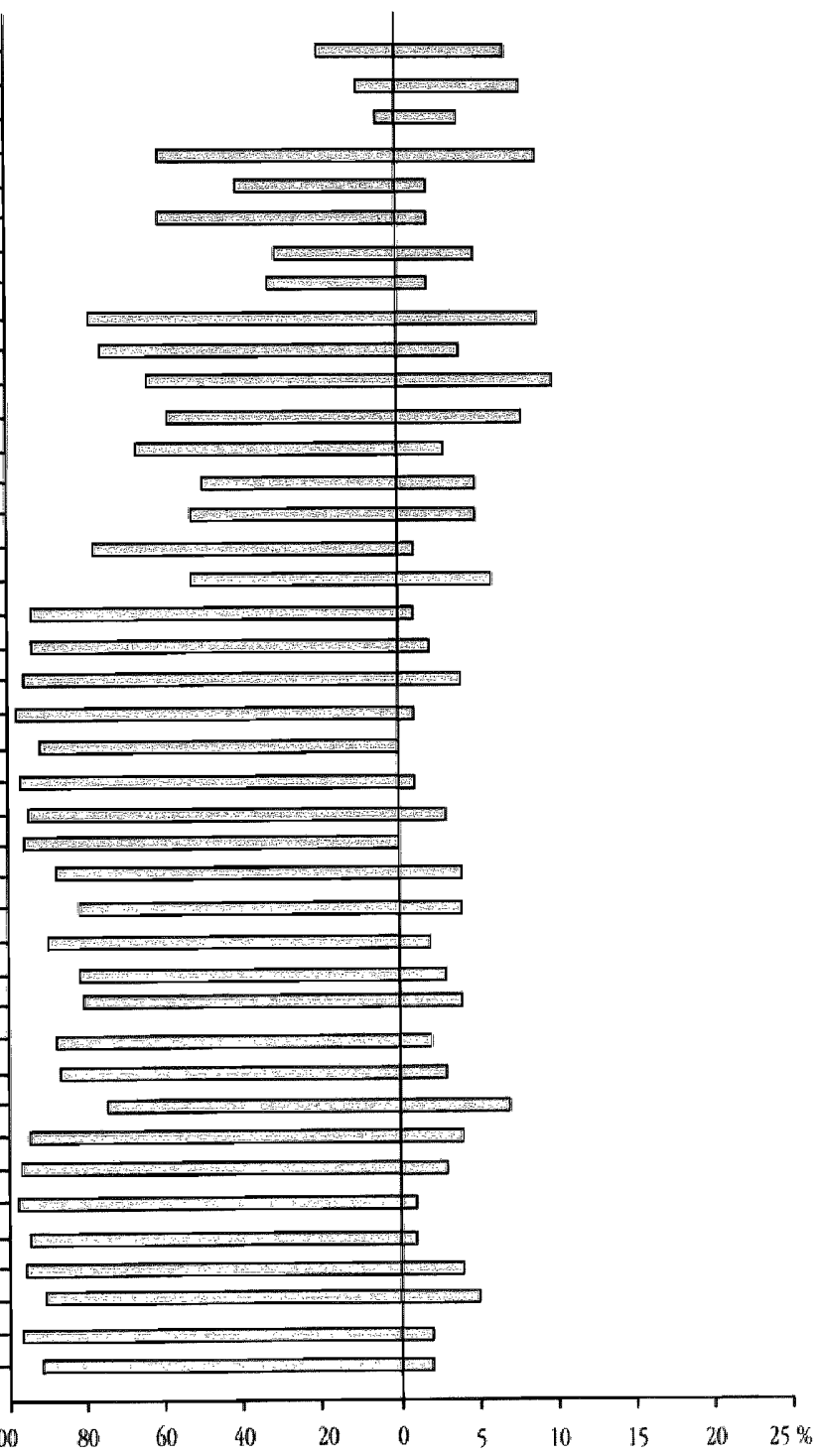

schoolverlaters dat zich aanbiedt op de arbeidsmarkt zijn gering bij de 13BL, het HBO en het WO. Alleen bij de sector HBO taal en cultuur ligi het aandeel afgestudeerden dat zich op de arbeidsmarkt heeft aangeboden beneden de $80 \%$.

In figuur 1.8 is ook hel werkloosheidspercentage voor het jaar 2002 weergegeven (zic 
den dat tevreden is over de aansluiting tussen de afgesloten opleiding en de vervolg opleiding. Dit percentage ligt bij de verschillende sectoren van het $\mathrm{HBO}$ rond de $80 \%$

\subsection{Intrede op de arbeidsmarkt}

Deze paragraaf gaat in op de arbeidsmarktintrede van gediplomeerde schoolverlater De arbeidsmarktintrede wordt aan de hand van twee dimensies in beeld gebrach 'werkgelegenheid en werkzekerheid' en 'kwaliteit van het werk'. De afgelopen jaren de situatie op de arbeidsmarkt over het algemeen gunstig geweest voor schoolverlaters Dit is tot uiting gekomen in een flinke toename van het werkgelegenheidsperspectio en de werkzekerheid van gediplomeerde schoolverlaters en een verbetering van d kwaliteit van het werk. Op dit moment lijkt de periode van hoogconjunctuur i Nederland voorbij, waardoor de situatie op de arbeidsmarkt minder gunstig kan wor den voor schoolverlaters. Echter, de gegevens in deze rapportage hebben betrekkin op schoolverlaters die in het schooljaar 2000/2001 het diploma hebben behaalc Waarschijnlijk hebben deze schoolverlaters nog niet zoveel te maken gekregen met d minder gunstige economische omstandigheden tijdens het moment van intrede op d arbeidsmarkt.

De onderzoeksgroep in deze paragraaf bestaat uit gediplomeerde schoolverlaters di op het moment van ondervraging tot de beroepsbevolking worden gerekend en di tevens aangeven dat hun maatschappelijke positie niet scholier of student is.

\section{Werkgelegenbeid}

Figuur 1.8 laat eerst zien welk deel van de schoolverlaters zich aanbiedt op de arbeid markt. In totaal heeft $53 \%$ van de gediplomeerde schoolverlaters anderhalf jaar na he behalen van het diploma de arbeidsmarkt betreden. Uit figuur 1.8 blijkt dat $20 \%$ van d schoolverlaters van het MAVO zich aanbiedt op de arbeidsmarkt. Bij het HAVO en he VWO is dit respectievelijk $10 \%$ en $5 \%$. Dit percentage is relatief hoog voor schoolverla ters van het MAVO, omdat deze vaker dan schoolverlaters van het HAVO en het VW kiezen voor de BBL. Bijna de helft van de MAVO-schoolverlaters die zich aanbieden o de arbeidsmarkt heeft op het moment van ondervragen een leer-arbeidsovereenkoms Voor het VBO geld dat relatief veel schoolverlaters van het IVBO en de sector technie zich atnhieden op de arbeidsmarkt, terwijl dit percentage bij de sectoren economie $e$ gezondlheidszorg duidelijk lager ligt. Voor de sector VBO techniek geldt ook dat ve schoolverlaters die zich aanbieden op de arbeidsmarkt een leer-arbeidsovereenkom hebben. Voor schoolverlaters van het IVBO geldt dit echter niet. Bij BOL, niveau $1 /$ biedt bijna $80 \%$ van de schoolverlaters van de sectoren landbouw en techniek zich aa op de arbeidsmarkt. Bij de sectoren economite en gezondheidszorg van BOL niveau $1 /$ ligt dit percentage een stuk lager.

Voor BOL niveau $3 / 4$ geldt dat $78 \%$ van de schoolverlaters van de sector gezondheid zorg zich anbied op de arbeidsmarkt. Bij de sector BOL niveau 3/4 landbouw is d percentage $67 \%$ en voor de overige sectoren van BOL niveau $3 / 4$ geldt dat ongeveer d helft van de schoolverlaters zich aanbiedt op de arbeidsmarkt. Voor de BBL, het HBO en het WO geldt dat het merendeel van de schoolverlaters de arbeidsmarkı betreed. B de BBBL en het wO ligt hel atundeel schooverlaters dat zich aanbiedt op de arbeidsmart 
Figuur 1.8

Percentage gediplomeerde schoolverlaters dat zich aanbiedt op de arbeidsmarkt en werkloosheidspercentage onder gediplomeerde schoolverlaters per opleidingssector

VBO gezondheidszorg

BOL niveau $1 / 2$ landbouw

BOL niveau $1 / 2$ tochniek

BOL niveau $1 / 2$ economie

BOL niveau $1 / 2$ gezondheidszorg

BOL niveau $3 / 4$ landbouw

BOL niveau $3 / 4$ techniek

BOL niveau $3 / 4$ economie

BOL niveau $3 / 4$ gezondheidszorg BOL niveau $3 / 4$ gedrag en maatschappii

BBL niveau $1 / 2$ landbouw

BBL. niveau $1 / 2$ teclniek

BBL. niveaul $1 / 2$ economie

BBL niveau $1 / 2$ gezondheidszorg

BBL niveau $3 / 4$ landbouw

BBL niveau $3 / 4$ technick

BBL niveau 3/4 economie

BBL. niveau 3/4 gezondheidszorg BBL niveau $3 / 4$ gedrag en maatschappij

YBO

$\mathrm{HBO}$ onderwifs

HBO techniek

HBO economie

HBO gezondheidszorg

HBO gedrag en matalschappi

HBO taal en cultuu

wo landbouw

WO techniek

wo economie

wo gezondheidszorg

wo gedrag en maatschappij

Wo taal en cultuur

wo recht en openbare orde

Wo natuurwetensclappen

100
$\%$ anbieders

$\%$ werkloos

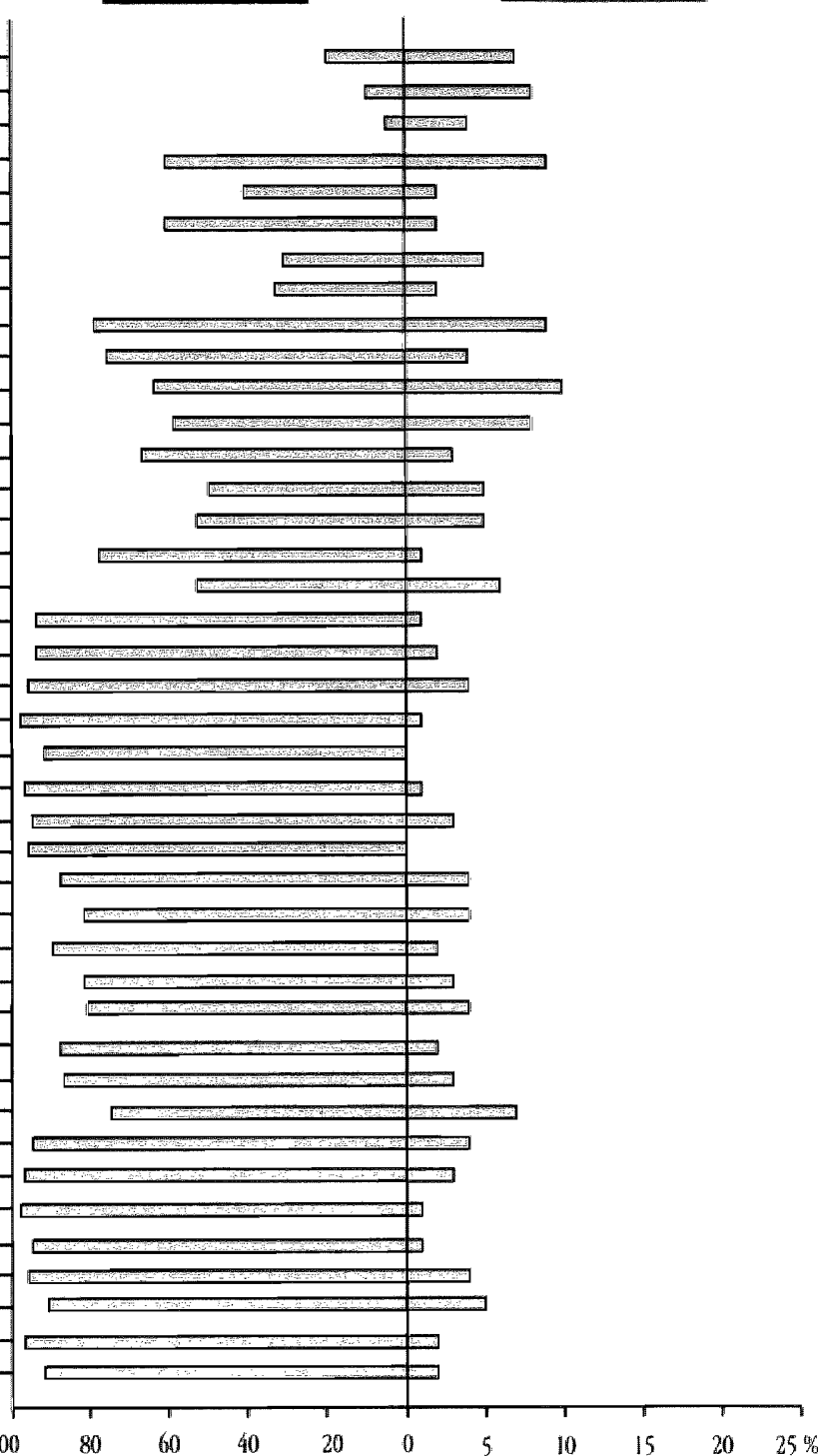

schoolverlaters dat zich aanbiedt op de arbeidsmarkt zijn gering bij de BBLL, hel HBO en het WO. Alleen bij de sector HBO taal en cultur ligt het andeel afgestudeerden dat zich op de arbeidsmarkt heeft aangeboden beneden de $80 \%$.

In figuur 1.8 is ook het werkloosheidspercentage voor het jaar 2002 weergegeven (xic 
arbeidsmarkt is het percentage dat tot de werklloze beroepsbevolking wordt gerekend vermeld. In totaal is $3 \%$ van de gediplomeerde schoolverlaters werkloos. Dit percenta ge is gelijk aan het jaar 2001. Wel blijkt dat in vergelijking met het jaar 2001 het werk loosheidspercentage is gestegen voor schoolverlaters van het AVO en de BOL, maa gedaald voor schoolverlaters van het VBO. Voor het AVO geldt dat het werkloosheids percentage is gestegen van $5 \%$ in 2001 naar $7 \%$ in 2002 . Hier geldt dat dit percentage alleen is toegenomen voor HAVO- en VWO-schoolverlaters. Bij BOL niveau $1 / 2$ is he percentage werklozen gestegen van $7 \%$ in 2001 naar $8 \% 2002$, en bij BOL niveau $3 / 4$ van $2 \%$ naar $4 \%$. Voor BOL niveau $1 / 2$ geldt dat vooral in de sector landbouw he werkloosheidspercentage is toegenomen. Bij $\mathrm{BOL}$ niveau $3 / 4$ is bij alle sectoren (me uitzondering van de sector landbouw) het percentage werklozen gestegen. Bij het VBC is het percentage schoolverlaters dat tot de werkloze beroepsbevolking wordt gerekend gedaald van $6 \%$ in 2001 naar $3 \%$ in 2002 . Binnen het VBO is dit percentage voora gedaald in de sectoren landbouw en economie.

Voor de overige onderwijssoorten geldt dat het werkloosheidspercentage gelijk is ge bleven in vergelijking met afgelopen jaar. Slechts een zeer beperkt deel van de gedi plomeerde schoolverlaters van de BBL, het $\mathrm{HBO}$ en het $\mathrm{WO}$ is werkloos anderhalf jaa na het behalen van het diploma. Het werkloosheidspercentage voor deze onderwijs soorten is gemiddeld $3 \%$ of lager. Alleen in de sector HBO taal en cultuur is het werk loosheidspercentage relatief gezien hoog $(7 \%)$. Voor afgestudeerden van de sector $\mathrm{HBC}$ tal en cultuur client echter rekening te worden gehouden met de situatie van kunste naars op het moment van ondervragen. Het is mogelijk dat een kunstenaar op he moment van ondervragen aan het werk is en op een later tijdstip een inkomen gene reert, bijvoorbeeld door bezig te zijn met het maken van kunstwerken die op een late tijdstip worden verkocht. Dit is in lijn met het feit dat slechts $5 \%$ van alle afgestudeer den HBO taal en cultuur zichzelf als werkloos ziet (zie tabel A1.3 van de Statistisch Bijlage).

Het merendeel van de schoolverlaters die de arbeidsmarkt betreden heeft betaald werl anderlall jaar na het verlaten van de opleiding. Dit betekent echter niet dat gediplo meercle schoolvertaters na het verlaten van de opleiding direct al een baan hebber gevonden. Het kan gebeuren dat voor schoolverlaters periodes van werkloosheid et betalkl werk elkatr alwisselen. Figuur 1.9 laat zien hoe lang schoolverlaters tijdens d. intredeperiode - de periode na het verlaten van de opleiding tor en met het momen van ondervaraen - werkloos zijn geweest. vermeld is hel percentage gediplomeerd schoolverlaters dat vier matanden of langer werkloos is geweest en het percentage ged plomeerces schoolverlaters dat in zijn geheel niet werkloos is geweest.

Ilit liguur 1.9 blijkt dan de arbeidsmarkintrede van schoolverlaters over het algemeet soepel is verlopen. In tolat is slechts $5 \%$ van de schoolverlaters die zich hebben aan geloxten op de arleichmarki vier maanden of langer werkloos geweest. Daarnaast $86 \%$ van de schoolverlaters in zijn geheel niet werkloos geweest na het verlaten wan d. opleiding. Wel blijkt dat voor afgestudeerden van het $\mathrm{HBO}$ en het WO de intredewet keloosheid is loegenomen in vergelijking met vorig jaar. Van de HBO-afgestudeerden in totalal $7^{\text {\%o }}$ vier matanden of langer werkloos geweest na het behalen van her diploma Dit percentage is $2 \%$-punten hoger dan in 2001 . Voor het WO gelde dat in totaal $12 \%$ vat 
Fïguur 1.9

Intredewerkloosheid en percentage gediplomeerde schoolverlaters dat nilet werkloos is geweest sinds het verlaten van de opleiding per opleidingssector

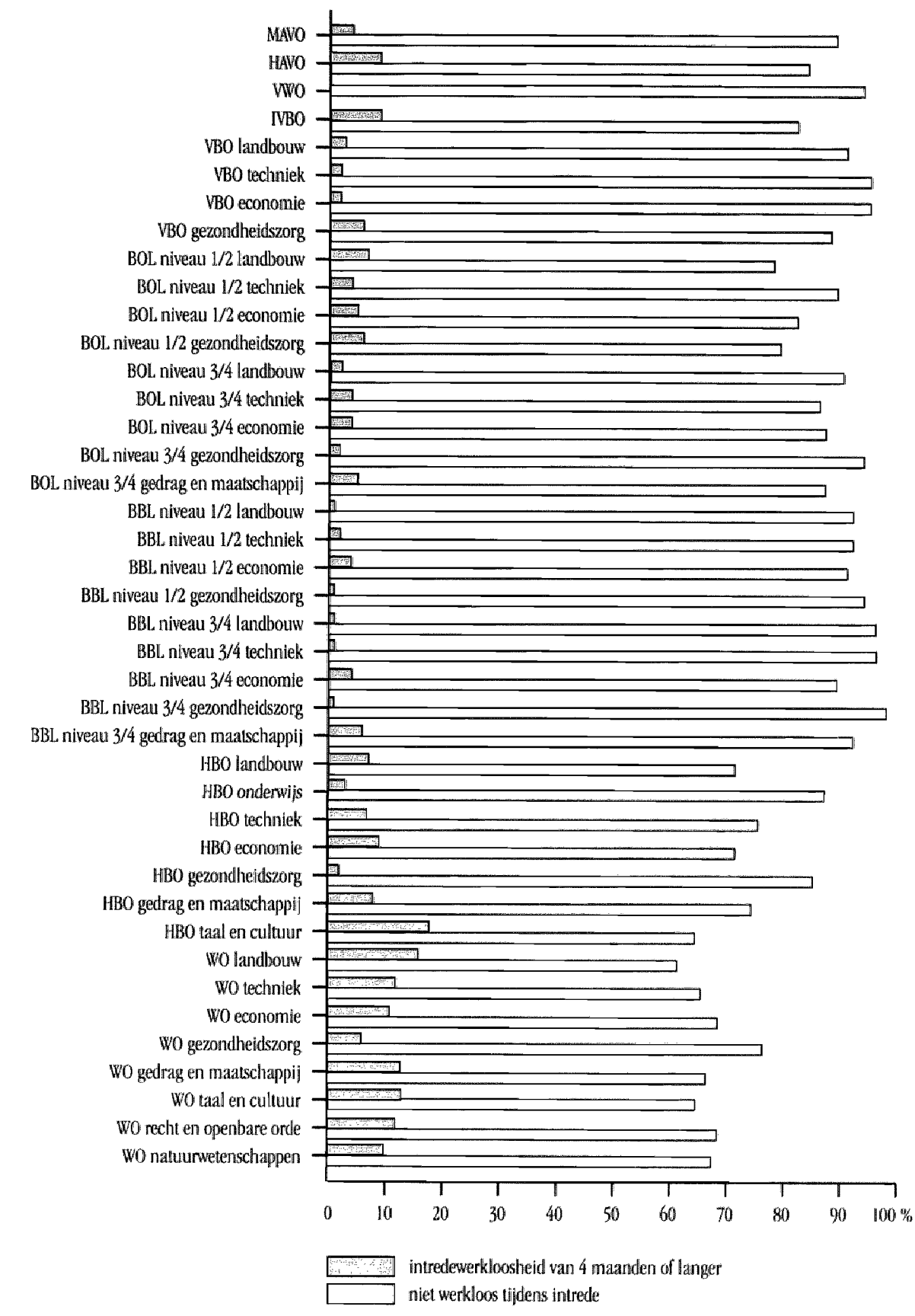


vergelijking met 2001. Deze ciffers lijken er op te wijzen dat hoger opgeleiden lan hebben moeten zoeken naar een geschikte baan dan vorig jaar. Een andere aanwijz hiervoor is dat bij het $\mathrm{HBO}$ en het $\mathrm{WO}$ het percentage afgestudeerden dat niet werkl is geweest tijdens de intredeperiode is afgenomen in vergelijking met 2001. Bij het $\mathrm{H}$ zijn vooral veel afgestudeerden van de sector taal en cultuur vier maanden of lan werkloos geweest. Voor het WO geldt dat bij de sectoren het aandeel afgestudeer dat vier maanden of langer werkloos is geweest varieert tussen de $11 \%$ en $16 \%$. All bij de sector WO gezondheidszorg is dit aandeel met $6 \%$ een stuk lager.

Het aandeel schoolverlaters dat vier maanden of langer werkloos is geweest, is v lager opgeide schoolverlaters ongeveer gelijk aan vorig jaar. Er zijn echter een aa sectoren waar de arbeidsmarktintrede van schoolverlaters iets minder stabiel verlo Bij het HAVO en het IVBO zijn relatief veel schoolverlaters die zich aanbieden of arbeidsmarkt vier maanden of langer werkloos geweest (9\%). Voor het VBO geldt $6 \%$ van de schoolverlaters van de sector gezondheidszorg vier maanden of langer $w$ loos zijn geweest. Bij de andere sectoren van het VBO is dit percentage slechts 2 of Bij de BOL en de BBL verloopt de intrede op de arbeidsmarkt over het algemeen biel. Bij de sector BOL niveau $3 / 4$ gedrag en maatschappij is $5 \%$ van de schoolverla vier maanden of langer werkloos geweest en bij BBL niveau 3/4 gedrag en maatscl pij is dit percentage $6 \%$. Voor de andere sectoren van de BOL en de BBL (zowe niveau $1 / 2$ als niveau 3/4) geldt dat dit percentage lager is dan voor de sector gedra maatschappij.

\section{Werkzekerbeid}

Figuur 1.10 gaat in op de werkzekerheid van werkzame schoolverlaters (zie tabel van de Statistische Biflage). Weergegeven is het percentage werkzame schoolverl: met een flexibele aanstelling. Onder een flexibele aanstelling wordt verstaan een stclling als uitzendkracht, oproepkracht e.d. of een tijdelijke aanstelling.

Voor werkende schoolverlaters van het AVO is de werkzekerheid het minst groot name veel schoolverlaters van het HAVO (48\%) en het VWO (44\%) hebben een hele anstelling. Van de VBO-schoolverlaters heefi in totaal $24 \%$ een flexibele aar ling. Datarbij is het percentage VBO-schoolverlaters met een flexibele arbeidsro relatief hoog in het IVBO en de sectoren landhouw en economie. Bij de BOL. heeft van de schoolverlaters van niveau $1 / 2$ en $22 \%$ van de schoolverlaters van niveau $3 / \%$ Rexibele alanstelling. Hierbij valt op dat de sector economie van zowel BOL nivear als BOL niveatu $3 / 4$ relatief veel thexibele werknemers kent.

13ij B13L. nive:au $1 / 2$ heeft $15 \%$ van de schoolverlaters een flexibele aanstelling: bi niveilu, $3 / 4$ is dit 5\%. De werkzekerheid voor schoolverlaters van de BBL is groot, o BlBL-ers in het kader van de opleiding al betaald werk hebben verricht en na het ten van cle opleiding valk voor dezelfde werkgever zijn blijven werken. Dil bet clat veel BBL-ers anderhall jaar na het behalen van het diploma een vaste aanst hebben, watubij de lijclelijke leer-arbeidsovereenkomst is omgezet in een vast $d$ verband. Ook voor de BBL. geldt overigens dat in de sector economie het at 
Figuur 1.10

Percentage werkzame schoolverlaters met een flexibele aanstelling en percentage werkzame schoolverlaters met een deeltijdaanstelling per opleidingssector

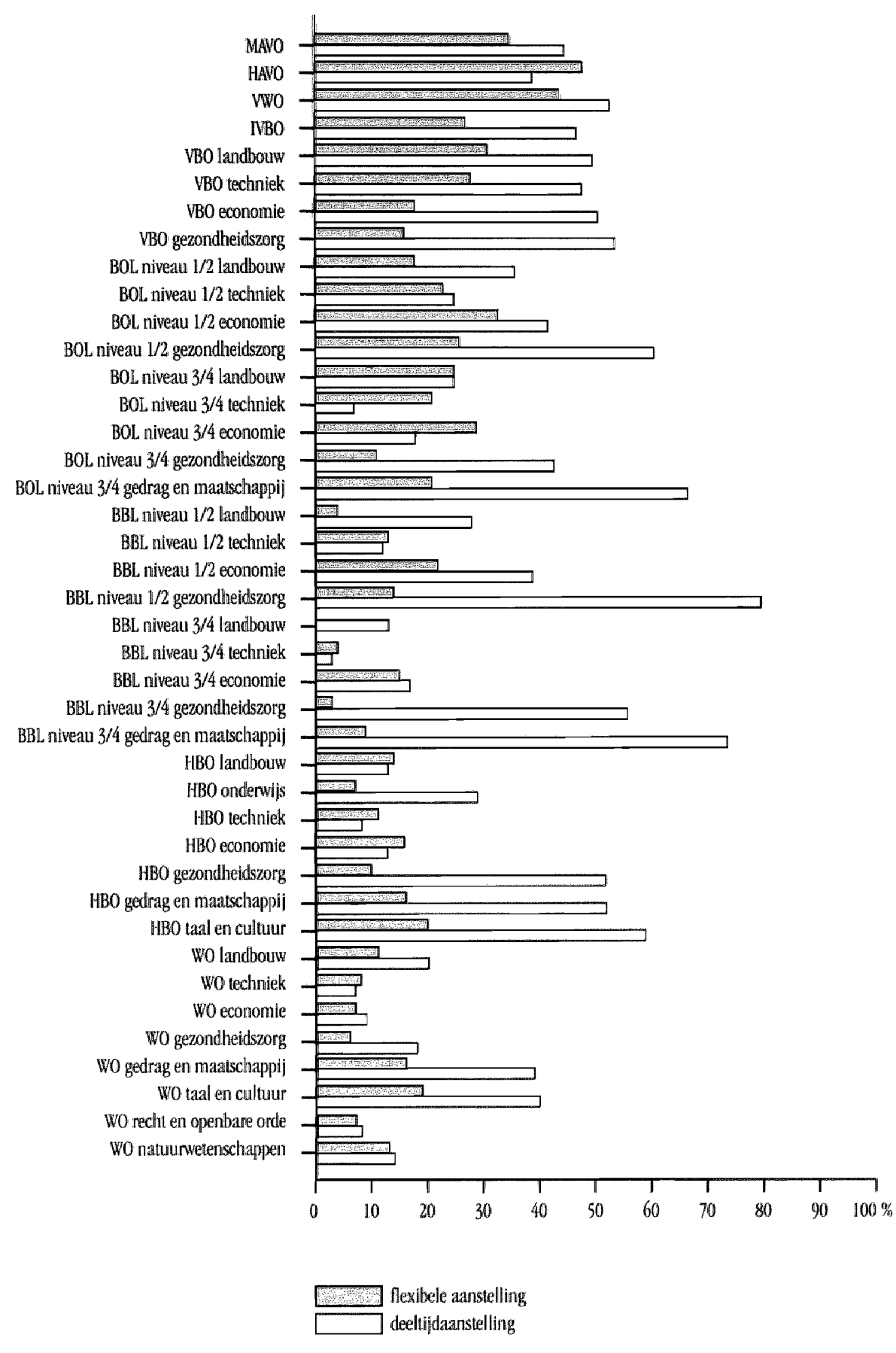


Voor het WO ligt dit percentage iets lager. In de sector taal en cultuur van het HBO het WO is het aandeel afgestudeerden met een flexibele aanstelling het hoogst. De st toren $\mathrm{HBO}$ onderwijs, WO techniek, WO economie, WO gezondheidszorg en WO re en openbare orde kennen relatief weinig flexibele werknemers.

In figuur 1.10 is ook het percentage werkzame schoolverlaters met een deelti aanstelling vermeld. Over het algemeen werken vrouwen vaker dan mannen in deelt Daarom mag worden verwacht dat in de sectoren waar vrouwen zijn overv tegenwoordigd (gezondheidszorg, gedrag en maatschappij) het aandeel schoolverlat met een deeltijdaanstelling hoger is dan in sectoren waarin mannen zijn oververteg woordigd (techniek). In totaal heeft $32 \%$ van de werkzame schoolverlaters een de tijdaanstelling. Het aandeel schoolverlaters dat in deeltijd werkt is met name hoog het AVO, het VBO en BOL niveau 1/2. Daarbij geldt voor het AVO dat veel schoolv laters van het VWO in deeltijd werken. Bij het VBO zijn er wat dit betreft weinig v schillen tussen sectoren. Bij $\mathrm{BOL}$ niveau $1 / 2$ zijn het vooral schoolverlaters van de sec gezondheidszorg die in deeltijd werkzaam zijn.

Voor zowel BBL niveau $1 / 2$ als BBL niveau $3 / 4$ geldt dat $29 \%$ van de schoolverlaters deeltijdaanstelling heeft. Ook hier is in de sector gezondheidszorg het aandeel scho verlaters met een deeltijdaanstelling hoog. Bij BBL niveau $1 / 2$ gezondheidszorg we $80 \%$ van de schoolverlaters in deeltijd; bij BBL niveau 3/4 gezondheidszorg is dit 5 Daarnatast werkt $74 \%$ van de schoolverlaters van de sector $\mathrm{BBL}$ niveau $3 / 4$ gedrag matschappij in deeltijd. In de sector techniek van BBL niveau $1 / 2$ en BBL niveau $3 /$ het aandleel schoolverlaters met een deeltijdaanstelling het laagst. In het $\mathrm{HBO}$ we $26 \%$ van de afgestudeerden in deeltijd. In de sectoren $\mathrm{HBO}$ gezondheidszorg, $\mathrm{H}$ gedrag en maatschappij en $\mathrm{HBO}$ taal en cultuur heeft meer dan de helft van de af studeerden een deeltijdaranstelling. Ook in het $\mathrm{HBO}$ werken weinig afgestudeerden de sector techniek in cleeltijd. Ten slotte heeft eenviffde van de WO-afgestudeerden deeltijdaanstelling. Voor het WO geldt dat met name veel afgestudeerden van de se ren gedrag en matschappij en taal en cultuur in deeltijd werken.

\section{Kwaliteil van bet werk:}

In de figuren 1.11 en 1.12 staat de kwaliteil van het werk van schoolverlaters centr Eerst word cle atansluiting tussen de gevolgde opleiding en de huidige baan besprok Van de aansluiting tussen de gevolgde opleiding en de huidige baan bestuderen twee aspecten: (1) de aanshuiting van de huidige baan met het bereikte opleiding veat en (2) de alansluiting van de huidige baan met de gevolgde opleidingsticht Hievoot zijn respondenten gevraagd aan te geven welk opleidingsniveau en wo opleidingsrichting voor de huiclige functie door de werkgever werd vereist. Figuur vermekli zowel het percentage werkzame schoolverlaters met een baan op minit het eigen opleidingsniveau als het percentage schoolvertaters met een baan in de e of verwante opleidingstichting (zie tabel A3.8 en tabel A3.9 van de Statistiscbe Bijlo

In lotal heett $71^{\circ}$ van de werkame schoolverlaters een baan gevonden op minir het eigen opleidingsniveau. Dit percentage is iets lager in vergelijking met het afg pen jar. Bij het AVO is het andeel schoolverlaters met een baan die past bij het $e$ 
Figuur 1.11

Percentage werkzame schoolverlaters met een baan op minimaal eigen niveau en percentage schoolverlaters met een baan in eigen/verwante richting per opleidingssector

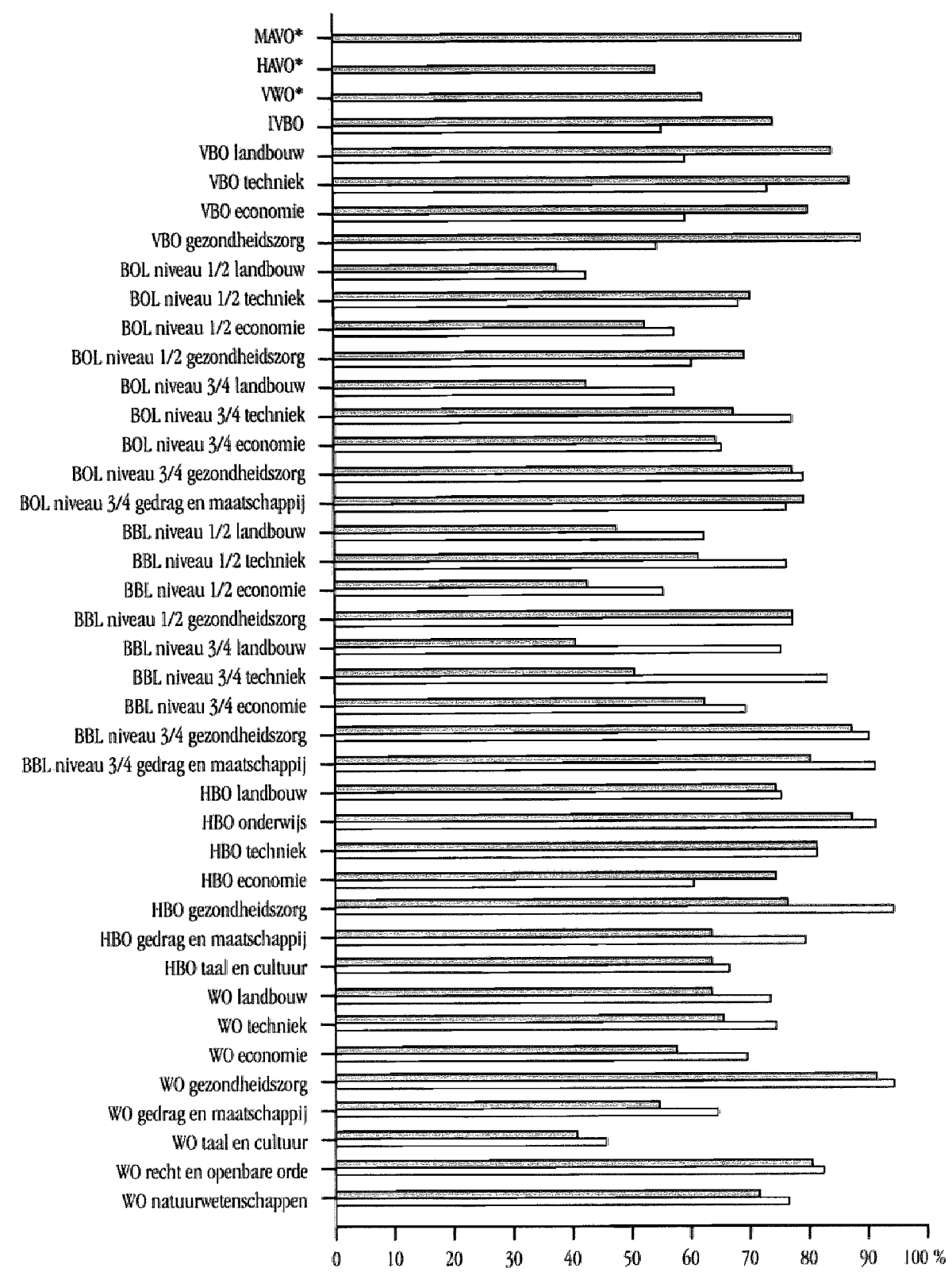

* eigen/verwante richting niet van toepassing 
woor rekening wan schoolverlaters van het HAVO en het VWO. Het VBO, BOL nive $1 / 2$ en BBL niveau $3 / 4$ laten daarentegen een aanzienlijke stijging zien van het aande schoolverlaters met een baan die aansluit bij het gevolgde opleidingsniveau. $\mathrm{Bij} B C$ niveau $3 / 4, \mathrm{BBL}$ niveau $1 / 2$, het $\mathrm{HBO}$ en het $\mathrm{WO}$ is dit aandeel vrijwel gelijk in verg lijking met vorig jaar.

Gemiddeld genomen vinden schoolverlaters van het VBO het vaakst een baan die aa sluit bij het gevolgde opleidingsniveau. In totaal heeft $86 \%$ van de VBO-schoolverlat een baan op minimaal het eigen opleidingsniveau. Bij BOL niveau $1 / 2$ is dit percen ge een stuk lager. Wat hier opvalt zijn de grote verschillen tussen de sectoren. Bij de se toren $\mathrm{BOL}$ niveau $1 / 2$ techniek en $\mathrm{BOL}$ niveau $1 / 2$ gezondheidszorg heeft ongeve $70 \%$ van de schoolverlaters een baan gevonden die aansluit bij het gevolgde opl dingsniveau, terwijl dit percentage veel lager is voor schoolverlaters van de sector BOL niveau $1 / 2$ landbouw en BOL niveau $1 / 2$ economie. Voor BOL niveau $3 / 4$ ge ook dat relatief weinig schoolverlaters van de sector techniek een baan op minimaal eigen opleidingsniveau hebben gevonden. Schoolverlaters van de sectoren BOL nive $3 / 4$ gezondheidszorg en $B O L$ niveau $3 / 4$ gedrag en maatschappij hebben duide vaker een baan gevonden die aansluit bij het gevolgde opleidingsniveau.

Bij de BBL heeft $58 \%$ van de schoolverlaters van niveau $1 / 2$ en $69 \%$ van de schoolv laters van niveau $3 / 4$ een baan gevonden die qua niveau aansluit bij de gevolgde op? ding. Verder komt hier een vergelijkbaar beeld naar voren als bij de BOL. Bij BBL nive $1 / 2$ vinden schoolverlaters van de sectoren techniek en gezondheidszorg het vaakst baan op het eigen niveau; bij BBL niveau $3 / 4$ geldt dit voor schoolverlaters van de $s$ toren gezondheidszorg en gedrag en maatschappij. Bij het $\mathrm{HBO}$ heeft $77 \%$ van de af studeerden een baan op het eigen niveau gevonden. Het zijn hier voo afgestudeerclen van de sector onderwijs die een baan hebben op minimaal het eig opleidingsniveau. Opvallend voor het WO is dat veel afgestudeerden van de sec gezondheidszorg een baan op WO-niveau vinden. Bij de andere WO-sectoren geldt dit percentage achterbliff in vergelijking met de sector gezondheidszorg. Bij de sec WO tatil en cultuur is het percentage afgestudeerden met een baan die aansluit bij gevolgcle opleidingsniveau het laagst.

Het percentage schoolverlatters met een baan in de eigen of verwante opleidingsricht is in vergelijking met 2001 met 5\%-punten toegenomen (van 69\% naar 74\%). Dit $p$ centage is bij alle onderwijssootten gestegen, waarbij het VBO (11\%), BOL niveau $(6 \%)$, BBL niveau $1 / 2(9 \%)$ en BBL niveau $3 / 4(10 \%)$ de sterkste stiging laten zi Schoolverlaters van BBL nivealu $3 / 4$ vinden gemiddeld genomen het valakst een baan de eigen of verwante richting. In totaal heeft $84 \%$ van de schoolverlaters van BBL niv $3 / 4$ een batan gevonden die qua richting aansluit bij de gevolgde opleiding. Verder ge voor veet onderwijssoorten dat schoolverlaters van de sectoren techniek en gezo heidszorg vatk een baan hebben gevonden die aansluit bij de gevolgde opleidir richting. Dil geldt ook voor de sectoren BBL niveau $3 / 4$ gedrag en matschappij en $\mathrm{H}$ onderwijs. Voor de sectoren $\mathrm{BOL}$ niveau $1 / 2$ landbouw, $\mathrm{HBO}$ economie, $\mathrm{HBO}$ taal cultuur en WO taal en cultuur geldt darentegen dat relatief weinig schoolverlaters baan heblen gevonden die qua richting aansluit bij de gevolgde opleiding. 
Figuur 1.12

Beloning op basis van bruto uurloon van werkzame schoolverlaters per opleidingssector

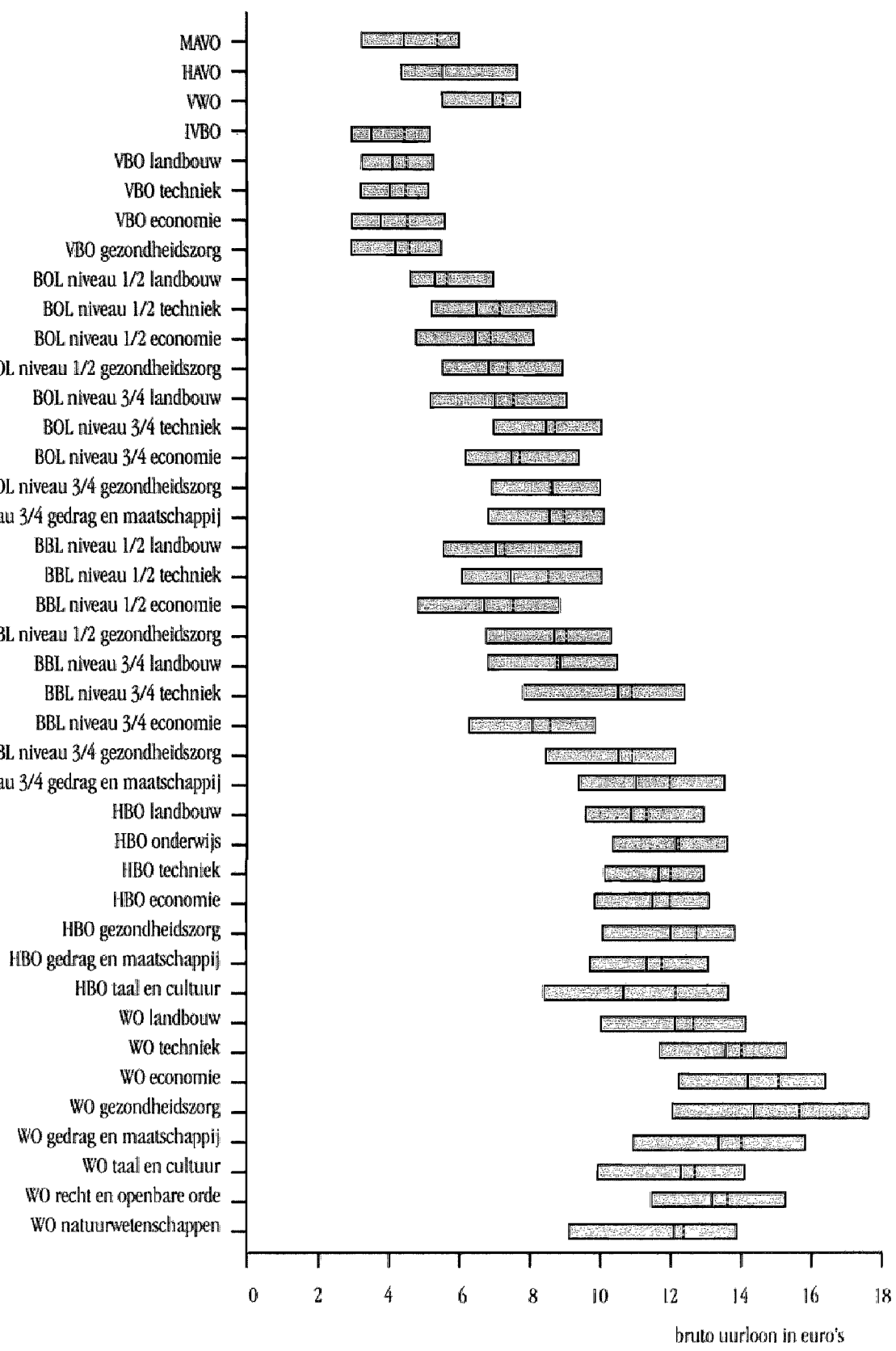

BBL niveau $1 / 2$ techniek

$1 / 2$ gezondheidszorg

BL. niveau $3 / 4$ landboum

BBL niveau $3 / 4$ techniek

BBL niveau $3 / 4$ economie

BBL niveau $3 / 4$ gezondheidszor:

BBL niveau $3 / 4$ gedrag en maalschappij HBO landbouw

$\mathrm{HBO}$ onderwijs HBBO techriek

.

wo landbouw

wo techniek:

wo economie

0 gezondheidszorg

gedrag en maatschappij

WO taal en cultuur

wo recht en openbare orde

WO natururvelenscliappen

bruto uurloon in euros 
In figuur 1.12 wordt ingegaan op de beloning van schoolverlaters. In deze figuur is bruto uurloon van werkzame schoolverlaters vermeld. In vergelijking met 2001 is alle het bruto uurloon van afgestudeerden van het $\mathrm{HBO}$ en het WO toegenomen. Bij 1 $\mathrm{HBO}$ zijn de aanvangssalarissen van afgestudeerden met $3 \%$ gestegen; bij het WO z de aanvangssalarissen met $4 \%$ gestegen. Voor de andere onderwijssoorten geldt dat aanvangssalarissen gelijk zijn gebleven of licht zijn gedaald.

Voor schoolverlaters van het VBO is het startsalaris gemiddeld 4,40 euro. Figuur 1 laat zien dat de verschillen tussen de sectoren van het VBO gering zijn. Bij de BOL de BBL (zowel op niveau $1 / 2$ als niveau $3 / 4$ ) bestaan tussen de sectoren wel versch len in het bruto uurloon van schoolverlaters. Vooral schoolverlaters van de sector te niek en de sector gezondheidszorg hebben een hoog bruto uurloon. Ook voor sectoren BOL niveau $3 / 4$ gedrag en maatschappij en BBL niveau $3 / 4$ gedrag en ma schappij geldt dat het startsalaris van schoolverlaters relatief hoog is. Het aanvangssa ris van schoolverlaters van de sectoren landbouw en economie is relatief laag bij BOL en de BBL. Bij het HBO liggen de aanvangssalarissen gemiddeld het hoogst in sectoren $\mathrm{HBO}$ gezondheidszorg en $\mathrm{HBO}$ onderwijs. Voor het WO geldt dat afges deerden van de sector WO gezondheidszorg het hoogste aanvangssalaris hebben. I aanvangssalaris van afgestudeerden van de sectoren WO landbouw, WO taal en cult en WO natuurwetenschappen is daarentegen relatief laag.

Om aan te geven in hoeverre binnen een opleidingssector de beloning van werkza schoolverlaters van ellkaar verschilt is in figuur 1.12 ook de spreiding van het bruto $u$ loon vermeld. Weergegeven is het $25 \%$-kwartiel, de mediaan en het $75 \%$-kwartiel. mediaan geeft het bruto uurloon waar $50 \%$ van de werkende schoolverlaters onder en $50 \%$ van de werkende schoolverlaters boven zit; het $25 \%$-kwartiel geeft het br uurloon waar $25 \%$ van de werkende schoolverlaters onder zit en $75 \%$ boven zit; $75 \%$-kwartiel geeft het bruto uurloon waar $75 \%$ onder zit en $25 \%$ boven zit. De Sp ding van het bruto uurloon is het grootst bij de BBL en het WO. Bij BBL niveau $1 / 2$ de sector landhouw een grote spreidling van het bruto urtoon zien. Bij BBL niveat geldt dit voor de sector techniek. Binnen het WO is de spreiding van het bruto uurk het grootst bij de sector gezondheidszorg. Dit kan te maken hebben met het feil dalt clecel van de afgestudeerden van deze sector nog in een specialisatietraject zit. Vercle opvallend atan figutr 1.12 dal bij de sector HBO taal en cultuur de spreiding van bruto unrloon relatief grom is.

\section{Oordecl oner de opleiding}

Voor schoolverlaters die de arbeidsmarkt betreclen, vormt de afgesloten opleiding hasis voor de beroepslooplaan. Daarbij is van belang dat de opleiding goed is at stend op het latere werk. Figuur 1.13 vermeld het percentage werkzame schoolve ters dall angeti dat in de huiclige baan de opgedane kennis en vaardigheden wor benut. I lit dexe figuur blijkt dat schoolverlaters van het AVO en het VBO minder $v$ arangeven dat in de huidige functie de opgedane kennis en vaardigheden worden be dan schoolverlaters van andere onderwijssoorten. Op zich is dit niet vreemd, ondat voorlgerel onderwijs toch vooral als voorbereiding op een vervolgopleiding kan v den beschouwd. verder blijkt dal schoolverlaters van de BBL gemiddeld genor 
Figuur 1.13

Percentage werkzame schoolverlaters dat aangeeft dat in de huidige baan de opgedane kennis en vaardigheden worden benut en percentage werkzame schoolverlaters dat aangeeft dat in de huidige baan de opgedane kennis en vaardigheden tekort schieten per opleidingssector

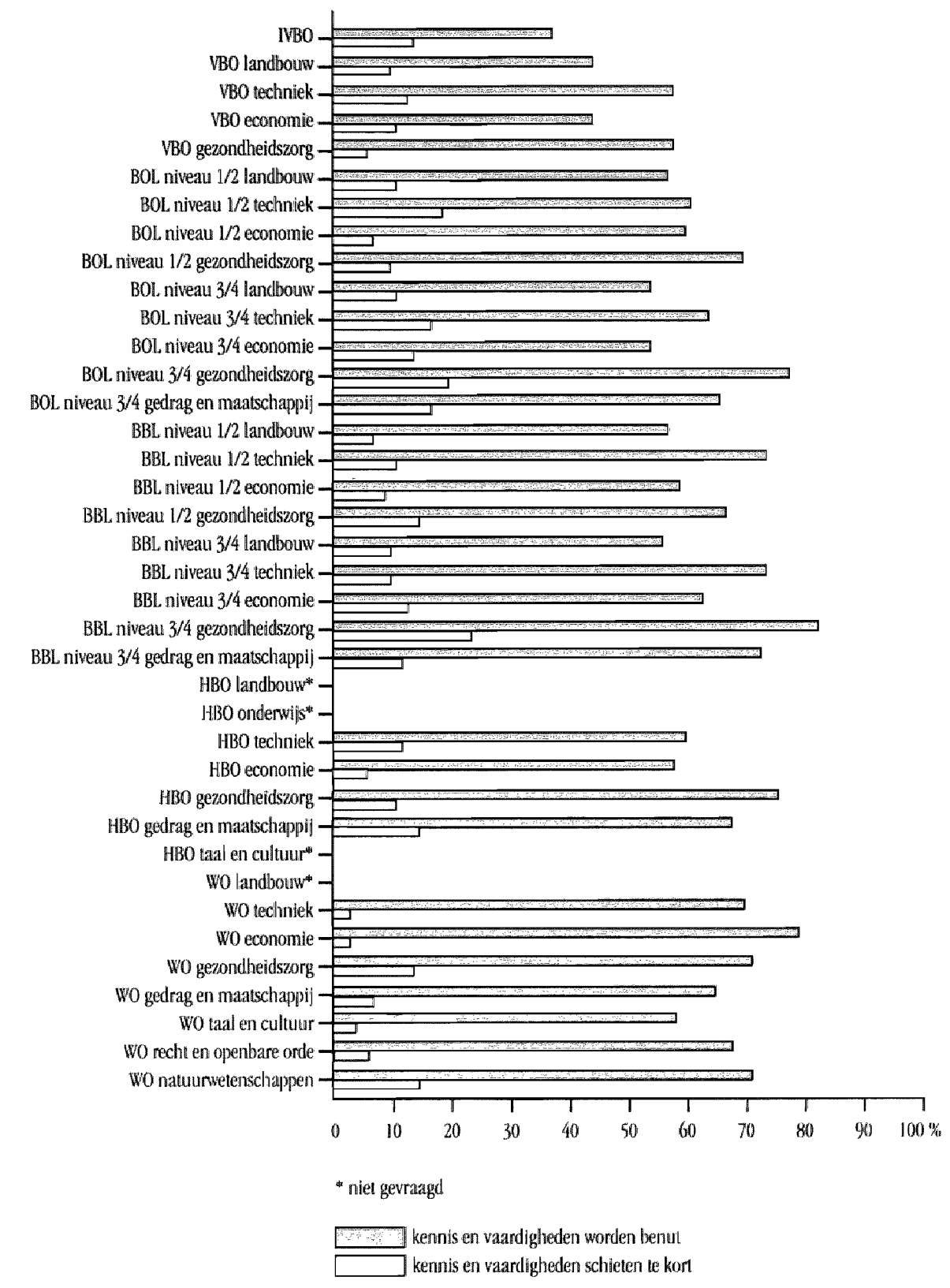


kennis en vaardigheden worden benut. Waarschijnlijk heeft dit te maken met het feit opleidingen van de BBL meer zijn afgestemd op het latere werk dan opleidingen de BOL. De verplichte praktijkcomponent bestaat bij de BBL uit minstens $60 \%$ van opleiding; bij de BOL uit minstens $20 \%$ en maximaal $60 \%$. Overigens bestaan er tus: de sectoren van de BOL en de BBL verschillen. Voor de BOL geldt dat schoolverlat van de sector gezondheidszorg het vaakst aangeven dat in de huidige functie de op dane kennis en valardigheden worden benut. Bij de BBL geldt dit naast de sec gezondheidszorg ook voor de sectoren techniek en gedrag en maatschappij. Voor HBO geldt dat relatief weinig afgestudeerden van de sector techniek aangeven dat in huidige functie de in de opleiding opgedane kennis en vaardigheden worden ber verder geldt ook hier dat dit aancleel hoog is voor de sector gezondheidszorg. In wO zijn het echter de afgestudeerden van de sector economie die het vaakst zeggen de opgedane kennis en vaardigheden worden benut in de huidige ba Afgestudeerden van de sector WO taal en cultuur 'scoren' daarentegen het laagst.

Tevens is in tabel 1.13 aangegeven in hoeverre schoolverlaters vinden dat de opge ne kennis en vaardigheden tekort schieten voor de huidige baan. Opvallend is dat $r$ tief veel schoolverlaters van de sector gezondheidszorg zeggen dat de opgedane ker en vaardigheden voor de huidige baan tekon schieten (bij BOL niveau 3/4, BBL niv $1 / 2$, BBL niveau $3 / 4$ en WO). Hier lijkt dus eerder sprake te zijn van over- dan ond benutting. Verder komt naar voren dat in het $\mathrm{HBO}$ afgestudeerden van de sector gec en maatschappij en in het WO afgestudeerden van de sector natuurwetenschap relatief vaak zeggen dat de in de opleiding opgedane kennis en vaardigheden tek schieten voor de huidige baan.

In figuur 1.14 is het percentage werkzame schoolverlaters weergegeven dat de aans ting tussen opleiding en werk voldoende tot goed vindt. In totaal zegt $85 \%$ van de w zame schoolverlaters dat de alansluiting tussen de gevolgde opleiding en de huic functie voldoende tor goed is. Schoolverlaters van de BBL geven dit het vaakst aan zowel BBLL, niveau $1 / 2$ als BBL, niveau $3 / 4$ zegt ongeveer $90 \%$ van de schoolverlaters de aansluiting tussen opleiding en werk voldoende tot goed is. Ook hier geld dat watrschijnlijk te maken heeft met de nadruk die opleidingen van de BBL leggen of beroepscomponent. Bij BOL niveau $1 / 2$ valt op dat relatief veel schoolverlaters var sector landbouw aangeven dat de ansluiting tussen opleiding en werk voldoende goed is. $13 \mathrm{ij}$ BOL niveau $3 / 4$ zijn schoolverlaters van de verschillende sectoren onge even levreden over deze alansluiting. Voor het HBO vinden afgestudeerden van de tor onderwijs het vaalkst en afgestudeerden van de sector taal en cultuur het minst dat de atansluiting tussen opleiding en werk voldoende tot goed is. Bij het WO zijn at sudecerden van de sector tatal en cultuur duidelijk minder vaak dan afgestudeerden anclere sectoren tevreden over de aansluiting tussen de gevolgde opleiding en het dige werk.

In figurur 1.15 is vermetd of schoolverlaters met betald werk, achteraf bezien, opni voor dezelfde opleiding zouden kiezen. Bijna $80 \%$ van de werkende schoolverla geeft an dezellde opleiding te kiezen. Daarbij geven werkende schoolverlaters BOL niveau $1 / 2$ het minst valak aan dat ze opnieuw dezelfde opleiding willen vol Dit percentage is vooral laag voor schoolverlaters van de sector BOL niveau 
Figuur 1.14

Percentage werkzame schoolverlaters dat de aansluiting tussen opleiding en werk als goed of voldoende beoordeelt per opleidingssector

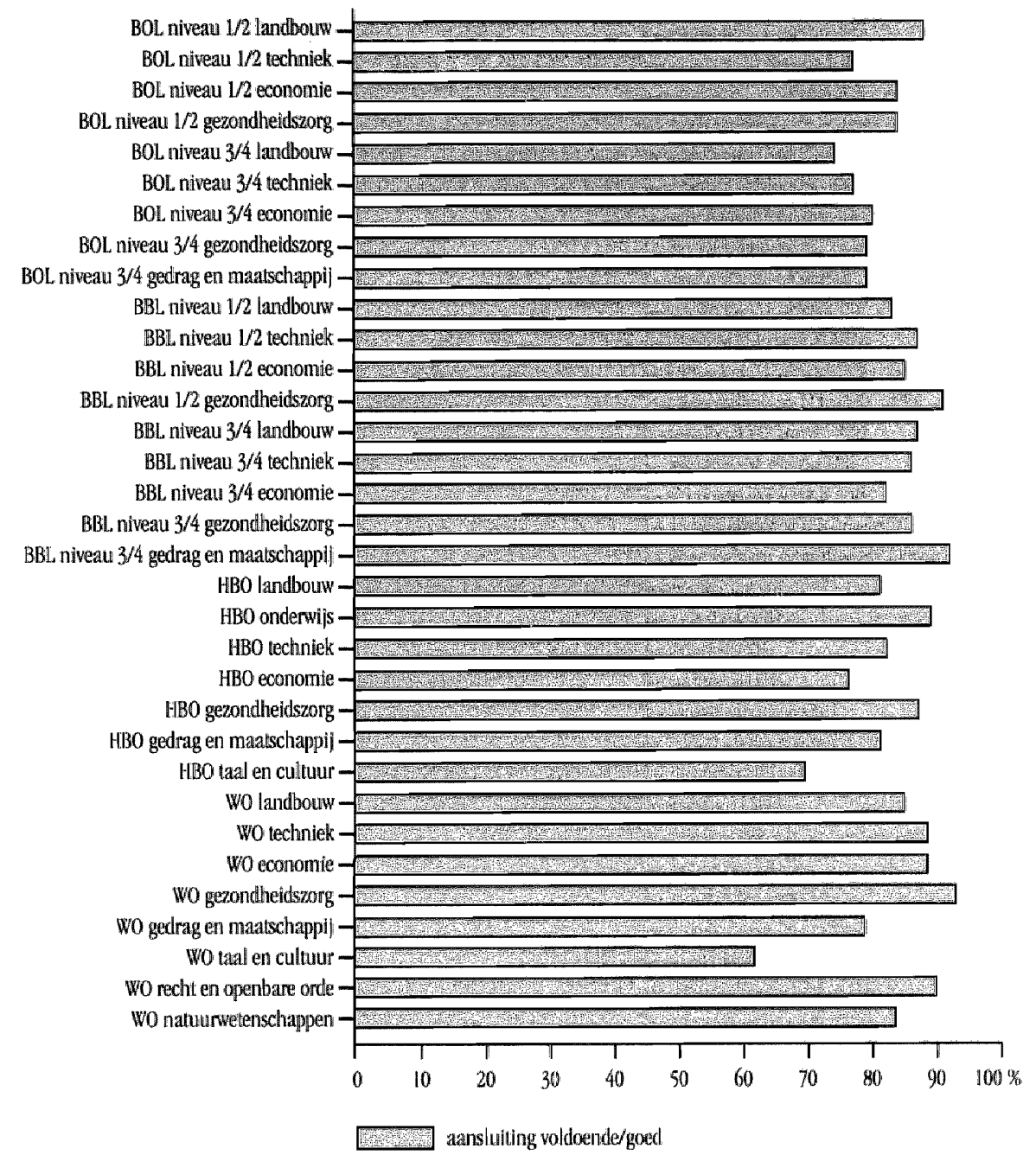

aan, achteraf bezien, dezelfde opleiding te kiezen. Wat dit betreft bestaan er verschillen tussen sectoren van BOL niveau 3/4. Bij de sector technick zegt $83 \%$ van de schos verlaters opnieuw dezelfde opleiding te willen volgen. Bij de sector landbouw gedd dil voor $68 \%$ van de schoolverlaters. Bij de BBBL geeff ook driekwarl van de schoolverlaters van niveau $1 / 2$ en $81 \%$ van de schoolverlaters van niveau $3 / 4$ atan dat $\%$ opneuw dezelfde opleiding zouden kiezen. Dit percentage is bij $13 B \mathrm{~L}$ niveau $1 / 2 \mathrm{icts}$ lager voor de sectoren landbouw en economie Bij $1313 \mathrm{~L}$ niveau $3 / 4$ is dit percentage veor de sec- 
Figuur 1.15

Percentage werkzame schoolverlaters dat achteraf bezien dezelfde opleiding zou volgen per opleidingssector

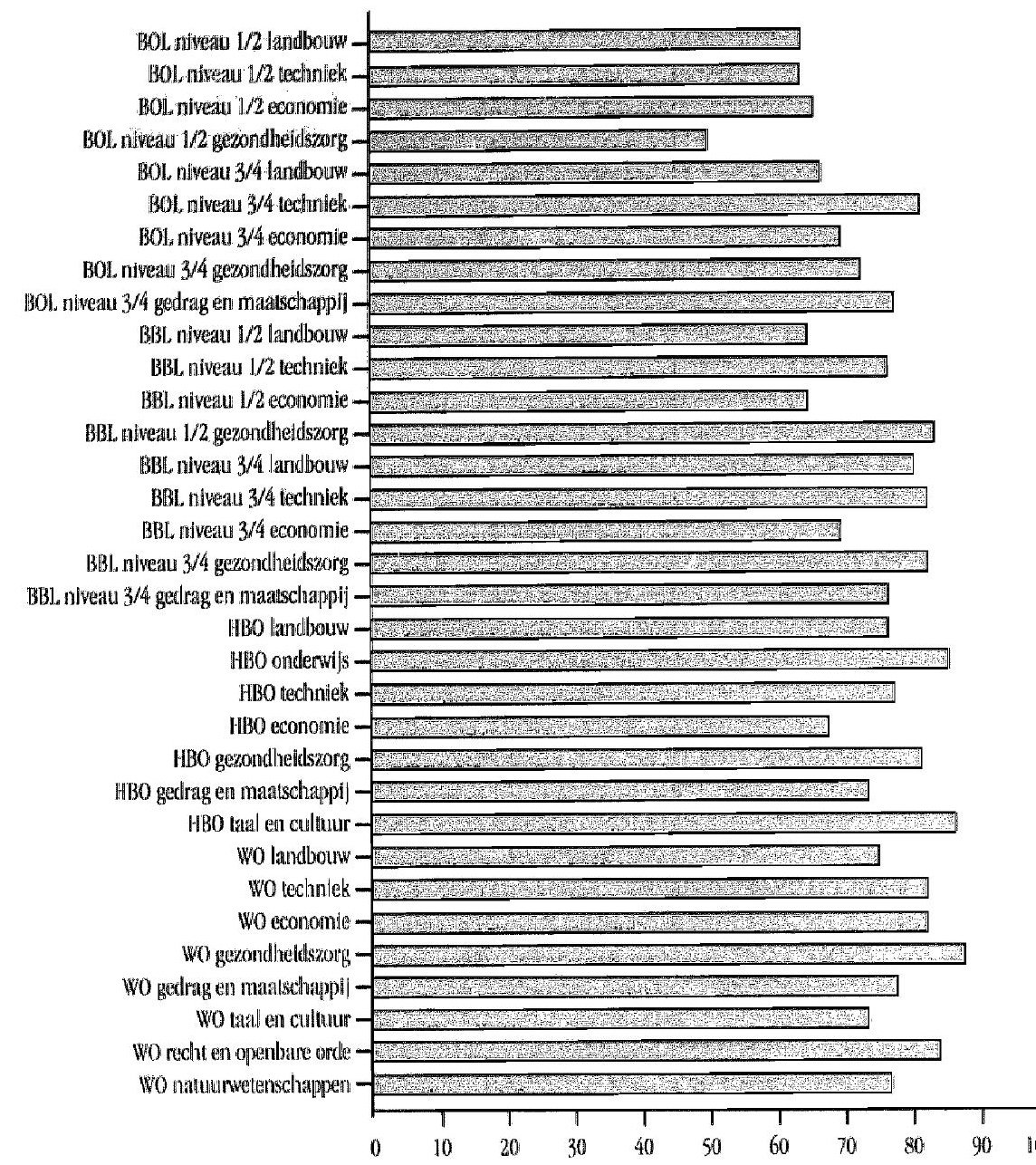

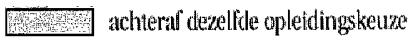

respectievelijk 77\% en $80 \%$ van de afgestudeerden met betaald werk, achteral bez derelfie opleiding zou kiezen. Bij het $\mathrm{HBO}$ valt op dat afgestudeerden van de se economie minder valk dan atgestudeerden van andere sectoren aangeven da dezelfule opleiding opnieuw willen volgen. In het wO zeggen afgestudeerden val sector gerondleidszorg het valikst dat ze dezelfde opleiding opnieuw zouden kiez 


\section{Arbeidsmarktpositie van opleidingen}

Tot slot van deze paragraaf wordt aangegeven voor welke opleidingssectoren de transitie van school naar werk voorspoedig verloopt en voor welke minder voorspoedig. Dit gebeurt aan de hand van de belangrijkste indicatoren over de arbeidsmarktpositie van schoolverlaters. Door middel van factoranalyse zijn deze indicatoren herleid tor twee dimensies: 'werkgelegenheid en werkzekerheid' en 'kwaliteil van het werk', De dimensie 'werkgelegenheid en werkzekerheid' kent hoge factorladingen op de indicatoren 'percentage werkzame beroepsbevolking', 'percentage schoolverlaters dat korter dan vier maanden werkloos is geweest' en 'percentage vaste aanstellingen'. De dimensie 'kwaliteit van het werk' kent hoge ladingen op de indicatoren 'percentage schoolverlaters met een baan op het eigen opleidingsniveau', 'percentage schoolverlaters met een baan in de eigen/verwante richting' en 'gemiddeld bruto uutloon'. Door samenvoeging van de verschillende indicatoren zijn schalen samengesteld voor de beicle dimensies. ${ }^{10}$ Aan de hand hiervan is bepaald hoe verschillende opleidingssectoren ten opzichte van elkaar scoren op de twee dimensies. "Tabel 1.1 geeft een kwalitatieve typering van de scores van de onderscheiden opleidingssectoren op beide dimensies. ${ }^{12}$

Tabel 1.1 laat zien dat voor schoolverlaters van het AVO de werkgelegenheid en werkzekerheid relatief slecht is. Daarnaast is de kwaliteit van het werk voor schoolverlaters van het MAVO en het VWO gemiddeld en voor schoolverlaters van het HAVO relatief slecht. Voor het VBO geldt dat de werkgelegenheid en werkzekerheid relatiel" slecht is voor schoolverlaters van het IVBO en schoolverlaters van de sector landbouw, terwij] dit voor schoolverlaters van de sectoren techniek, economie en gezondheidszorg gemiddeld tot relatief goed is. Verder is de kwaliteit van het werk relatief slecht voor schoolverlaters van het IVBO en de sector VBO economie. Voor schoolverlaters van BOL niveau $1 / 2$ en BOL niveau $3 / 4$ is de werkgelegenheid en werkzekerheid over het algemeen gemiddeld. Alleen bij de sector BOL $1 / 2$ economie is deze relatiet slecht en bij de sector BOL $3 / 4$ gezondheidszorg relatief goed. Daarnaast valt op dat de kwaliteit van het werk bij de alle sectoren van $130 \mathrm{~L}$ niveatu $1 / 2$ (mot uitzondering valn de sector techniek) relatief slecht of relatief zeer slecht is. Ook de kwaliteit van het werth voon schoolverlaters van de sector BOL niveau $3 / 4$ economice is rellticf slecht. Voor de owe rige sectoren van $B O L$ niveau $1 / 2$ en $B O L$ niveau, $3 / 4$ is de $k$ wall heit van het werk gemicldèld.

De werkgelegenheid en werkzekerheid zijn voor cle verschillende sectoren van $13 B$ B. niveau $1 / 2$ en BBL, nivealu $3 / 4$ gemiddeld tot relatief goed. Walt hetreft de kwallecil valn

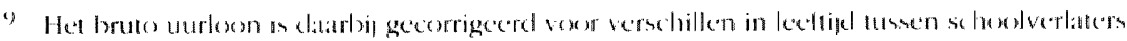

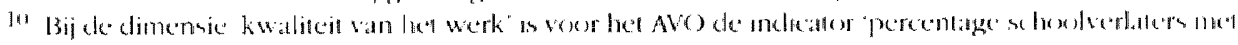
cen balan in de eigen verwante richeng' niet meegenemen

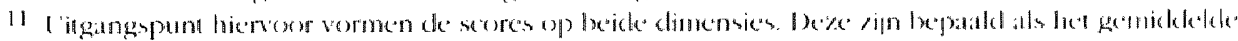

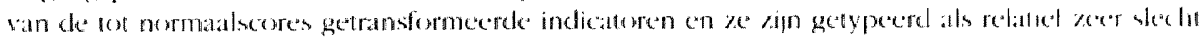

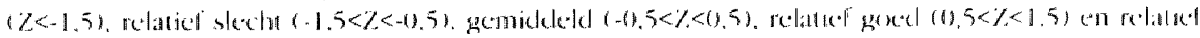
$\operatorname{xerg} \operatorname{goc}(2)>1,5)$

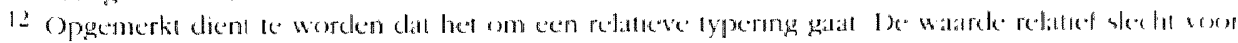

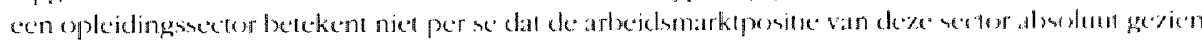

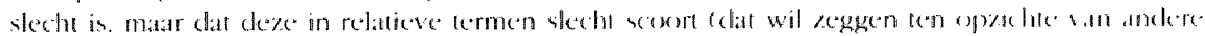


Tabel 1.1

Relatieve typering van 'werkgelegenheid en werkzekerheid' en 'kwaliteit van het werk' per opleidingssector

\section{Werkgelegenheid en werkzekertieid}

MAVO

HAVO

WWo

IVBO

VBO landbouw

VBO techniek

VBO economie

VBO gerondheidszorg

BOL niveau $1 / 2$ landbouw

BoL niveau $1 / 2$ techniek

$B O L$, niveau $1 / 2$ economie

BOL, niveau I/2 gezondheidszorg

BOL niveau 3/4 landbouw

BOL niveau 3/4 techniek

BOL. niveau $3 / 4$ economie

BOL niveau $3 / 4$ gezondheidszorg

BOL niveau 3/4 gedrag en maalschappij

BBL niveau $1 / 2$ landbouw

BBL. niveau $1 / 2$ techniek

BBL. niveau $1 / 2$ economie

BBL niveau $1 / 2$ gezondheidszorg

BBL nivesu $3 / 4$ landbouw

BBL, niveau $3 / 4$ techniek

BBL niveau $3 / 4$ economie

BBL nivesu $3 / 4$ gezondheidszorg

BBL niveau $3 / 4$ gedrag en maatschappii

$\mathrm{HBO}$ landbouw

HIBO onderwi|s

HIBO techniek

Illso economie

I.tBO gezondheidszorg

HIBO gedrag en matischappi|

I IBO tiat en cultuur

Wo landhouw

Wo technitek

Wo economite

Wo gezondhetdszorg

Wo gedrag en matschappij

WO tital en cultuur

Wo recht en open biare orde

WO natuurwetenschippen relatief slecht

rellatief zeer slecht

relatief slecht

relatief slecht

relatief slecht

gemiddeld

relatief goed

gemiddeld

gemiddeld

gemiddeld

relatief slecht

gemiddeld

gemiddeld

gemiddeld

gemiddeld

relatief goed

gemiddeld

relatief goed

relatief goed

gemiddeld

gemiddeld

relatief goed

relatief goed

gemiddeld

relatief goed

gemiddeld

gemiddeld

relatiel goed

gemiddeld

gemiddeld

relatief goed

gemiddeld

relatief slecht

relatiel slecht

gemiddeld

gemiddeld

relatief goed

relatief slecht

relatief stecht

gemiddeld

gemiddeld
Kwaliteit van het w

gemidd

relatief sle

gemidd

relatief sle

gernidc

gemidc

relatief sle

gemidc

relatief zeer sle

gernido

relatief sle

relatief sle

relatief sle

gemidc

rellatief sle

gemidc

gemidc

rellatief sle

gemido

relatief zeer sle

gemide

relatief sle

gemido

relatief sle

relatief $\mathrm{g}$

relatiel $\mathrm{g}$

gemido

relatief $\mathrm{g}$

relatief $g$

gemido

relatief :

gemido

gemid

gemid

relatief

gemid

relatief zeer

gemid

relatief s $s$

relatief \&

relatief :

het werk bestaln echter grote verschillen tussen de sectoren van de BBL. Voor niveau $1 / 2$ geldt dat de kwaliteit van het werk relatief slecht is voor schoolverlaters de sector landbouw, relatief zeer slecht is voor schoolverlaters van de sector econo en gemiddeld is voor schoolverlaters van de sectoren techniek en gezondheidszorg BBL, niveatu 3 is $k$ kwaliteit van het werk relatiel slecht voor schoolverlaters var 
gezondheidszorg en gedrag en maatschappij en gemiddeld voor schoolverlaters van de sector techniek. Voor afgestudeerden van het HBO geldt dat de werkgelegenheid en werkzekerheid over het algemeen gemiddeld tot relatief goed zijn. Alleen voor afgestudeerden van de sector taal en culturur zijn de werkgelegenheid en werkzekerheid relatief slecht. Daarnaast valt op dat ook de kwaliteit van het werk gemiddeld tot relatief goed is voor afgestudeerden van de verschillende sectoren van het $\mathrm{HBO}$. Overigens geldt voor afgestudeerden van $\mathrm{HBO}$ onderwijs en $\mathrm{HBO}$ gezondheidszorg dat zowel de werkgelegenheid en werkzekerheid als de kwaliteit van her werk relatief goed is. 'Tot slot blijkt dat een aantal sectoren van het WO relatief slecht 'scoren' wat betreft de werkgelegenheid en werkzekerheid. Dit zijn de sectoren WO landbouw, WO gedrag en maatschappij en wo taal en cultuur. Daarnaast is ook de kwalliteit van het werk relatief slecht voor afgestudeerden van de sector WO taal en cultuur. Voor afgestudeerden van de sector WO gezondheidszorg geldt dat de werkgelegenheid en werkzekerheid relatief goed is en de kwaliteit van het werk is relatief zeer goed. Daarnaast is de kwaliteit van het werk relatief goed voor afgestudeerden van de sectoren wO techniek, WO recht en openbare orde en WO natuurwetenschappen. 


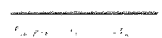

,

$\therefore \ldots$ 


\section{Schoolverlaters van het VBO en MAVO: de instroom in het secundair beroepsonderwijs vergeleken}

In het voortgezet onderwijs heeft de afgelopen jaren een vernieuwingsproces platsgevonden. Bij het HAVO en het VWO zijn examenprofielen en het studiehuis ingevoerd. Voor het MAVO en het VBO geldt dat ze zijn samengevoegd tot het VMBO (voorbereidend middelbaar beroepsonderwijs). Het cloel van deze veranderingen is de alansluiting met de vervolgopleiding te verbeteren. In bet schooljaar 1999/2000 is de eerste lichting scholieren in het VMBO gestart. Binnen het VMBO is de 'oude' MAVO de theoretische leerweg. Daarnaast kent het VMBO de kaderberoepsgerichte leerweg, de basisberoepsgerichte leerweg en de gemengde leerweg. De vrag is echter in hoeverre schoolverlaters van het MAVO en het VBO van elkaar verschillen wat betreft de verdere onderwijsloopbaan?

In dit hooldstuk wordt de instroom in het secundair beroepsonderwijs van schoolverlaters van het VBO en het MAVO vergeleken. Centraal staat de vrag in hoeverre de aansluiting tussen de gevolgde opleiding en de vervolgopleiding verschill voor schoolverlaters van het MAVO en het VBO. Eerst word bekeken welk deel van de schoolverlaters van het VBO en het MAVO verder gaat leren. Daarna word voor schoolverlaters die verder gaan leren in het secundair beroepsonderwijs anngegeven in welke leerweg en op welk niveau ze de onderwijsloopbaan vervolgen. Vervolgens wordt bestudeerd in hoeverre de aansluiting tussen de gevolgde opleiding en de vervolgopleiding in het secundair beroepsonderwijs goed verloopt. Een belangrijke indicator hiervoor is de voortijdige uitval van schoolverlaters in het eerste leerjatr van de vervolgopleiding. Verder wordt bekeken of de kennis en vaardigheden die schoolverlaters veel gebruiken in de vervolgopleiding voldoende aan bod zijn gekomen in de MAVO- of VBO-opleiding. Tor slot wordt onderzocht in hoeverre de eximenvalkken volgens MAVO- en VBO-schoolverlaters a ansluten bij de vervolgopleiding en loxe

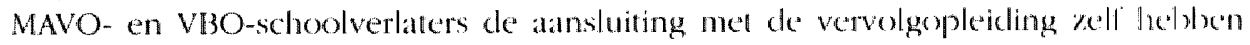
ervaren.

De gegevens die voor dit hoofdstuk zijn gebruikt, heblen betrekking op seluowvertaters van het MAVO en het VlBO die in het schooljatr $1909 / 2000$ het diploma hetblen behaald. Hel gat hier dus on schoolvententers van bet 'oude' MAVO en VBSO. Het gatal om in totaal 2.759 schoolverlaters, 1.513 MAVO-schoolverlaters en 1.246 VB30-school. verlaters. In de tabellen van dit hoofdstuk worden cijters gepresenteerd vor het MAVO) en het VBO. Daarnaast worden in de tabellen de ciffers vermeld voor de alfonderlijke sectoren van het VBO (landlsouw, techniek, economie en getondheidszorg), I) it is gedaan om te kijken in hoeverre lussen de sectoren van het VBOO verschillen bestatan.

\subsection{Achtergrondkenmerken en behaalde examenniveau}

In tabel 2.1 is een aantal achtergrondkenmerken van schoolvertaters van hed MAV() en

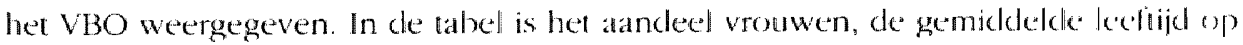
het moment valn ondervagen en het a andeel allochtonen vermeld. Uit dere $|a| x \cdot|x| i j k t$ 
is. Ongeveer de helft van de schoolverlaters van het MAVO en VBO is vrouw. Tuss sectoren van het VBO bestaan echter aanzienlijke verschillen. De sector VBO gez heidszorg bestaat bijna geheel uit vrouwen en in de sector VBO techniek zijn vrol veruit in de minderheid. Daarnaast komt naar voren dat schoolverlaters van het VB het MAVO vrijwel even oud zijn. Wat betreft de leeftijd van schoolverlaters is er $\mathrm{w}$ verschil tussen de sectoren van het VBO. Verder is opvallend dat het aandeel alloch schoolverlaters in de sector VBO economie zeer hoog is (32\%). In de andere sec van het $\mathrm{VBO}$ is het aandeel allochtonen gemiddeld lager dan bij het MAVO.

Tabel 2.1

Achtergrondkenmerken schoolverlaters MAVO en VBO

$\begin{array}{lccc} & \begin{array}{c}\text { Vrouw } \\ \%\end{array} & \begin{array}{c}\text { Leeftijd } \\ \text { gem. }\end{array} & \begin{array}{c}\text { Allochto } \\ \%\end{array} \\ \text { MAVO } & 52 & 17,3 & 11 \\ \text { VBO } & 50 & 17,4 & 14 \\ \text { VBO Landbouw } & 60 & 17,4 & 5 \\ \text { VBO lechniek } & 5 & 17,4 & 9 \\ \text { VBO Economie } & 62 & 17,5 & 32 \\ \text { VBO Gezondheidszorg } & 99 & 17,2 & 8\end{array}$

Tabel 2.2

Behaalde examenniveau van MAVO- en VBO-schoolverlaters

\begin{tabular}{|c|c|c|}
\hline & $\begin{array}{c}\text { A- of B-niveau } \\
\%\end{array}$ & C- of D-niveau \\
\hline MANo & $x$ & 100 \\
\hline VBO & 46 & 54 \\
\hline VBO Landhoum & 45 & 55 \\
\hline VBBO Tednriek & 60 & 40 \\
\hline VBOO kiconomic & 28 & 72 \\
\hline VBro Ciezondheidszorg & 46 & 54 \\
\hline
\end{tabular}

Leerlingen van het VBO kunnen examen doen op vier verschillende niveaus. oplo van A-niveau (hel latagste niveau) tot D-niveau (het hoogste niveau). Leerlingen va MAVO kunnen slechts examen doen op twee niveaus: C-niveau en D-niveau (zie 2.2). Het niveru van de behaalde opleiding is athankelijk van het niveau van de va die scholverlaters heblen behaald. Voor een diploma op D-niveau moet een lece Van het MAVO bijvoorbecld drie vakken op D-niveau stocesvol hebben afgerono tabel 2.2 kom nata voren dat meer dan de helft van de VBO-schoolverlaters een c ma op C-of D-niveau lheefi behald. Mel name veel schoolverlaters van de sector ecomomie hebben een diploma op dit nivealu (72\%). Voor schoolverlaters van des VBO techniek gelde datrentegen dat $60 \%$ een diploma van A- of B-niveau 


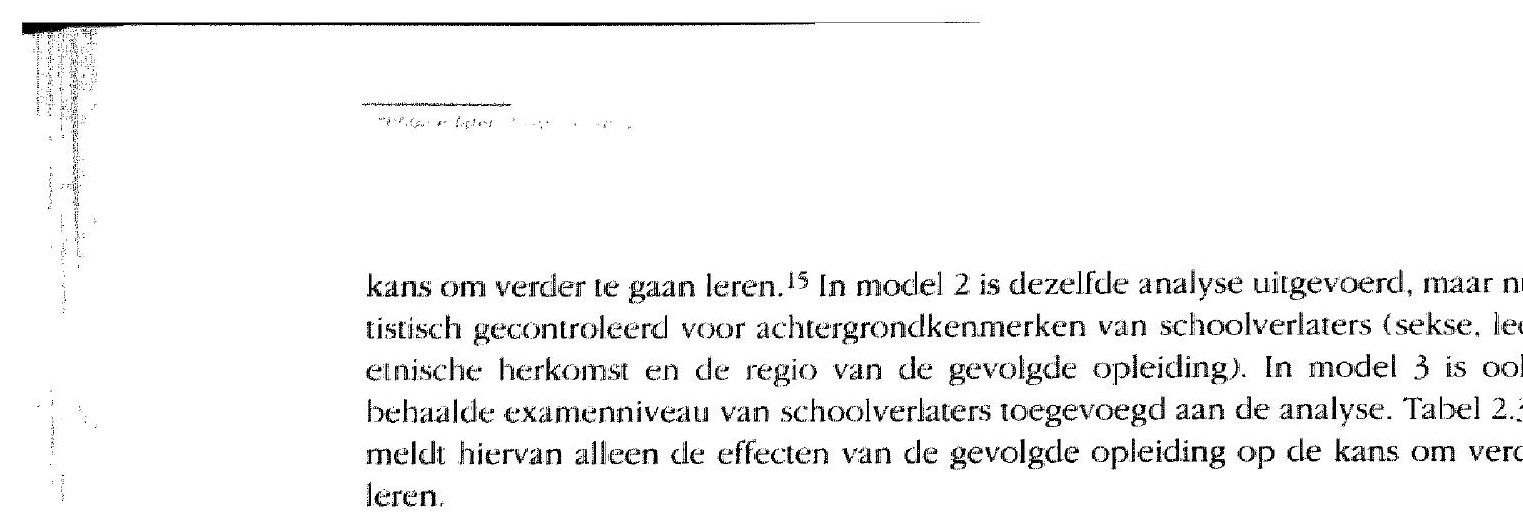

Model 1 van tabel 2.3 laat bij het VBO een significant negarief effect zien op de verder te gaan leren. Dit betekent dat de eerder gevonden verschillen tussen het en het MAVO in de kans verder te gaan leren significant zijn. Dit mag ook wo gezegd voor de verschillende sectoren van het VBO. Voor al de vier sectoren va VBO geldt dat ze significant afwijken van het MAVO wat betreft de kans verder te leren. Wanneer wordt gecontroleerd voor achtergrondkenmerken van schoolver in model 2 blijkt dat zowel de richting als de sterkte van de effecten vrijwel niet zijt anderd in vergelijking met model 1. Dit betekent dat de verschillen in samenstellin MAVO- en VBO-schoolverlaters geen verklaring geven voor het feit dat MAVO-sc verlaters vaker verder gaan leren dan VBO-schoolverlaters. In model 3 is het beh examennivea toegevoegd aan cle analyse. Dit model laat - in tegenstelling tot de gaande modellen - geen significante effecten meer zien bij het VBO. Dit geldr $z$ voor het totale VBO als de vier sectoren afzonderlijk. De verschillen in de kans on der te gaan leren tussen MAVO- en VBO-schoolverlaters kunnen datam worder geschreven aan de verschillen in het behaalde examenniveau. Schoolverlater's d een hoger niveau examen hebben gedaan kiezen vaker voor een vervolgopleidin schoolverlaters die op een lager niveau examen heblen gedaan. Eerder is in para 2.1 al aangegeven dat leerlingen van het MAVO gemiddeld genomen op een I niveau examen hebben gedaan. MAVO-schoolverlaters kunnen alleen examen cloe de hoogste niveaus (C-niveau of D-niveau), terwijl VBO-leerlingen ook kunnen $k$ voor een examen van lager niveau (A-niveau of B-niveau). Dat vooral de laagst a leicle schoolverlaters besluiten niet verder te gaan leren in een vervolgopleidling zorgwokkend worden genoemd. De latags opgeleiden zijn de meesi kwetsiba als het gatal on de kans op werk en de kwaliteil van het gevonden werk, vooral a situatio op de" arbeidsmarkt minder gunstig wordt. Overigens mag niet worden

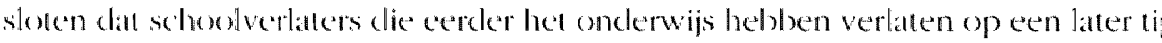
alsnog besluiten verder te gatan leren en een startkwalificatie behalen.

\section{Het wiverat ean de enolgopleiding}

Tialxel 2.4 laal zien op welk niveau verder lerende schoolverlaters van her MAVO e $V 130$ instromen in hee secundair bercepsonclerwijs. [lit cleze tabel blijkt dlat het grote deel van cle MAVO-schoolverlaters kiest voor een vervolgopleicling op niveat Slechas son van de MAVO-schoolverlatters gatilt een opleiding op niveau $1 / 2$ doen. Vl3O-schoolverlaters geld dall een kwan kiest voor een opleiding op niveau 1/2. C schoolverlaters wan de sector VBO techniek kom teen vervolgopleiding op nivea

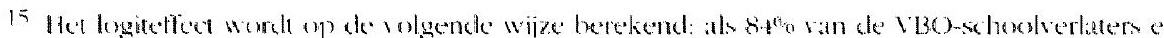


gezondheidszorg doorstromen naar de BOL. Bij de sector VBO techniek geldt dit 'slechts' $57 \%$ van de schoolverlaters.

Ook hier is een multivariate analyse uitgevoerd. Uit model 1 van tabel 2.5 blijkt a eerst dat de gevonden verschillen tussen MAVO- en VBO-schoolverlaters in de k voor de leerweg significant zijn. Ook als in model 2 achtergrondkenmerken van sch verlaters worden toegevoegd aan de analyse blijven deze verschillen statistisch sig cant. De sterkte van de effecten van het VBO zijn nauwelijks gewijzigd ten opzichte model 1 . Wederom neemt de sterkte van de effecten van het VBO af wanneer in $m$ 3 wordt gecorrigeerd voor het behaalde examenniveau van schoolverlaters. De effe van het VBO zijn in model 3 niet meer significant. Hieruit blijkt dat ook de keuze de leerweg vooral kunnen worden toegeschreven aan het behaalde examenniveau schoolverlaters. Schoolverlaters die het examen op een hoog niveau hebben beh: kiezen vaker voor de $\mathrm{BOL}$ in plaats van de $\mathrm{BBL}$ dan schoolverlaters die op een niveau het examen hebben behaald. Overigens blijkt dat sekse, etnische herkom leeftijd ook een rol spelen bij de keuze voor de leerweg. Mannelijke, allochtone en gere MAVO en VBO-schoolverlaters kiezen significant vaker dan vrouwelijke, aut one en oudere MAVO en VBO-schoolverlaters voor de BOL.

Tabel 2.5

De kans op doorstroom naar een vervolgopleiding in de BOL

\begin{tabular}{|c|c|c|c|c|}
\hline & $\underset{\%}{B O L}$ & Model 11 & Model $2^{2}$ & Model 3 \\
\hline MAVO & 89 & ref.cat. & ref.cat. & ref.cat. \\
\hline VBO & 72 & $-1,092^{*}$ & $-1,112^{*}$ & 0,048 \\
\hline VBO Landbouw & 73 & $-1,138^{\circ}$ & $-1,077^{*}$ & 0,176 \\
\hline VBO Techniek & 57 & $-1,706^{*}$ & $-1,892^{*}$ & $-0,484$ \\
\hline VBO Esconomite & 80 & $0,700^{* 4}$ & $-0,707^{*}$ & 0,379 \\
\hline VBO Gezondheitszorg & 80 & $0,680^{*}$ & $-0,598^{*}$ & 0,569 \\
\hline
\end{tabular}

\subsection{Aansluiting met het secundair beroepsonderwijs}

Voortijdige witnal in bet secundair beroepsonderwis

De overgang van MAVO en VBO naar het secundair beroepsonderwijs kan een ri moment vormen in de opleiding van jongeren. Om de kans op voortijdige uitval verder lerende schoolverlaters zo klein mogelijk te houden is het van belang da MAVO- en VBO-opleiding goed aansluiten op een opleiding in het secundair berc onderwijs. Te meer ondat deze schoolverlaters nog geen startkwalificatie het 
startkwalificatie (OCenW, 2002). In deze paragraaf wordt ingegaan op de aansluiting tussen de MAVO- en VBO-opleiding en de vervolgopleiding in het secundair beroepsonderwijs.

De voortijdige uitval van scholieren in de vervolgopleiding geeft een indicatie voor de aansluiting tussen de gevolgde opleiding en de vervolgopleiding. Wanneer de omvang van de voortijdige uitval van scholieren groot is kan dit duiden op een gebrekkige aansluiting tussen de gevolgde opleiding en de vervolgopleiding. Tabel 2.6 vermeld het percentage MAVO- en VBO-schoolverlaters dat de vervolgopleiding in het secundair beroepsonderwijs in het eerste leerjaar voortijdig heeft verlaten zonder dat het diploma is behaald. Deze tabel laat zien dat $13 \%$ van de MAVO-schoolverlaters en $10 \%$ van de VBO-schoolverlaters de vervolgopleiding in het secundair beroepsonderwijs voortijdig verlaat in het eerste leerjaar.

Tabel 2.6

De kans op uitval in de vervolgopleiding

\section{Voortijdig verlaten vervolgopleiding $\%$}

MAVO

VBO

VBO Landbouw

VBO Techniek

VBO Economie

VBO Gezondheidszorg
13

10

12

6

10

12
Model 11

Model $2^{2}$

ref.cat.

$-0,304$

$-0,048$

$-1,140^{*}$

$-0,257$

0,084 ref.cat.

$-0,499$

$-0,214$

$-1,571^{*}$

$-0,254$

$-0,135$
Model $3^{3}$

ref.cat.

$-0,538$

$-0,288$

$-1,693^{*}$

$-0,333$

0,051

$1=$ logiteffecten

$2=$ logiteffecten statistisch gecontroleerd voor sekse, leeftijd, etnische herkomst en regio gevolgde opleiding en behalalde examenniveau

${ }^{3}=$ logiteffecten statistisch gecontroleerd woor sekse, leefijid, etnische herkomst, regio gevolgde opledding, hehatalde examenniveau, type leerweg en niveau van de leerweg

$*=$ significant op $5 \%$-niveau

De kans op uitval is ook multivariaat geanalyseerd. Hiervoor zijn drie modellen geschall. De eerste twee modellen zijn vergelijkbar met eerder in dit hoofdstuk gepresenteercte modellen, waarin statistisch word gecontroleerd voor achtergrondkenmerken en het behaalde examenniveau van schoolverlaters. In model 3 word gecorrigeerd voor het type leerweg (BOL of $\mathrm{BBL}$ ) en het niveau van de leerweg (niveau $1 / 2$ of niveau $3 / 4$ ) van de vervolgopleiding. Uit model 1 blijkt dat het verschil tussen MAVO- en V13O-schoolverlaters in de kans om de vervolgopleiding voortijdig te verlaten niet statistisch significant is. Wel blijkt dat schoolverlaters van de sector VBO techniek significant minder vaak de opleiding voortijdig verlaten. Dit verschil blift significant als wordt gecontroleerd voor achtergrondkenmerken en het behalde examenniveau in modet 2. De andere sectoren van het VBO laten in moclel 2 geen significante effecten zien. Hetzelfde geldt voor model 3, waar is gecorrigeerd voor het type leerweg en het niveat van de: leerweg waatin schoolverlaters verder gaan leren. Wederom wijkt alleen cle sector VI3O techniek significant af van her MAVO, waarbij de sterkte van het effect uiteindelijk is toe- 
Overigens betekent dit niet dat andere kenmerken van schoolverlaters geen rol sp bif de voortijdig uitval van schoolverlaters. Voor MAVO- en VBO-schoolverlaters dat oudere schoolverlaters de vervolgopleiding vaker dan jongere schoolverlaters tijdig verlaten, en schoolverlaters die in het noorden van het land de opleiding het gevolgd verlaten vaker de vervolgopleiding voortijdig dan schoolverlaters die in westen van het land de opleiding hebben gevolgd. Daarnaast is het niveau van de volgopleiding van invloed op de kans de opleiding voortijdig te verlaten. Naar v komt dat schoolverlaters die kiezen voor een vervolgopleicling op niveau $1 / 2$ signif vaker uitvallen dan schoolverlaters die kiezen voor een vervolgopleiding op niveau

Tabel 2.7

Redenen om de vervolgopleiding voortijdig te verlaten*

\begin{tabular}{|c|c|c|c|c|c|}
\hline & $\begin{array}{c}\text { Vervolg- } \\
\text { opleiding } \\
\text { oninteressant }\end{array}$ & $\begin{array}{l}\text { Llever } \\
\text { gaan } \\
\text { werken }\end{array}$ & $\begin{array}{l}\text { Vervolg- } \\
\text { opleiding } \\
\text { te moeillijk }\end{array}$ & $\begin{array}{l}\text { Te weinig } \\
\text { motivatie }\end{array}$ & $\begin{array}{l}\text { Liever een } \\
\text { andere } \\
\text { opleiding } \\
\text { volgen }\end{array}$ \\
\hline & $\%$ & $\%$ & $\%$ & $\%$ & $\%$ \\
\hline MANO & 54 & 20 & 17 & 54 & 46 \\
\hline W130 & 17 & 1 & 12 & 15 & 48 \\
\hline \multicolumn{6}{|l|}{ VBO Landlbouw } \\
\hline VBO Techniek & 0 & 0 & 25 & 0 & 44 \\
\hline VBO Economie & 31 & 1 & 0 & 44 & 38 \\
\hline VBO Gezondheidszorg & 15 & 3 & 11 & 0 & 52 \\
\hline
\end{tabular}

Talxel 2.7 vermeld de redenen voor schoolverlaters om de vervolgopleiding in secundatir beroepsonderwijs in het eerste leerjatr voottijdig te verlaten. De belang ste redenen voor schoolverlaters vin het MAVO om de vervolgopleiding in het se dair beroupsonderwijs voortijelig te beäindigen zijn dall de vervolgoplei oninteressant word gevonden of omdat de motivatie ontloreekt om de opleiding maken. Datarmat zeggen veel MAVO-schoolverlaters dat ze cle vervolgopleiding tijdig verlaten ondat $z$ licver een andere opleiding volgen. Voor schootverlaters hol VBO) geldt dit "liever een andere opleiding volgen" de belangrjikste reden is of

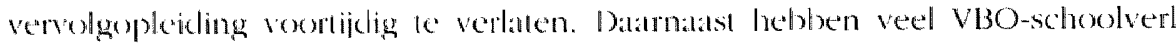
nog een andere - nich nader gespeciliceetele - reden. Opvallend zijn hier overiger verschillen tussen he MAVO en het VBO. Schoolverlaters van het MAVO verlaten valier chan schoolverlaters van het VBO de vervolgopleiding voortijdig onclat ze do volgopleidling oninteressint vinden, liever gaton werken of te weinig motivatie hel Verder is opvallend dat veet schoolverlaters van de sector VBO economie zegg weing motivatie te heblen om de vervolgopleiding af te maken.

Tibed 2.8 latal de bestemming gien van MAVO- en VBO-schoolvertaters die de ver opleiding in hed secundair beroepsonderwijs in het exerste leerjatr voortijdig he

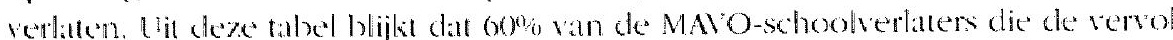


startkwalificatie doorgestroomd naar de arbeidsmarkt en $10 \%$ heeft een andere bestemming. Voor VBO-ers geldt dat $44 \%$ is overgestapt naar een andere opleiding, $44 \%$ is ingestroomd op de arbeidsmarkt en $11 \%$ heeft een andere bestemming. Opvallend voor het VBO is dat met name veel uitvallers van de sector VBO economie na het voortijdig verlaten van de vervolgopleiding in het eerste leerjaar kiezen voor de arbeidsmarkt. verder geldt dat relatief veel uitvallers van de sector VBO gezondheidszorg een andere bestemming hebben (onbetaald werk of andere situatie).

Tabel 2.8

Bestemming van MAVO en VBO-schoolverlaters die de vervolgopleiding voortijdig hebben verlaten

$\begin{array}{lccc} & \text { Studie/BBL } & \text { Arbeidsmarkt } & \begin{array}{c}\text { Onbetaald werk of } \\ \text { andere bestemming } \\ \%\end{array} \\ \text { MANO } & \% & \% & 10 \\ \text { VBO } & 60 & 30 & 11 \\ \text { VBO Landbouw } & 44 & 44 & \\ \text { VBO Techniek } & & & 0 \\ \text { VBO Economie } & 31 & 69 & 26 \\ \text { VBO Gezondheidszorg } & 58 & 42 & \\ \text {. = te weinig warnemingen } & 42 & & \end{array}$

\section{Kennis en vaardigheden}

Om de doorstroming natar het secundair beroepsonderwijs goed te laten verlopen is het van belang clat MAVO- en VBO-schoolverlaters in de opleicling relevante kwalificaties hebben opgedaan die aansluiten bij de vervolgopleiding. De vratag is in hoeverre het MAVO en het VBO schoolverlaters voorziet van kennis en valardigheden die relcvant

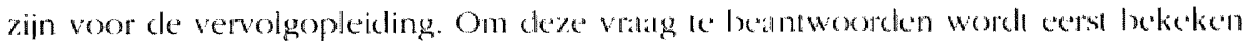
welke kennis en vatardigheden deor schoolvarlaters veet worden getmikt in ke vervolgopleading. Vervolgens worde alangegeven of de\% kennis en vaardigheden voldoende aan bod zijn gekomen in de MAVO-of VI3O-opleiding.

Tabel 2.9 gaat in op het gebruik van kennis en vaardigheden in de vervolgopleiding. Weergegeven is het atandeel MAVO- en VBO-schoolverlaters dal veel gelorukk maakl van

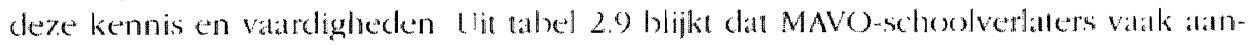
geven in de vervolgopleiding veel gelsuik te maken van de vatardigheelen \%elfstandig werken. communicatieve vardigheden, samenwerken en natuweurig werken catindeel tenminste $80 \%$. Hel atandeel MAVO-schoolverlatters dal zegt veel geloruik le maken van rekenvalardigheden en computervaardigheden in cle vervolgopleicling is datrentegen vrij laag (respectievelijk $50 \%$ en $65 \%$ ).

Ook voor VBO-schoolverlaters geldt dat het merendeel in de vervolgopleiding vecel gebruik makkt van zelfstandig werken, comnunicatieve valardigheden, samenwerken en nauwkeurig werken. Hel andeel schoolverlaters dat a angeef veel gebruk le maken van zelfstandig werken en nauwkeurig werken is bij het VBO hoger dan l ij luet MAV(). 
deze kennis en vaardigheden. Voor communicatieve vaardigheden geldt dat met na schoolverlaters van de sector VBO gezondheidszorg vaak zeggen veel gebruik hier te maken in de vervolgopleiding, terwijl schoolverlaters van de sector VBO techniek VBO economie dit minder vaak aangeven. Daarnaast zijn er nog enkele verschillen sen de sectoren van het VBO in het gebruik van kennis en vaardigheden in de vervo opleiding. Studieplanning en informatie verzamelen worden door schoolverlaters de sector gezondheidszorg het vaakst gebruikt in de vervolgopleiding, terwijl rek vaardigheden en computervaardigheden minder vaak relevant zijn voor schoolverla van deze sector. Voor rekenvaardigheden geldt dat deze in de vervolgopleiding vaakst worden gebruikt door schoolverlaters van de sector VBO techniek en com tervaardigheden worden het vaakst gebruikt door schoolverlaters van de sector $\mathrm{V}$ economie.

Tabel 2.9

Aandeel MAVO- en VBO-schoolverlaters dat veel gebruik maakt van kennis en vaardigheden in vervolgopleiding*

$\begin{array}{ccccc}\text { MAVO } & \text { VBO } & \begin{array}{c}\text { VBO } \\ \text { Techniek } \\ \%\end{array} & \begin{array}{c}\text { VBO } \\ \text { Economie } \\ \%\end{array} & \begin{array}{c}\text { VBO } \\ \text { Gezondzoi } \\ \%\end{array} \\ \% & \% & & & \\ 81 & 86 & 89 & 83 & 85 \\ 80 & 72 & 61 & 72 & 83 \\ 81 & 79 & 80 & 79 & 80 \\ 70 & 66 & 64 & 62 & 71 \\ 74 & 62 & 48 & 65 & 74 \\ 70 & 69 & 53 & 79 & 75 \\ 50 & 39 & 69 & 39 & 12 \\ 65 & 54 & 52 & 67 & 46 \\ 80 & 86 & 92 & 82 & 82\end{array}$

* = niel gevaragd voor VBO landboum

MAVO- en VBO-schoolver]aters is vervolgens gevraagd aan welke kennis en vaaro heden in cle algesloten opleiding meer alandacht besteed had moet worden. Tabel 2 latat zien welk deel van de schoolverlaters vind dat in de afgesloten opleiding meer a dacht moet worden besteed an de verschillende kennis en vardigheden.

Voor zowel MAVO-als VBO-schoolverlaters geldt dat zellstandig werken het vat word genoemd als vatarligheid watrain in de afgesloten opleiding meer aanda besteed had moeten worden. Dit is vooral belangrijk omdat eerder is angegeven MAVO- en VBO-schoolverlaters zelfstandig werken veel gebruiken in de vervo opleiding. Door in de MAVO- en VBO-oplesiding meer alandach te besteden aan zeltstandig uitvoeren van werkzaambeden door leerlingen kan de aansluiting met secundair beroepsonderwijs worden verbeterd. Daarnaast blijkt dar VBO-ers valak $z$ gen dat in de afgesloten opleiding meer aandacht had moeten worden besteed communicatieve vatardigheden. Dit geldt met name voor schoolverlaters van de sed VBO gezondheidszorg. Communicatieve vaardigheden zijn vooral voor schoolverlat 
deze vaardigheden in de vervolgopleiding. Opvallend is verder dat MAVO-schoolverlaters vaak aangeven dat computervaardigheden meer aandacht verdienen in de opleiding. VBO-schoolverlaters geven niet of nauwelijks aan dat computervaardigheden in de opleiding te weinig aan bod zijn komen. Voor schoolverlaters van de sectoren VBO techniek en VBO gezondheidszorg geldt dat in de opleiding meer aandacht voor taalvaardigheid wenselijk is. MAVO-schoolverlaters vinden vaak dat taatvaardigheid voldoende aan bod is gekomen in de afgesloten opleiding.

Tabel 2.10

Aandeel MAVO- en VBO-schoolverlaters dat aangeeft dat in de gevolgde opleiding meer aandacht aan kennis en vaardigheden had moeten worden besteed*

\begin{tabular}{|c|c|c|c|c|}
\hline MAVO & VBO & $\begin{array}{c}\text { VBO } \\
\text { Techniek }\end{array}$ & $\begin{array}{c}\text { VBO } \\
\text { Economie }\end{array}$ & $\begin{array}{c}\text { VBO } \\
\text { Gezondzorg }\end{array}$ \\
\hline$\%$ & $\%$ & $\%$ & \% & $\%$ \\
\hline
\end{tabular}

Kennis en vaardigheden

Zelfstandig werken

Communicatieve vardigheden I

Samenwerken

Studieplanning

Informatie verzamelen

Taalvaardigheid

Rekenvaardigheden

Computervaardigheden

Nauwkeurig werken

28

0

9

16

2

4

5

23

2

34
26
3
9
7
14
6
1
0

31
24
4
4
6
18
12
1
0

39
23
4
16
10
4
3
1
1

35

* = niet gevraagd voor VBO landbouw

\section{Examenvakken en de aansluiting met de vervolgopleiding}

Tot slot van dit hoofdstuk wordt bekeken hoe MAVO- en VBO-schoolverlaters de atansluiting tussen de gevolgde opleiding en de vervolgopleiding zelf ervatren. Tabel 2.11 geeft het oordeel van schoolverlaters over de mate waarin de gevolgde examenvakken aansluiten bij de vervolgopleidling. Uit deze tabel blijkt dat MAVO- en VBO-schoolverlaters wat dit betreft gemiddeld genomen niet van elkatr verschillen. Meer dan driekwant van de MAVO- en VBO-schoolverlaters zegl dat de examenvakken uil de gevolgcle opleiding voldoende tol goed alansluiten bij cle vervolgopleiding. Well blijkt dat dit aandeel gemiddeld hoger is voor schoolvertaters van de sector VIBO gezondheidszorg en gemiddeld lager is voor schoolverlaters van de sector V13O economie

De kans dat de gevolgde examenvakken voldoende tor goed alansluiten bij de vervolgopleiding is ook multivariaat geanalyseerd. Uit model 1 van tabel 2.11 blijkl clat schoolverlaters van de sectoren VBO economie en VBO gezondheidszorg slatistisch significant afwijken van schoolverlaters van het MAVO wat betreft de mate watrin de gevolgde examenvakken aansluiten bij de vervolgopleiding. Wanneer in model 2 word gecorrigeerd voor achtergrondkenmerken en het behaalde examenniveau van schosolverlaters verdwijnt het negatieve effect bij VBO economie. Het blijkt dal schoolverlatters die op het laagste niveau examen hebben gedaan vinden dat de examenvakken minder 
de sterkte van het effect behoorlijk is gestegen in model 2 . Het effect bij de sector $\mathrm{V}$ gezondheidszorg wordt versterkt na toevoeging van achtergrondkenmerken en behaalde examenniveau van schoolverlaters.

Tabel 2.11

De kans dat de examenvakken voldoende tot goed aansluiten bij de vervolgopleiding

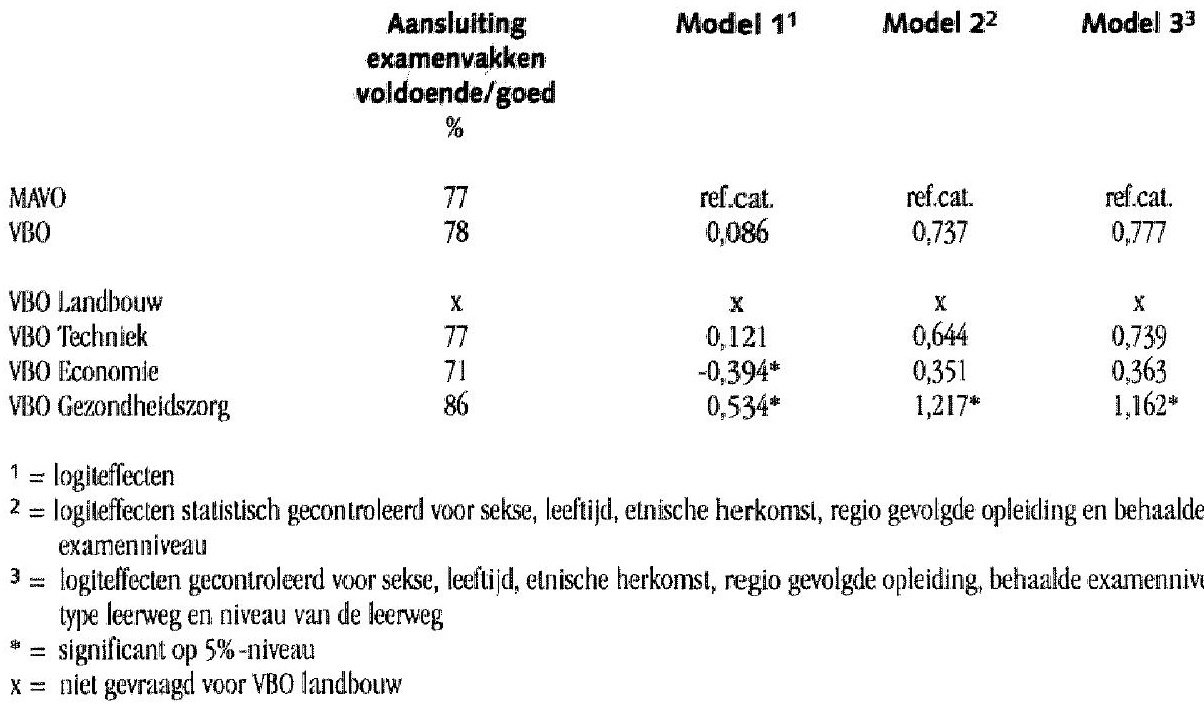

In model 3 waar is gecorrigeerd voor het type leerweg en het niveau van de leerwe de vervolgopleicling verandert weinig. De sterkte van de effecten zijn vrijwel gelijk die van model 3 . Overigens blijkt wel dat zowel het niveau van de vervolgopleiding de leerweg van invloed zijn op het oordeel van schoolverlaters over de aansluiting sen de gevolgde examenvakken en de vervolgopleiding. Schoolverlaters die doors men naar een opleiding op niveau $3 / 4$ zeggen significant vaker dat de gevol examenvakken voldoende tot goed aansluiten bij de vervolgopleiding dan schoolve ters die doorstromen naar een opleiding op niveau $1 / 2$. Verder geven schoolverla die kiezen voor de BOL significant vaker aan dat de examenvakken aansluiten bij vervolgopleiding dan schoolverlaters die kiezen voor de BBL.

In tabel 2.12 is het subjectieve oordeel van schoolverlaters over de aansluiting tussen gevolgcle opleiding en de vervolgopleiding weergegeven. Hieruit komt opnieuw n voren dat schoolverlaters van de sector VBO gezondheidszorg het valakst positief delen over de aransluting met de vervolgopleiding: $84 \%$ geeft aan dat de aansluiting sen de gevolgde opleiding met de vervolgopleiding voldoende tot goed Schoolverlaters van de sector VBO techniek zijn wat dit betreft het minst positief: slec $68 \%$ zegt de aansluiting met de vervolgopleiding voldoende tor goed te vinden. Van schoolverlaters van het MAVO en VBO economie geeft ongeveer driekwart aan de a sluiting tussen gevolgde opleidling en vervolgopleiding voldoende tot goed te vind 


\section{De kans dat de gevolgde opleiding voldoende tot goed aansluit bij de vervolgopleiding}

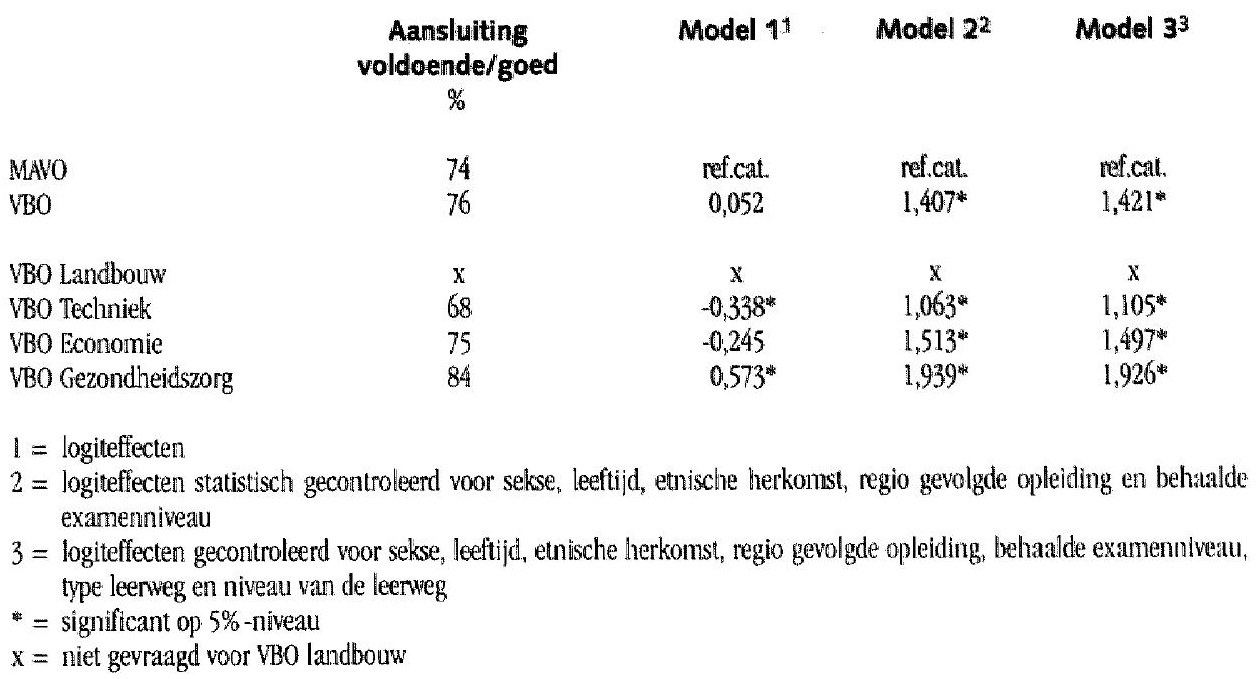

De kans dat de aansluiting tussen de gevolgde opleiding en de vervolgopleiding voldoende tot goed wordt beoordeeld is multivariaat geanalyseerd. Model 1 van tabel 2.12 laat zien dat de gevonden verschillen tussen het MAVO enerzijds, en de sectoren VBO techniek en VBO gezondheidszorg anderzijds statistisch significant zijn. In model 2 is zowel voor het gehele VBO als de verschillende sectoren het effect sterk toegenomen ten opzichte van model 1 . In dit model verschillen alle sectoren van het VBO in positieve zin significant van het MAVO. Dit wijst er op dat wanneer eenmaal rekening is gehouden met het feit dat VBO-schoolverlaters doorgaans op een lager niveau examen hebben behaald zij positiever oordelen over de aansluiting tussen de gevolgde opleiding en de vervolgopleiding dan MAVO-schoolverlaters.

Deze sterkte van de effecten bij het VBO blijven vrijwel ongewijzigd als in mockel 3 wordt gecorrigeerd voor het type leerweg en het niveau van de leerweg in de vervolgopleiding. Overigens geldı daarbij dat schoolverlaters die verder gaan leren in de BOL. vaker vinden dat de gevolgde opleiding voldoende tor goed aansluit bij de vervolgopleiding dan schoolverlaters die verder gaan leren in de BBL. Het niveau van do vervolgopleiding speelt verder geen rol bij het oordeel van schoolverlaters over de: aansluiting tussen gevolgde opleiding en vervolgopleiding.

\subsection{Samenvatting}

In dit hoofdstuk is de instroom in hel secundair beroepsonderwiis van schoolverlaters van het $V B O$ en hel MAVO vergeleken. Allereerst is geconstateerd dat MAVO-schoolverlaters gemiddeld genomen op een hoger niveau examen hebben gedaan dan VBOschoolverlaters. Leerlingen van het VBO kunnen examen doen op vier versehillende niveaus, oplopend van A-niveau (het lagste niveau) tot D-niveau (het hoogste nivcau) Leerlingen van het MAVO kunnen slechts examen doen op twee niveaus: $\mathrm{C}$-niveau en 
schoolverlaters om verder te gaan leren, op welk niveau ze verder gaan leren en voor welke leerweg ze kiezen. Uit onze analyses blijkt dat met name schoolverlaters die of een laag niveau examen hebben gedaan (A- of B-niveau) besluiten niet verder te gaan leren en het onderwijs te verlaten. Verder komt naar voren dan schoolverlaters met een diploma van A- of B-niveau op een lager niveau instromen in het secundair beroeps. onderwijs dan schoolverlaters met een diploma van hoger niveau. Daarnaast kiezen schoolverlaters met een diploma van A- of B-niveau minder vaak voor de BOL.

De aansluiting tussen de gevolgde opleiding en de vervolgopleiding in het secundai beroepsonderwijs is voor VBO-schoolverlaters doorgaans even goed als voor MAVO. schoolverlaters. Een belangrijke indicatie hiervoor is de omvang van de voortijdige uitval in het eerste leerjaar van de vervolgopleiding in het secundair beroepsonderwijs Schoolverlaters van cle sector VBO techniek blijken minder vaak dan MAVO-schoolverlaters de vervolgopleiding voortijdig te verlaten in het eerste leerjaar. Voor de andere sectoren van het VBO geldt dat de omvang van de uitval van schoolverlaters in de vervolgopleicling vrijwel gelijk is aan die het MAVO. Daarnaast is bekeken in welke mate MAVO- en VBO-schoolverlaters over kennis en vaardigheden beschikken die veel worden gebruikt in de vervolgopleiding. Het merendeel van de MAVO- en VBO-schoolverlaters zegt in de vervolgopleiding veel gebruik te maken van de vaardigheder zelfstandig werken, communicatieve vaardigheden, samenwerken en nauwkeurig werken. Samenwerken en nauwkeurig werken zijn volgens MAVO- en VBO-schoolverlaters doorgaans voldoende aan bod gekomen in de gevolgde opleiding. Voor zelfstandig werken geldt echter dat MAVO- en VBO-schoolverlaters vaak aangeven dat hieraan te weinig aandacht is besteed in de afgesloten opleiding. Verder geldt voor schoolverlater van de sector VBO gezondheidszorg dat communicatieve vaardigheden te weinig aandacht hebben gekregen in de opleiding. Daarnaast vinden MAVO-schoolverlaters vee vaker dan VBO-schoolverlaters dat computervaardigheden onvoldoende aan bod zijr gekomen in de afgesloten opleiding. Schoolverlaters van de sectoren VBO techniek er VBO gezondheidszorg zeggen vaak dat in de opleiding meer aandacht had moeter worden besteed an taalvardigheid.

Ten slotte is ingegaan op het oordeel van schoolverlaters over de aansluiting tussen de gevolgde opleiding en de vervolgopleiding in het secundair beroepsonderwijs Schoolverlaters van de sector VBO economie vinden minder vaak dat de examenvakken voldoende tot goed aansluiten bij de vervolgopleiding dan MAVO-schoolverlaters Dit kan echter worden toegeschreven aan het examenniveau dat schoolverlaters hebben gevolgd. Schoolverlaters die een lager examenniveau hebben gevolgd vinden min der vaak dat de examenvakken aansluiten bij de vervolgopleiding dan schoolverlater die op een hoger niveau examen hebben gedaan. Voor schoolverlaters van de sector VBO gezondheidszorg geld dat ze vaker dan MAVO-schoolverlaters vinden dat de examenvakken voldoende tot goed aansluiten bij de vervolgopleiding. Dit verschil word nog sterker wanneer rekening wordt gehouden met achtergrondkenmerken en he behaalde examenniveau van schoolverlaters.

Ook wal betreft de aansluiting tussen de gevolgde opleiding en de vervolgopleiding zijn schoolverlaters van de sector VBO gezondheidszorg positiever dan MAVO-schoolverlaters. Schoolverlaters van de sector VBO gezondheidszorg vinden deze aansluiting 
den met achtergrondkenmerken van schoolverlaters, het behaalde examenniveau, de keuze van de leerweg en het niveau van de vervolgopleiding dan vinden, naast schoolverlaters van de sector VBO gezondheidszorg, ook schoolverlaters van de sectoren VBO techniek en VBO economie vaker dan MAVO-schoolverlaters dat de opleiding voldoende tot goed aansluit bij de vervolgopleiding. 


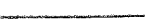




\section{De aansluiting tussen behaalde kwalificaties en gevonden functie voor schoolverlaters van de BOL en de BBL}

In het Nederlandse onderwijsbeleid wordt sinds een aantal jaren veel waarde gehecht aan beroepsgerichte vaardigheden bij het startbekwaam maken van jongeren tijdens de overgang van school naar werk. Dit heeft er mede toe geleid dat eind jaren negentig van de vorige eeuw in het secundair beroepsonderwijs - als gevolg van de komst van de Wet Educatie en Beroepsonderwijs (WEB) - een nieuwe kwalificatiestructuur is ingevoerd waarin een onderscheid wordt gemaakt tussen de beroepsopleidende leerweg (BOL) en de beroepsbegeleidende leerweg (BBL). Beide leerwegen kennen vier niveaus. Binnen ieder niveau worden gediplomeerde schoolverlaters van de BOL en de BBL formeel als gelijkwaardig beschouwd. De leerwegen verschillen echter van elkaar als het gaat om het curriculum. Binnen de BBL ligt de nadruk veel meer dan bij de BOL op het aanleren van beroepsgerichte vaardigheden via de beroepspraktijk. De verplichte beroepspraktijkcomponent bestaat bij de BBL uit minstens $60 \%$ van de opleiding; bij de BOL uit minstens $20 \%$ en maximaal $60 \%$. De rest van de tijd wordt besteed aan de theoriecomponent van de opleiding.

De vraag is of het verschil in aandacht voor beroepsgerichte vaardigheden via de beroepspraktijk tussen de BOL en de BBL gevolgen theeft voor de arbeidsmarktintrede van beide groepen schoolverlaters. Daartoe is in dit hoofdstuk allereerst nagegaan in hoeverre de aansluiting tussen de behaalde kwalificaties en de gevonden functie (afgemeten aan de kans om al dan niet te werken in een functie waarvoor men is opgeleid) verschilt tussen de BOL en de BBL. Gezien de minder sterke nadruk op het a anleren van beroepsgerichte vaardigheden via de praktijk bij de BOL wordt verwacht dat daar de ansluiting tussen de behaalde kwalificaties en de gevonden functie geringer is. Bovendien is bestudeerd waarom sommige schoolverlaters van de BOL en de BBL niet werkzaam zijn in een bij de opleiding aanslutende functic en of zij, indien mogelijk, eventueel wel in een functie willen werken waarvoor zij zijn opgeleicl.

Vervolgens is onderzocht in hoevere het al dan niet werkzaam zijn in een functic walavoor men is opgeleid gevolgen heeft voor de arbeidsmarkipositie en in we/ke matte daarin verschillen bestaan tussen de BOL en de BBL. Verondersteld wordt dat schoolverlaters die in een functie buiten de gevolgde opleiding werkzaam zijn, cen mincler goede arbeidsmarktpositie hebben (bijvoorbeeld in termen van beloning), minder hoge verwachtingen hebben over hun looplaanperspectiel en minder tevreden zijn over zowel de verlaten opleiding als de gevonden functie Tevens wordt voorspeld dal de negatieve arbeidsmarkteffecten van een gebrekkige aansluiting tussen de helhatcle kwalificaties en de gevonden functic sterker zijn voor schoolverlaters van de $|3| 3 \mid$, juist vanwege de sterkere aandacht daar voor beroepsspecifieke vaardigheden die buiten het eigen beroependomein veel minder productief kunnen worden aangewend.

De gegevens die in dit hoofdstuk zijn geanalyseerd komen van maximatal $3.652 \mathrm{schos}$. verlaters van de $B O L$ en de BBL die in het schooljaar $2000 / 2001$ het diploma helblen behaald. Her gatat hier dus om schoolverlaters die allen hun beroepsopleiding in de 
vergelijking worden gemaakt van de arbeidsmarktpositie tussen schoolverlaters va BOL en de BBL. 16

De analyse is uitgevoerd met behulp van variantie-analyse (ANOVA/MCA). ${ }^{17}$ Ir gepresenteerde tabellen zijn verschillen in gemiddelden tussen groepen van school laters (naar onderwijssoort en opleidingssector ${ }^{18}$ ) op een bepaald arbeidsmarkt merk weergegeven. Daarbij worden steeds twee gemiddelden getoond: de rechtstr waargenomen gemiddelden (ongecontroleerd) en de geschatte gemiddelden die den verkregen nadat rekening is gehouden met de invloed van andere relevante schillen tussen schoolverlaters (bijvoorbeeld naar sekse of vooropleiding) verschillen tussen de gecontroleerde gemiddelden zijn in de regel kleiner dan de schillen tussen de ongecontroleerde gemiddelden. Dit betekent dat de waargeno verschillen gedeeltelijk zijn toe te schrijven aan verschillen in andere relevante merken van schoolverlaters (zoals de eerder genoemde verschillen in sekse en v opleiding). Dit komt ook tot uitclrukking in de èta, een maat die de sterkte van verband tussen de onderwijssoort, respectievelijk de opleidingsector en het arbe marktkenmerk alangeeft. Deze is over het algemeen kleiner in de analyse waarbij w gecontroleerd voor andere relevante kenmerken van schoolverlaters.

\subsection{Wie hebben geen aansluitende functie?}

In tabel 3.1 is weergegeven hoeveel procent van de schoolverlaters van het secun beroepsonderwijs niet werkzaam is in een bij de opleiding aansluitende functie. Da is een uitsplitsing gemaakt naar het niveau en de leerweg (tezamen onderwijss genoemdl) en de opleidingssector die is gevolgd. Iemand is niet werkzaam in een sluitende functie als hij of zij niet werkt in een functie waarvoor hij of zij is opgele

Uit deze tabel komt naar voren dat in totaal $22 \%$ van de schoolverlaters niet werkz is in een aansluitencle functie. Er zijn echter grote verschillen naar onderwijssoort zijn BBL'ers - ongeach niveau - minder valak in een niet-aansluitende functie w zalam dan BOl.ers. Datamast hebben schoolverlaters met een opleiding op niveau - ongeacht leerweg - minder valak een niet-aansluitende functie dan degenen met opleiding op nivealu 1/2. Hel verlband tussen de gevolgde onderwijssoorl en het cleel schoolverlaters dat niet werkzalam is in een alansluitende functie is redelijk (èta $=0,20)$. Verschillen natr opleidingssector zijn nog sterker aanwezig. De bedratgl hier 0,24. Mel name schoolverlaters van de sectoren landbouw en econo werken vaker in een niel-atunsluitende lunctie. Voor beide sectoren is dit bij eend van de schoolverlaters het geval. De opleidingssector gezondheidszorg kent daare gen hel laigste percentige schoolverlaters dat niet werkzaam is in een aanslute functie: $12 \%$.

to In tegenstelling lor de vergelijking tusisen de BOL ten de BBL zoals gepresenteed in hoofdstuk

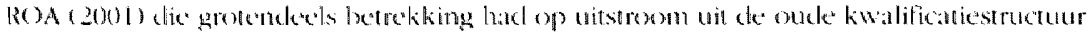

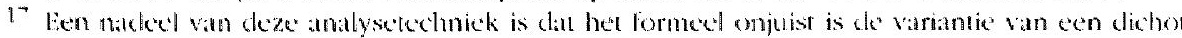

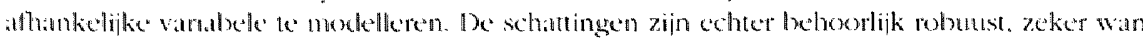

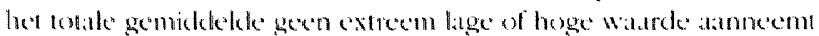

18 Als het gatat om kenmerlien kan de arbeidsmatkipositie van schoolverlaters worden ook verset 
Tabel 3.1

Schoolverlaters die niet werkzaam zijn in een bij de opleiding aansluitende functie naar onderwijssoort en opleidingssector, ongecontroleerd (O) en gecontroleerd (G) voor de invloed van andere kenmerken van schoolverlaters ${ }^{a}$

Totaal

\section{Aansluitende \\ functie: nee}

$\%$

\section{Onderwijssoort}

BOL niveau $1 / 2$

BOL. niveau $3 / 4$

Bol. niveau $3 / 4$

G
35

BBL niveau $1 / 2$

BBL niveau $3 / 4$

0

18

BBL niveau $3 / 4$

$$
\text { G }
$$

Eta

0

\section{Opleidingssector}

Landbouw

Techniek

echniek

Economie

G

Gezondheidszorg

0

a = gecontroleerd woor de invloed van leeftijd, sekse, etniciteit, wooropleiding, belatald werk/stage-ervaring, intledewerk loosheid, bedrijlsgrootte en publieke sector. Bij onderwijssoort is de invlowd van opleidingssector uitgeschakeld; bij opleidingssector die van onderwijssoort

क significant op $1 \%$-niveatu

Als rekening wordt gehouden met allertei relevante kenmerken van schoolverlatcrs, dan nemen de verschillen in het percentage schoolverlaters met en nict-atanshitende functie nat onderwijssoort voor een deel af. Wat betrelt de gevolgde onderwijssourt geld dat in het ongecontroleerde geval het maximale verschil $29(40-11$ ) procentpunten bedraggt tegenover $21(35-14)$ procentpunten in hel gecontrolecte geval. I) (* $\%$ reductie komt ook tol uitdrukking in de mate van samenhang. De cata datt van 0,20 in 
van de waargenomen verschillen in het percentage schoolverlaters met een niet-: sluitende functie naar onderwijssoort versterkt door verschillen in andere relevante merken van schoolverlaters. Met betrekking tot de gevolgde opleidingssector wordt soortgelijk beeld geconstateerd. Ook hier nemen het maximale percentageverschi de mate van samenhang af na controle voor allerlei kenmerken van schoolverlaters

Als het gaat om deze andere kenmerken van schoolverlaters, dan valt met name de op van betaald werk/stage-ervaring. Schoolverlaters van de BOL en de BBL die tijc de opleiding veel ervaring hebben opgedaan met stages en/of betaald werk heb verricht in het kader van een leerarbeidsovereenkomst zijn minder vaak werkzaar een functie die niet aansluit bij de behaalde kwalificaties dan schoolverlaters die we ervaring met de beroepspraktijkcomponent hebben opgedaan gedurende de $\mathrm{BOL}$ BBL-opleidling. Daarnaast is de lengte van de intredewerkloosheid van bel Schoolverlaters die lang werkloos zijn geweest in de periode tussen het verlaten van opleiding en het moment van ondervraging hebben een grotere kans om werkzaar zijn in een niet-aansluitende functie dan degenen die kort werkloos zijn geweest in c periode. Tot slot hangen twee organisatiekenmerken samen met het hebben van functie die niet aansluit bij de behaalde kwalificaties. Schoolverlaters die bij een $\mathrm{g}$, bedrijf werken hebben vaker een niet-aansluitende functie, terwijl degenen die ir publieke sector werkzaam zijn juist minder vaak een niet bij de opleiding aansluite functie hebben.

\subsection{Waarom werkt een aantal schoolverlaters niet in een aansluitende functie?}

Vervolgens is nagegaan wat voor redenen schoolverlaters noemen voor het feit da niet in een functie werken walarvor ze zijn opgeleid. Deze redenen kunnen zeer di zijn zoals blijkt uit tabel 3.2. Allereerst zijn er twee redenen die samenhangen me directe aansluitingsproblematiek. Ongeveer eenvijfde van de schoolverlaters geeft dat zij geen werk hebben kunnen vinden dat aansluit bij de behaalde kwalificaties. percentage is het hoogst onder schoolverlaters die een opleiding op BOL niveau heblben gevolgd $(26 \%)$ en het laagst onder degenen met een opleiding op BBL niv 1/2 (10\%). Voor ongeveer eenderde kunnen deze verschillen worden toegeschre aan verschillen in achtergrondkenmerken tussen schoolverlaters (de èta daalt imn van 0,16 naar 0,09 ). Ook tussen opleidingssectoren zijn er aanzienlijke verschillen. geeft $47 \%$ van de schoolverlaters van de sector gedrag en maatschappij aan geen $n$ gevonden te heblen dat aansluit bij de behaalde kwalificaties, terwijl het overeenk stige percentage bij technisch opgeleide schoolverlaters $17 \%$ bedraagt.

Een groter deel van de schoolverlaters - 34\% om precies te zijn - geeft aan op vrijw ge basis niet werkzaam te zijn in een aansluitende functie: zij willen niet (meer) wer in de richting waarvoor ze zijn opgeleid. Opnieuw is er variatie naar onderwijssoor opleidingssector, matar de verschillen zijn hier wat kleiner. Wat betreft de gevol onderwijssoort komt naar voren dat vooral schoolverlaters van BBL niveau $1 / 2$ en niveau $3 / 4$ niet (meer) willen werken in de richting waarvoor ze zijn opgeleid. betrekking tot de gevolgde opleidingssector geld dat met name schoolverlaters var sectoren economie en landbouw dat niet (meer) willen. 
Tabel 3.2

Redenen waarom schoolverlaters niet werkzaam zijn in een bij de opleiding aansluitende functie naar onderwijssoort en opleidingssector, ongecontroleerd $(O)$ en gecontroleerd $(G)$ voor de invloed van andere kenmerken van schoolverlaters ${ }^{\mathrm{a}}$

Totaal

\section{Onderwijssoort}

BOL niveau $1 / 2$

BOL niveau $3 / 4$

BBL. niveau $1 / 2$

BBL niveau $3 / 4$

Eta

\section{Opleidingssector}

Landbouw

Techniek

Economie

Gezondheidszorg

Gedrag en maatschappij

Ela

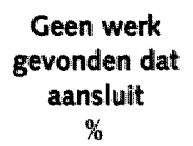

21

19
22
26
23
10
14
14
17
$0,16^{\text {** }}$
$0,09^{\text {** }}$

$0,16^{\text {*** }}$

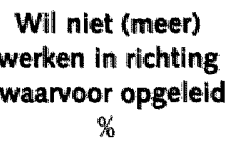

34

27

21

36

37

41

42

25

29

$0,12 *$

$0,15^{*}$
Salaris valt tegen

$\%$

14

10

9

16

17

27

25

15

14

$0,14^{\text {*** }}$

$0,13^{\text {*we }}$

10
9
16
17
27
25
15
14
$0,14^{\text {twat }}$
$0,13^{* 4 *}$

4

0,15 
Tabel 3.2 (vervolg)

Redenen waarom schoolverlaters niet werkzaam zijn in een bij de opleiding aansluitende functie naar onderwijssoort en opleidingssector, ongecontroleerd $(O)$ en gecontroleerd $(G)$ voor de invloed van andere kenmerken van schoolverlaters ${ }^{\mathrm{a}}$

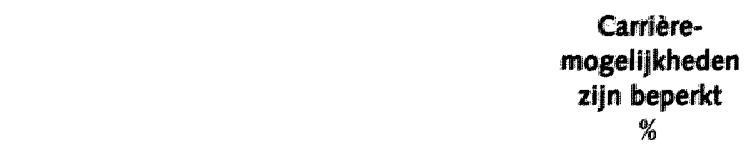

Totaal

\section{Onderwijssoort}

Bol, niveau $1 / 2$

BOL, niveau $3 / 4$

BBL niveau $1 / 2$

BBL. niveau 3/4

Eta

\section{Opleidingssector}

l.andbouw

Techniek

Economie

Gezondhetdszorg

Gedrag en maatschappi

Eta
14

11

\section{Werktijden Werk is lichamelijk of geestelijk te zwaar \\ $\%$}

4

3

2

3

3

9

8

7

7

$0,12^{* *}$

$0,10^{* *}$

$\begin{array}{llll}0 & 0,09 & 0,08 & 0,12^{* *} \\ \mathrm{G} & 0,04 & 0,11 & 0,10^{* * *}\end{array}$


Beperkte carrièremogelijkheden worden eveneens door $14 \%$ van de schoolverlaters genoemd als een reden voor het hebben van een functie die niet aansluit bij de behaalde kwalificaties. De verschillen tussen onderwijssoorten en opleidingssectoren zijn vrij beperkt. Met betrekking tot de gevolgde onderwijssoort bedraagt het maximale verschil $10 \%$ (dat wil zeggen het percentageverschil tussen BBL niveau 3/4 en BOL. niveau 1/2). Wat betreft de gevolgde opleidingssector is het maximale verschil $13 \%$. In beide gevallen zijn de gevonden verschillen niet significant.

Werktijden die niet bevallen worden door $11 \%$ van de schoolverlaters als een reden genoemd voor het werken in een niet-aansluitende functie. Verschillen tussen onderwijssoorten en opleidingssectoren zijn daarbij nauwelijks aanwezig. Wat betreft de gevolgde onderwijssoort geldı dat schoolverlaters van BBL niveau $1 / 2$ het vaakst aangeven dat een reden waarom zij niet in een bij de opleiding passende functie werkzaam zijn, te maken heeft met werktijden die niet bevallen. Wat betreft de gevolgde opleidingssector komt naar voren dat schoolverlaters die een opleiding in de sector gezondheidszorg hebben gedaan, het vaakst ontevredenheid met de werktijden als een reden opgeven voor het niet werken in een bij de behaalde kwalificaties aansluitende functie.

De overig genoemde redenen die zijn weergegeven in tabel 3.2 komen slechts in beperkte mate voor. Het gaat daarbij om functies waar geen mogelijkheden voor kinderopvang zijn, waar de werkdruk te hoog is en die lichamelijk of geestelijk te zwaar zijn. Wat de laatste twee redenen betreft blijkt dat deze vooral worden genoemd door schoolverlaters van de sector gezondheidszorg. De laatstgenoemde reden wordt ook relatief veel naar voren gebracht door schoolverlaters van de sector landbouw.

Tot slot is er een grote groep schoolverlaters die een in tabel 3.2 niet nader omgeschreven reden opgeeft waarom zij niet in een bij de behaalde kwalificaties aansluitende functie werkzaam zijn. Deze reden is hier niet nader omschreven vanwege de diversiteit van de antwoorden. Het gaat daarbij om redenen als 'ik ben werkzaam in het bedrijf van mijn vader', 'ik ga een eigen bedrijl starten', 'ik ben/voel me nog te jong' en 'ik hels gezondheidsproblemen'.

Ondanks het feit dat schoolverlaters met een functie warvoor ze niel zijn opgeleid veelal een duidelijke reden hiervoor noemen, betekent dit allerminsı dal zij nicı willen werken in een functie die aansluit bij de behaalde kwalificaties. Integendeel zelfs, ongeveer tweederde van de schoolverlaters die een functie heloben warvor $z$ nict zijn opgeleid wil eventueel wel werken in een aanslutende funclie (zie label 3.3). 19 Weliswaar zijn daarbij verschillen te constateren tussen onderwijssoonten en opleydingssectoren. Zo willen schoolverlaters van de BOL wat vaker eventueel wel werken in een funclie warvoor ze zijn opgeleid dan schoolverlaters van cle B13L. Evenzeer witlen schoolverlaters die een opleiding heb gevolgd in de sector landbouw of gedrag on

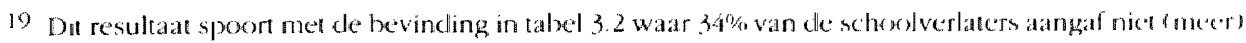

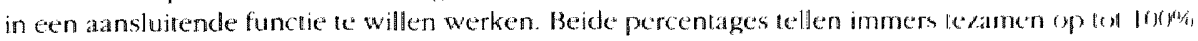
De verschillen nat onderwijssesont en opleidingssector lopen datentegen wel utecen tusan de 
Tabel 3.2 (vervolg)

Redenen waarom schoolverlaters niet werkzaam zijn in een bij de opleiding aansluitende functie naar onderwijssoort en opleidingssector, ongecontroleerd $(O)$ en gecontroleerd $(G)$ voor de invloe van andere kenmerken van schoolverlaters ${ }^{a}$

Totaal

\section{Onderwijssoort}

BOL, niveau $1 / 2$

BOL niveau $3 / 4$

BBL. niveau $1 / 2$

BBL. niveau $3 / 4$

Eta

$\begin{array}{ll}\begin{array}{l}\text { Opleidingssector } \\ \text { Landbouw }\end{array} & \mathrm{O} \\ & \mathrm{G} \\ \text { Techniek } & 0 \\ & \mathrm{G} \\ \text { Economie } & 0 \\ & \mathrm{G} \\ \text { Gezondherlsworg } & 0 \\ & \mathrm{G} \\ \text { Gedrag en malschippij } & 0 \\ & \mathrm{G} \\ \text { Lita } & 0 \\ & \mathrm{G}\end{array}$

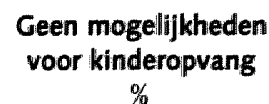

$\%$

0

Werkdruk
is te hoog
$\%$

4

41

48

52

40

41

37

34

41

35

0,08

0,12

$\mathbf{a}=$ gecontroleerd voor de inwloed wat leettijd, sekse, etniciteit, vooropleiding, betaald werk/stage-ervaring, intredewe loosheid, hedriffsgrootte en publicke sector. Bij onderwijssoort is de invloed van opleidingssector uitgeschakeld: opleidingssector die vall ondenwijsoont

mataschappij vaket eventueel wel werken in een functie die aansluit bij de behaal kwalificalties dan degenen met een technische opleidingsachtergrond. Voor een de hangen deze verschillen lussen onderwijssoorten en opleidingssectoren samen m andere relevante kenmerken van schoolverlaters, gezien het feit dat de èta's in h gecontrolleerde geval wat kleiner zijn. 
Tabel 3.3

Schoolverlaters die eventueel wel willen werken in een bij de opleiding aansluitende functie naar onderwijssoort en opleidingssector, ongecontroleerd (O) en gecontroleerd (G) voor de invloed van andere kenmerken van schoolverlaters ${ }^{a}$

Totaal

\author{
Wil eventueel wel werken \\ in aansluitende functie \\ o
}

\title{
Onderwijssoort
}

BOL niveau $1 / 2$

BOL niveau $3 / 4$

BBL niveau $1 / 2$

BBL niveau $3 / 4$

Eta

\section{Opleidingssector}

Landbouw

Techniek

Economie

Gezondheidszorg

Gedrag en maatschappij

Ela
65

65

67

69

68

58

61

57

56

$0,11^{*}$

$0,09^{*}$

G 75 74

G 59

0

63

G

63

63

G

67

65

G

81

0

76

0

$0,14^{\mathrm{m}}$

$0,10^{*}$

a = gecontroleerd woor de invloed van leeftijd, sekse, eniciteil, vooropleiding, betaald werk/stage-ervarlng, intredewerk loosheid, bedriflsgrootte en publieke sector. Bij onderwijssoort is de invloed van opleidingssector uitgeschakeld; bil opleidingssector die van onderwijssoort.

* = significant op $5 \%$-riveau

** = significant op $1 \%$-niveau

\section{3 $\overline{\mathrm{De}}$ arbeidsmarktpositie van schoolverlaters die niet werkzaam zijn in een aansluiten- de functie}

De veronderstelling dat het niet werkzaam zijn in een functie waarvoor men is opgcleid nadelige gevolgen heeft voor de arbeidsmarktpositie blijkt op grond van tabel 3.4 gro- 
en het bruto uurloon vergeleken tussen schoolverlaters met een aansluitende functie en schoolverlaters die niet in een aansluitende functie werkzaam zijn. Daarbij is een uitsplitsing gemaakt naar de verschillende onderwijssoorten. Met uitzondering van de kans op voltijd werk geldt dat - ongeacht onderwijssoort - schoolverlaters die niet werkzaam zijn in een functie waarvoor ze zijn opgeleid slechter af zijn dan degenen met een aansluitende functie. Zo heeft $84 \%$ van de schoolverlaters van BOL niveau $3 / 4$ die in een aansluitende functie werken vast werk tegenover $70 \%$ van degenen die niet werkzaam zijn in een aansluitende functie. De bijbehorende èta bedraagt 0,16. Ongeveer eenderde van deze samenhang kan worden toegeschreven aan andere relevante verschillen tussen schoolverlaters. Want eenmaal gecorrigeerd voor de invloed van deze verschillen is de èta 0,11 . Ook voor de overige onderwijssoorten geldt dat schoolverlaters met een niet-aansluitende functie minder vaak vast werk hebben dan schoolverlaters die in een aansluitende functie werkzaam zijn. De negatieve samenhang tussen een gebrekkige aansluiting en de kans op vast werk is niet sterker voor de BBL, zoals in het begin van dit hoofdstuk werd gesuggereerd. Op niveau $1 / 2$ is het verband weliswaar sterker bij de BBL dan bij de BOL (de èta's zijn respectievelijk 0,17 en 0,12), maar op niveau $3 / 4$ is het omgekeerde het geval (de èta's zijn daar 0,10 en 0,16 ). In de gecontroleerde analyse zijn cle èta's op beide niveaus zelfs kleiner bij de BBL dan bij de BOL.

Ook wat betreft verschillen in beloning is duidelijk te zien in tabel 3.4 dat schoolverlaters clie niet in een aansluitende functie werkzaam zijn mincler verdienen dan schoolverlaters met een aansluitende functie. Dit geldt wederom voor alle onderscheiden onderwijssoorten. Het grootste beloningsverschil wordt aangetroffen bij BOL niveau $1 / 2$. Het verschil in bruto-uurloon bedraagt hier $€ 0,69(6,96-6,27)$. De bijbehorende èta is 0,16 . Ook bij BOL niveau $3 / 4$ is een redelijk grote samenhang aanwezig tussen het al dan niet werkzaam zijn in een aansluitende functie en het bruto-uurloon. De èta bedraagt hier 0,12 . In beide gevallen is een flink deel van de beloningsverschillen toe te schrijven aan verschillen in andere kenmerken tussen schoolverlaters. Na controle voor deze schoolverlaterskenmerken zijn de èta's immers aanmerkelijk kleiner. Bij de BBL zijn cle beloningsverschillen op beide nivedus niet significant. Opnieuw is daarmee atangetoond dat de negatieve arbeidsmarkteffecten van een gebrekkige aansluiting tussen de behatalde kwalificatties en de gevonden functie niet sterker zijn voor schoolverlaters van de BBL. Juist het omgekeerde blijkt te gelden: BOLers kunnen de valardigheden die zij heblyen geleerd tijdens de opleiding buiten het eigen beroependomein minder producticf alinwenden dan BBL.ers.

Niel cokel de feitelijke arbeidsmarktpositie verschilt tussen schoolverlaters met een bij de opleveling atansluitende lunctie en degenen zonder aansluitende functie. maar ook het carriereperspectief loopt witeen (zie tabel 3.5). Dit geld overigens alleen voor schoolverlaters van de $130 \mathrm{~L}$. Nalar voren kom dat schoolverlaters die niet werkzaam zijn in een functie walarvor zij zijn opgeleid minder positief oordelen over hun carrièremogedijkheden dan schoolverlaters die in een functie werken waarvoor zij zijn gekwalificeerd. Bii BOL niveau $1 / 2$ hedraing het verschil in beoordeling $0.5(3.6-3,1)$ punten op cen schaal lopend van 1 tot en mel 5; bij BOL niveau $3 / 4$ bedralat het verschil 0.2 punten. De bijlehorende èa's zijn respectievelijk 0,16 en 0.06 . Ook als rekening wordr gehouden met allerlei kenmerken van schoolvetaners blift de samenhang tussen het al

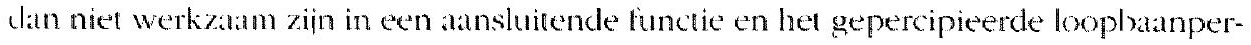


Tabel 3.4

Vast werk, voltijd werk en lbruto uurloon van schoolverlaters naar aansluitende functie per onderwijssoort, ongecontroleerd $(O)$ en gecontroleerd $(G)$ voor de invloed van andere kenmerken van schoolverlaters ${ }^{\mathrm{a}}$

$\begin{array}{ccc}\begin{array}{c}\text { Vast werk } \\ \%\end{array} & \begin{array}{c}\text { Voltijd werk } \\ \%\end{array} & \begin{array}{c}\text { Bruto uurloon } \\ €\end{array} \\ 74 & 65 & 6,69 \\ 79 & 66 & 6,96 \\ 79 & 66 & 6,78 \\ 68 & 64 & 6,27 \\ 68 & 63 & 6,56 \\ 0,12^{*} & 0,02 & 0,16^{* * 4} \\ 0,13^{*} & 0,03 & 0,05^{* *}\end{array}$

BOL niveau $3 / 4$

81

70

8,27

Aansluitende functie

Ja

$84 \quad 70$

8,45

BOL niveau $1 / 2$

0

G

0

0

G

Nee

70

7,92

73

72

71

7,90

Eta

G

66

$0,12^{\text {*ै* }}$

G

$0,11^{* * *}$

BBL niveau $1 / 2$

88

82

7,48

Aansluitende functie

Ja

90

82

7,58

89

7,70

Nee

G

76

81

7,07

G

82

83

6,54

$0,17^{* * *}$

84

0,08

G

$0,08^{\text {*** }}$

0,01

$0,18^{*}$

BBL niveau 3/4

94

78

9.50

Aansluitende functie

Ja

0

95

9,54

94

78

9,48

Nee

87

79

91

9,65

E.ta

G

$0,10^{\text {*** }}$

78
72

0,04

G

$0,04^{* \text { * }}$

0,00

0,02

a = gecontroleerd woor de invloed van opleidingssector, leeftijd, sekse, etniciteil, vooropleiding. betaald werk/stageterva ring, intredewerkloosheid, bedrijfsgrootte en publieke sector

$*=$ significant op $5 \%$-niveau 
Tabel 3.5

Loopbaanperspectief en tevredenheid van schoolverlaters naar aansluitende functie per onderw soort, ongecontroleerd $(O)$ en gecontroleerd $(G)$ voor de invloed van andere kenmerken van schoolverlaters ${ }^{\mathrm{a}}$

$\begin{array}{ccc}\begin{array}{c}\text { Goede carrière- } \\ \text { mogelijkheden }\end{array} & \begin{array}{c}\text { Tevreden met } \\ \text { huidige functie }\end{array} & \begin{array}{c}\text { Dezelfde opleidi } \\ \text { opnieuw kieze }\end{array} \\ \begin{array}{c}1-5 \\ \end{array} & 1-5 & \%\end{array}$

BOL niveau $1 / 2$

3,4

3,9

64

Aansluitende functie

Ja

3,6

4,1

74

3,6

3,1

4,1

76

Nee

3,0

3,6

50

G

$0,16^{* * *}$

3,6

46

Ela

0

$0,24 * *$

$0,22^{* *}$

$0,24^{* *}$

$0,21^{* * *}$

$0,31^{* *}$

BOL niveau 3/4

3,3

4,3

76

Aansluitende functie

Ja

3,3

4,1

83

3,3

Nee

3,1

4,1

3,6

83

0

3,1

$0,06^{\text {*** }}$

3,7

54

Eta

0

$0,07 *$

$0,22 * *$

56

G

3,4

4,3

74

Aansluitende functie

Ja

3,3

4,2

4,2

$0,30^{* *}$

$0,17^{* *}$

$0,27^{* *}$

Nee

3,4

3,5

3,8

3,5

0,06

3,8

$0,18^{* \text { * }}$

$0,20^{* * 4}$

79

78

53

Bta

0

0,03

3,9

82

BBL niveau 3/4

3,3

58

Aansluitende functie

la

3,3

4,0

4,0

84

3,3

84

Nee

0

3,2

3,3

69

3,2

3,3

Bta

G

0,04

$0,24 * *$

71

0

0,03

$0,22^{* * *}$

$0,14^{* * *}$

G

$0,12^{\text {*** }}$

a = gecontroleerd woor de invloed wan opleidingssector, leeftijd, sekse, etriciteit, vooropleiding, betaald werk/stag ring, intredewerkloosheid, bedriffsgrootte en publieke sector

$*=$ significant op $5 \%$-niveau 
Tot slot zijn schoolverlaters met een niet-aansluitende functie minder tevreden dan schoolverlaters met een bij de behaalde kwalificaties aansluitende functie. Het gaat hierbij allereerst om de tevredenheid met de huidige functie. Schoolverlaters die niet werkzaam zijn in een functie waarvoor zij zijn opgeleid zijn - ongeacht onderwijssoor minder tevreden met de huidige functie dan degenen die werken in een bij de opleiding aansluitende functie. Het grootste verschil is aanwezig bij BBL niveau 3/4:0,7 punten. Bij BOL niveau $1 / 2$ en BOL niveau $3 / 4$ bedraagt het verschil 0,5 punten; bij BBL. niveau $1 / 20,4$ punten. Deze verschillen kunnen nauwelijks worden toegeschreven aan andere relevante verschillen tussen schoolverlaters: in het gecontroleerde geval blijven de verschillen bestaan. Hetzelfde geldt voor de èta's, die bijna ongewijzigd zijn gebleven na controle voor allerlei kenmerken van schoolverlaters. Daarnaast gaat het om de tevredenheid met de gevolgde opleiding. Voor alle onderwijssoorten geldt dat schoolverlaters die in een niet-aansluitende functie werken, achteraf bezien, minder vaak dezelfde opleiding opnieuw zouden kiezen dan schoolverlaters die in een aansluitende functie werkzaam zijn. Zo geeft bij BBL niveau $1 / 279 \%$ van de schoolverlaters die in een functie werken waarvoor ze zijn opgeleid aan dat zij opnieuw voor clezelfde opleiding zouden kiezen tegenover $53 \%$ van degenen die niet in een functie werkzaam zijn waarvoor ze zijn opgeleid. Dit verschil levert een èta op van 0,23 , die daalt naar 0,18 als rekening wordt gehouden met allerlei andere kenmerken van schoolverlaters. $\mathrm{Bij} \mathrm{BOL}$. niveau $1 / 2$ en BOL niveau $3 / 4$ zijn de verschillen in tevredenheid met de gevolgde opleicling wat groter; bij BBL niveau $3 / 4$ een stuk kleiner.

\subsection{Samenvatting}

In dit hoofdstuk is achtereenvolgens onderzocht in hoeverre de aansluiting tussen de behaalde kwalificaties en de gevonden functie verschilt tussen schoolverlaters van de $\mathrm{BOL}$ en de BBL, waarom een aantal van deze schoolverlaters niet werkzaam is in een aansluitende functie en of $\mathbf{z i j}$, indien mogelijk, eventueel wel in een functie willen werken waarvoor zij zijn opgeleid, en in welke mate het niet werkzaam zijn in een aansluitende functie gevolgen heeli voor de arbeidsmarkipositic van schoolverlaters. 1) empirische analyse die daartoe is verricht, heeft de volgende resultaten opgeleverd.

Naar voren is gekomen dat bijna eenvierde van de scluolverlaters van het secundlair beroepsonderwijs niet werkzaam is in een a ansluitende functie. Daarbij zijn BOL.ers en schoolverlaters met een opleiding op niveau $1 / 2$ vaker in een niet-aansluitende functix werkzaam dan BBLers en schoolverlaters met een opleiding op niveau 3/4. Verder werken schoolverlaters van de sectoren landbouw en economie relaticf vatak in een niedaansluitende functie. Voor een deel kunnen deze verschillen worden loegeschreven atan verschillen in anclere relevante kenmerken van schoolverlaters.

De belangrijkste reden dat een aantal schoolverlaters niel werkzatam is in een aansluitende functie is dat zij niet (meer) willen werken in de richting warvoor zc zijn opgeteid Dit geldt voor eenderde van de schoolverlaters met een niet-aansluitende functice. Vorder heeft ongeveer eenviffde geen werk kunnen vinden dat aansluit bij de helaakle kwaldhcaties. Ook een tegenvallend salaris, beperkte caurieremogelijkheden en werktijden dic: niet bevallen worden regelmatig als reden genoemd. voor de meeste reclenen geddl dal het alandeel schoolverlaters dat deze redenen noemt, witeenloopt natar onderwijsson on 
Desondanks is nog altijd $65 \%$ van de schoolverlaters met een niet-aansluitende fu bereid om te werken in een functie waarvoor ze feitellijk zijn opgeleid. Daarbij be verschillen tussen onderwijssoorten en opleidingssectoren. Zo willen schoolver van de BOL wat vaker eventueel wel werken in een functie waarvoor ze zijn opg dan schoolverlaters van de BBL. Ook willen schoolverlaters die een opleiding gevolgd in de sector landbouw of gedrag en maatschappij vaker eventueel wel wo in een functie die aansluit bij de behaalde kwalificaties. Voor een deel hangen deze schillen samen met andere relevante verschillen tussen schoolverlaters.

Het hebben van een functie die niet aansluit bij de behaalde kwalificaties heeft na ge gevolgen voor de arbeidsmarktpositie. Schoolverlaters met een niet-aansluit functie hebben minder vaak vast werk en verdienen een lager bruto uurloon schoolverlaters die in een aansluitende functie werkzaam zijn. Voor beide aspecter de arbeidsmarktpositie getdt overigens dat een aanzienlijk deel van deze verschill toe te schrijven an verschillen in andere kenmerken tussen schoolverlaters. Verc gebleken dat schoolverlaters die niet werkzaam zijn in een functie waarvoor zi opgeleid, minder positief oordelen over hun carrièremogelijkheden dan schoolverl die wel in een lunctie werken waarvoor zij zijn gekwalificeerd. Ook zijn schoolverl met een niet-aansluitende functie minder tevreden dan schoolverlaters met een b behaalde kwalificaties alansluitende functie. Het gaat hierbij zowel om de tevreden met de huidige functie alls die met de destijds gemaakte opleidingskeuze.

Tot slot is alangetoond dat de negatieve arbeidsmarkteffecten van een gebrekkige sluiting tussen de behalde kwalificaties en de gevonden functie niet sterker zijn schoolverlaters van de BBL dan voor de BOL. In een aantal gevallen blijkr juis omgekeerde te gelden, namelijk dat BOL'ers de vaardigheden die zij hebben aa leerd tijdens de opleiding buiten het eigen beroependomein minder productief kun aanwenden dan BBL'ers. 


\section{De waarde van een startkwalificatie: verschillen tussen jaren en sectoren}

\subsection{Inleiding}

Het Nederlandse onderwijsbeleid is erop gericht om jongeren minimaal een startkwalificatie te laten behalen, dat wil zeggen ten minste een diploma HAVO, VWO of een opleiding $\mathrm{BOL}, \mathrm{BBL}$ op niveau 2. Een startkwalificatie word gezien als het niveau dat minimaal noodzakelijk is om op een goede manier te kunnen functioneren op de zich snel veranderende arbeidsmarkt. Om de warde van een startkwalificatie te bepalen heeft het ROA recentelijk het extern rendement van opleidingen op niveau 2 onderzocht en deze vergeleken met het extern rendement van zowel de opleidingen die daar vlak boven zitten (de opleidingen op niveau 3 en 4) als de opleidingen die daar onder zitten (niveau 1 en VBO). De conclusie van deze analyse - gebaseerd op gegevens uit RUBS - is dat het gekozen niveau 2 als startkwalificatie redelijk adequat is (Van der Velden, De Vries, Wolbers \& Van Ejjs, 2003). Voor een groot aantal aspecten van hel extern rendement kan worden geconstateerd dat niveau 2 van de kwalificatiestructuur relatief goede opbrengsten genereert op de arbeidsmarkt. De varag is echter of de conclusie van dit onderzoek - gehouden in een periode van hoogconjunctuur - ook overeind blijft in tijden dat het minder goed gaat op de arbeidsmarkt. Om dit te onderzoeken wordt bovengenoemde analyse in dit hoofdstuk herhaald, maar nu vergeleken met een cohort van schoolverlaters dat in relatief slechtere omstandigheden de arbeidsmarkı heeft betreden. Bovendien wordt de eerdere analyse uitgebreid door verschillen tussen opleidingssectoren in beeld te brengen als het gaat om de warde van niveau 2 opleidingen.

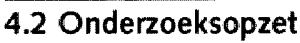

De relatie tussen het aantal jaren scholing en het bereikte competentieniveau of cle verwachte oplrengsten op de arbeidsmarkt kan continu of discontinu verlopen. Bij een continu verloop geld dat bij ieder additioneel jaar scholing de verwachte oplorengsten in gelijke mate toenemen. Bij een discontinu verloop kan het zijn dat vanal een bepaiald opleidingsniveau de verwerving van relevante competenties sterk intensiveert en dalldoor de opbrengsten sterk toenemen. Uitgaande van gelijke kosten voor elk jaar additionele scholing, kan in het laatste geval worden alangegeven wat de marginale verbetering bij éen jaar additionele scholing het grootst is. Met andere woorden: daar is de relatieve sprong het grootst Deze sprong kan worden gezien als cle overgang natar opleidingen die relatief goede ophrengsten opleveren op de arbeidlsmarkı.

De waarde van opleidingen voor schoolverlaters op de arbeidsmarkı word in dit hoofdstuk onderzocht aan de hand van een zestal indicatoren. Het betreft de kans op deelname aan vervolgonderwijs, de kans op betaald werk, de kans op een vaste laan, het niveau van het beroep, de kans op een baan in de eigen richting en het bruto uurloon. Deze indicatoren geven samen een goed beekd van de arbeidsmarktpositie van schoolverlaters. De schoolverlaters van de BOL en de BBL. worden aparl geanalyseerd. 
ters van beide leerwegen aanzienlijk van elkaar kunnen verschillen wat betreft $\mathrm{d}$ opbrengsten op de arbeidsmarkt (De Vries \& Wolbers, 2002). In de analyse wordt reke ning gehouden met individuele kenmerken van schoolverlaters (geslacht, leeftijd, etn citeit en de gevolgde opleidingssector). Daarnaast word - in tegenstelling tot $\mathrm{d}$ eerdere analyse die het ROA heeft uitgevoerd - ook rekening gehouden met het onder scheid tussen schoolverlaters die de opleiding in de oude en de nieuwe kwalificatie structur hebben gevolgd (pre-WEB versus WEB).

De opbouw van dit hoofdstuk is als volgt. Eerst wordt ingegaan op de vraag of ople dingen van niveau 2 relatief goede opbrengsten genereren op het moment dat $d$ omstandigheden op de arbeidsmarkt minder gunstig zijn. Hiertoe zijn schoolverlater van de meetjaren 1999 en 2000 , de meetjaren die in de eerdere analyse zijn gebruil (uitstroomcohorten 1997/1998 en 1998/1999), vergeleken met schoolverlaters van d meetjaren 2001 en 2002 (uitstroomcohorten 1999/2000 en 2000/2001). De resultate hiervan zijn weergegeven in de figuren 4.1. tot en met 4.6. Vervolgens worden verschi len tussen sectoren bestudeerd. Hiervoor worden de sectoren landbouw, techniek, ecc nomie en gezonclheidszorg vergeleken. De resultaten hiervan zijn vermeld in de figure 4.7 tot en met 4.12. Voor deze laatste analyse zijn schoolverlaters van de meetjaren 1999 2000, 2001 en 2002 samengenomen.

De cijfers in de hier gepresenteerde figuren geven de parameterschattingen weer voc de betreffende opleidingsniveaus waarbij het VBO als referentiecategorie dient. De ci fers in de figuren geven derhalve de afwijking ten opzichte van het VBO weer en kur nen worden geinterpreteerd als het effect van het volgen van een opleiding op nivea $1,2,3$ of 4 van de BOL of de BBL.

\subsection{Verschillen tussen jaren}

In deze paragraaf wordt de waarde van opleidingen voor schoolverlaters met relatio gunstige arbeidstmarktperspectieven (1990-2000) vergeleken met de waarde van ople dingen voor schoolverlaters met relatief minder gunstige arbeidsmarktperspectieve (2001-2002). Van helang dararbij is cle vraag in hoeverre de grens van wat wel of ni wordt gewatardeerd op de arbeidsmark verschuift op het moment dat de omstandighe den op cle arbeidsmatk veranderen. In de figuren 4.1 tot en met 4.6 is daarom vermel of cle verschillen in oplorengsten tussen de opeenvolgende opleidingsniveatus signif (ant afwijken. Dit is zowel voor cle meetjaren 1999-2000 als voor de meetjaren 200 2002 gedaan. Op deze manier kan worden alangegeven of een toename van éen nivea (d.w.z. eén jalar additionele scholing) voor schoolverlaters in 1999-2000 en/of in 200 2002 significant meer of minder oplevert op de arbeidsmarkt.

In liguur 1.1 is de kans op deelname an vervolgonderwijs weergegeven. Uit dez liguur blijkt voor de $30 \mathrm{O}$ dat de jaren 1999-2000 en 2001 -2002 een vergelijkbaar patroo volgen. Voor zowel 1999-2000 als 2001-2002 geldt dat bij de overgang van het VBO naa niveau I de grootste sprong wordt gemaakt. Hierbij geldt dat schoolverlaters van h VBBO valier deelnemen alan vervolgonderwijs dan schoolverlaters van niveau 1 . Verd laal deze figuur zien dat schoolverlaters van niveau 2 en niveau 3 relatief vaker kieze vor een vervolgopleiding dan schoolverlaters van niveau 1 , mar minder vaak da 
Ook bij de $\mathrm{BBL}$ wordt de grootste sprong in de deelname aan vervolgonderwijs gemaakt bij de overgang van het VBO naar niveau 1, waarbij geldt dat schoolverlaters van niveau 1 minder vaak kiezen voor een vervolgopleiding dan schoolverlaters van het VBO. Er bestaan hier echter verschillen tussen 1999-2000 en 2001-2002. Het verschil in deelname aan vervolgonderwijs tussen het VBO en BBL niveau 1 is in 2001-2002 kleiner dan in 1999-2000.

Figuur 4.1

\section{Deelname aan vervolgonderwijs naar jaar}

BOA

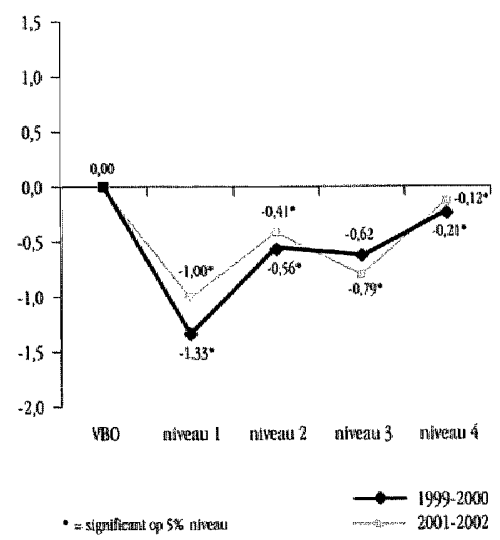

EB:

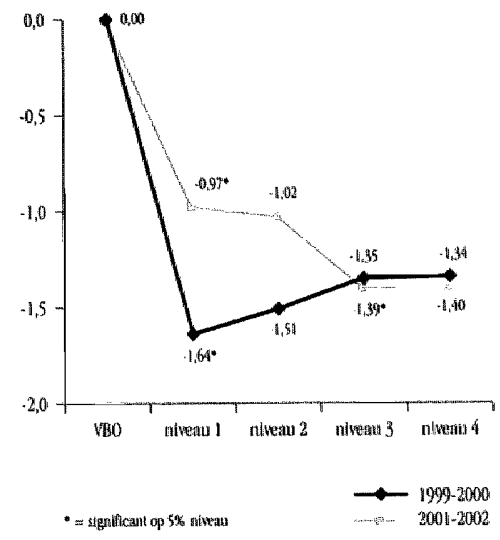

Figuur 4.2 laat de kans op werk zien voor schoolverlaters. Opvallend voor de BOL is dat in 2001-2002 schoolverlaters van BOL niveau 1 significant minder vaak betaald werk hebben dan schoolverlaters van het VBO. Daarnaast blijkt dat de kans op werk voor schoolverlaters van het VBO gelijk is aan die van schoolverlaters van BOL niveau 2. Pas bij de overgang van niveau 2 naar niveau 3 wordt in 2001-2002 een grote sprong gemaakt in de kans op werk. Aangezien voor 1999-2000 de grootste sprong in de kans op werk plaatsvindt bij de overgang van VBO naar niveau 1 verschuift bij de BOL de grens van opleidingen die een relatief goede kans bieden op werk van niveau 1 in 1999. 2000 naar niveau 3 in 2001-2002.

Ook voor de BBL geldt dat de grens van opleidingen die een relatief goede kans bicden op werk de afgelopen jaren is verschoven. In 1999-2000 doet de grootste sprong in de kans op werk zich voor bij de overgang van VBO naar niveau 1. Dit geldt nict in 2001-2002. De grootste verbetering vind hier plats bij de overgang van niveau I naar niveau 2. 

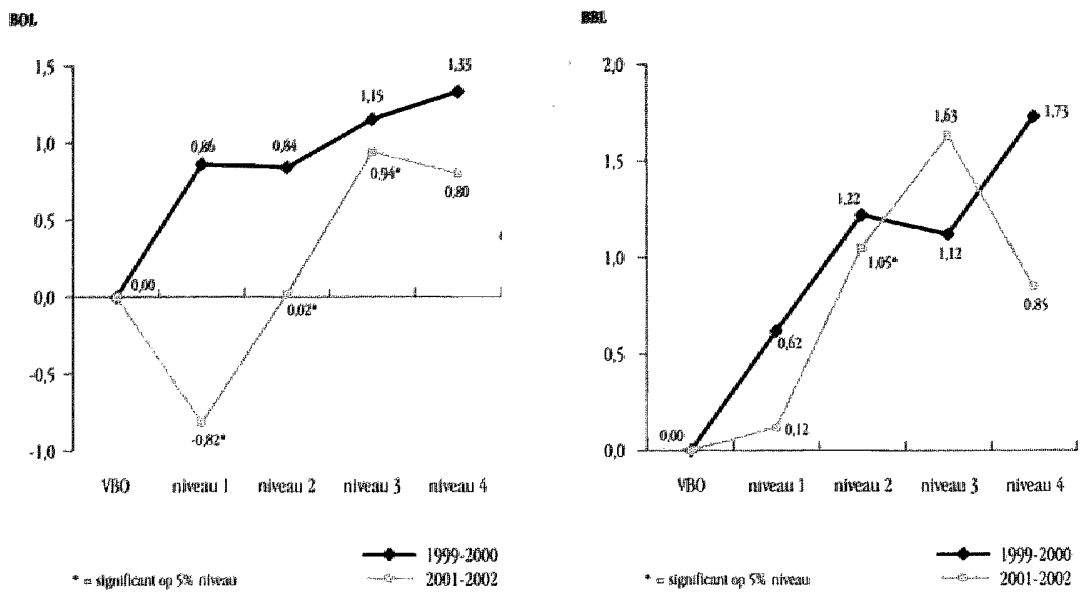

In figuur 4.3 is dle kans op een vast dienstverband vermeld. Voor de BOL geldt dat 2001-2002 de kans op een vast dienstverband voor schoolverlaters van niveau $\mathbb{1}$ ie kleiner is dan voor schoolverlaters van het VBO. In 2001-2002 ligt de grootste verbet ring van de kans op een vast dienstverband bij de overgang van niveau 2 naar nivea 3. Dit geldt overigens ook voor 1999-2000. Daarmee lijken opleidingen van niveau van de BOL wat betreft de kans op een vast dienstverband eerder op opleidingen va niveau 1 en het VBO dan op opleidingen van niveau 3 of 4 .

Voor de BBL geldt dat de kans op een vast dienstverband in 1999-2000 de groots sprong vooruit maakt bij cle overgang van VBO naar niveau 1. In 2001-2002 is de kat op een vast dienstverlband datarentegen vrijwel gelijk voor schoolverlaters van het VB en BIBL niveau 1. De grote sprong in de kans op een vaste aanstelling wordt in 200 2002 gemaak bij de overgang van niveau 2 naar niveau 3.

In figuur 4.4 is het nivealu van de batan van schoolverlaters weergegeven. Uit deze figu komt natar voren dat er bij de BOL. vrijwel geen verschillen bestaan tussen 1999-2000 2001-2002. De grote verbetering in hel niveau van hel beroep doet zich voor bij de ove gang van nivea I nalar niveau 2. Daarmee verschillen schoolverlaters van BOL nive: 2 duidelijk van schoolverlaters van BOL niveau $\mathbb{I}$ en het VBO.

Bij de BBBL bestatun tussen de jaren met name verschillen bij niveau 1. Voor 1999-200 geldt dat schoolverlaters van niveau 1 een baan hebben gevonden van een hog niveatu dan schoolverlaters van het VBO. In 2001-2002 is het niveau van de baan va schoolverlaters van nivealu $\mathbb{\downarrow}$ iets lager. De grootste verbetering in het niveau van baan doet zich bij de BBL, overigens voor bij de overgang van niveau 2 nalr niveau Dit gekde zowel voor 1990-2000 als voor $2001-2002$. 
Figuur 4.3

Kans op een vast dienstverband naar jaar
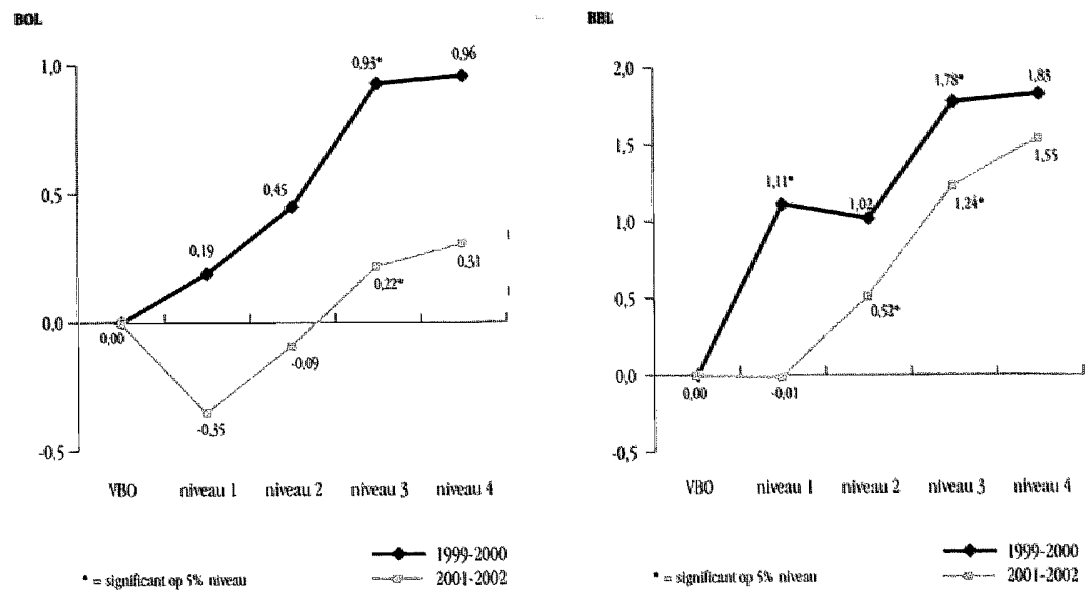

Figuur 4.4

Niveau van het beroep naar jaar

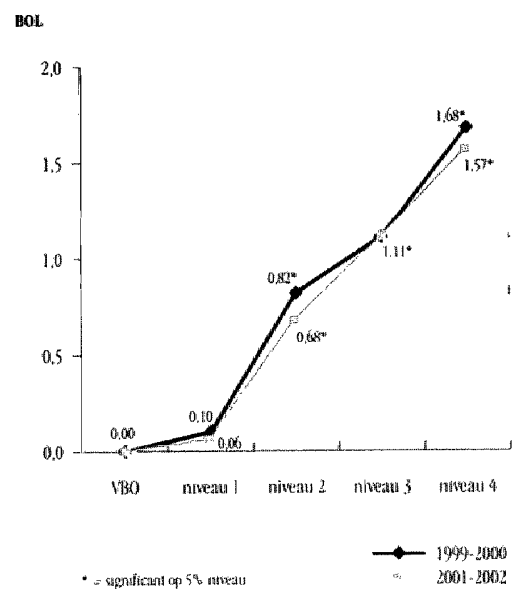

BD:

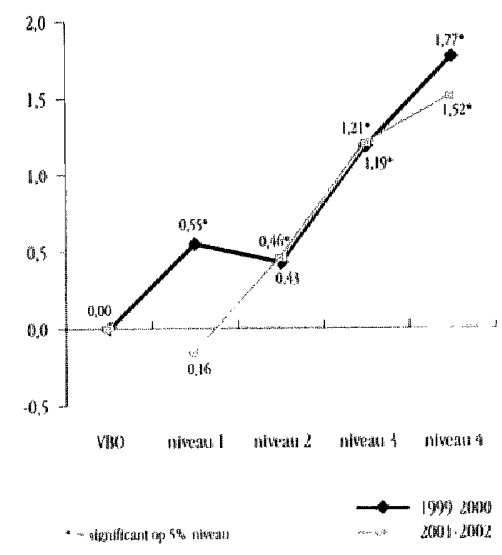

In figuur 4.5 wordt ingegaan op cle vraag of schoolverlaters een baan hebben gevonden die aansluit bij de gevolgde opleidingsrichting. Bij de BOL wordt in 1999-2000 cle grootste verbetering in de kans op een baan in de eigen richting gemaakt bij de overgang van niveau 2 nar niveau 3. Voor 2001-2002 geldt dat de grootste verbetering in de kans op een baan in de eigen richting plaatsvindt bij de overgang van niveau 1 naar niveau 2. Dit is opvallend. omdat hier de grens terugschuift van niveau 3 in $1999-2000$ natr niveau 
Hit.

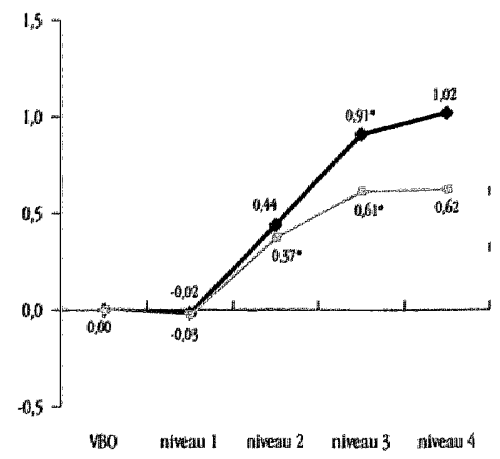

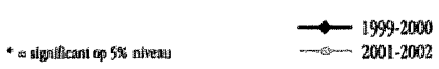

as

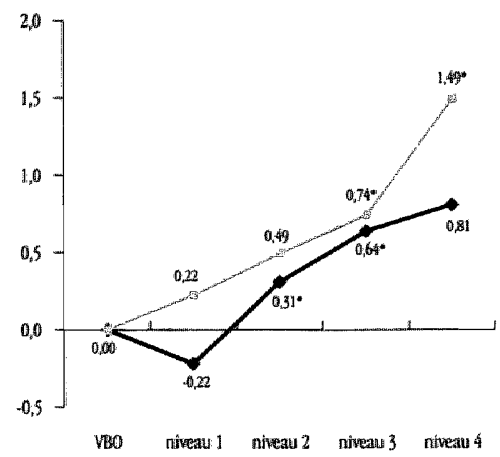

$\longrightarrow-1999-2000$

Figuur 4.6

Bruto uurloon naar jaar

1อบ

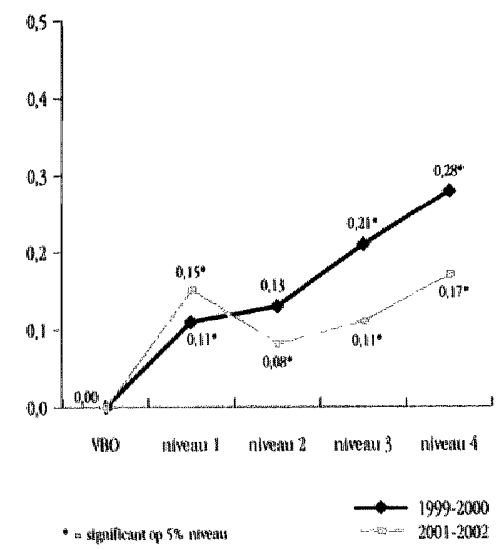

BBL.

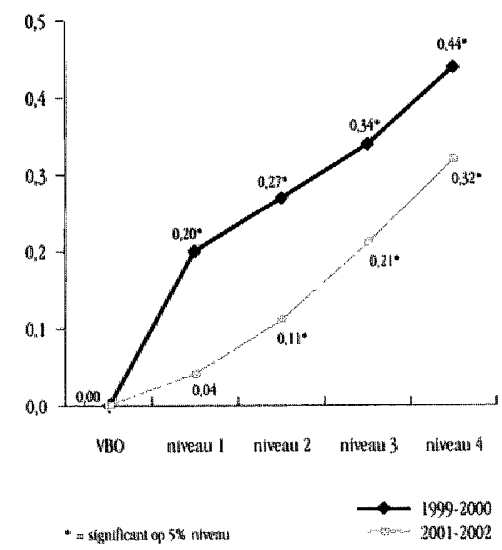

Bij de BBL doet in 1999-2000 de grootste verbetering in de kans op een baan in de eige richting zich voor bij cle overgang van niveau 1 naar niveau 2 . Wat dit betreft verschi 1999-2000 van 2001-2002. In 2001-2002 neemt de kans op een baan die aansluit bij d gevolgde opleidingsrichting voor BBL-ers vrij geleidelijk toe per niveau, waarbij d overgang van niveau 3 naar niveau 4 cle grootste verbetering in deze kans laat zien.

Tor slot van deze paragraaf wordt ingegaan op de beloning van schoolverlaters. I 
naar niveau 1 een grote verbetering in het bruto uurloon van schoolverlaters oplevert. Zowel in 1999-2000 als in 2001-2002 wordt hier de grootste sprong gemaakt.

Bij de BBL vindt in 1999-2000 de grootste verbetering in het bruto uurloon plaats bij de overgang van het VBO naar niveau 1. In 2001-2002 neemt het bruto uurloon van schoolverlaters per opleidingsniveau vrij geleiclelijk toe. De grootste sprong vindt hier plaats van niveau 3 naar niveau 4. Kortom, bij de BBL verschuift de grens van opleidingen die een relatief goede beloning opleveren van niveau 1 in 1999-2000 naar niveau 4 in 20012002.

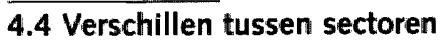

In deze paragraaf wordt het extern rendement van opleidingen per sector met elkaar vergeleken. De resultaten van deze analyse zijn weergegeven in de figuren 4.7 tot en met 4.12. ${ }^{20}$ Ook hier wordt bekeken waar de grens ligt van wat wel of niet wordt gewaardeerd op de arbeidsmarkt. In de figuren is voor elke sector vermeld of de verschillen in opbrengsten tussen de opeenvolgende opleidingsniveaus significant van elkaar afwijken. Dit houdt in dat er wordt onderzocht of een toename van één niveau voor schoolverlaters in een bepaalde sector meer of minder oplevert op de arbeidsmarkt.

In figuur 4.7 wordt ingegaan op de deelname aan vervolgonderwijs. Voor de BOL geld dat schoolverlaters van de sector techniek van niveau 1 en niveau 2 bijna even vaak doorstromen naar het vervolgonderwijs als schoolverlaters van VBO techniek. Ook voor de sector gezondheidszorg geldt dat schoolverlaters van niveau 2 weinig verschillen van schoolverlaters van VBO gezondheidszorg. Bij de sectoren techniek en gezondheidszorg daalt de deelname aan vervolgonderwijs pas aanzienlijk bij de overgang van niveau 2 naar niveau 3 . Voor de sector economie geldt daarentegen dat schoolverlaters van niveau 1 veel minder vaak dan schoolverlaters van VBO economie verder gaan leren. Daarnaast geldt bij landbouw dat schoolverlaters van niveau 2 minder vaak cleelnemen aan vervolgonderwijs dan schoolverlaters van V13O landbouw.

Bij de sectoren techniek en economie van de BBL nemen schoolverlaters van niveau 1 minder vaak deel aan vervolgonderwijs dan schoolverlaters van het VBO van deze sectoren. Overigens is de daling van de deelname in het vervolgonderwijs bij cle overgang van VBO naar niveau 1 groter voor de sector economie dan voor de sector technick. verder geldt voor de sectoren landbouw en gezondheidszorg dat schoolverlaters van niveau 2 duidelijk minder valk deelnemen aan vervolgonderwijs dan schoolverlalers van deze sectoren in het VBO.

20 In de figuren ontbreken cijfers voor $\mathrm{BOL}$ niveau 1 landbouw, BOL. niveau 1 gexondhelelszotg, 1513L. niveau 1 landbouw en BOL niveau $\mathbb{1}$ gezondheidszorg en de ciffers van de sector gedrag en matlschappij. Opleidingen van niveau 1 worden in de sector landbouw nies angeboden en opplejdingen van niveau I van de sector gezondheidszorg zijin niel in de geanalyseerde data aanwezig. I se sector gedrag en maatschappij is niet meegenomen in de analyse. comdal deze sector niet bestat in het 
Figuur 4.7

Deelname aan vervolgonderwijs naar sector
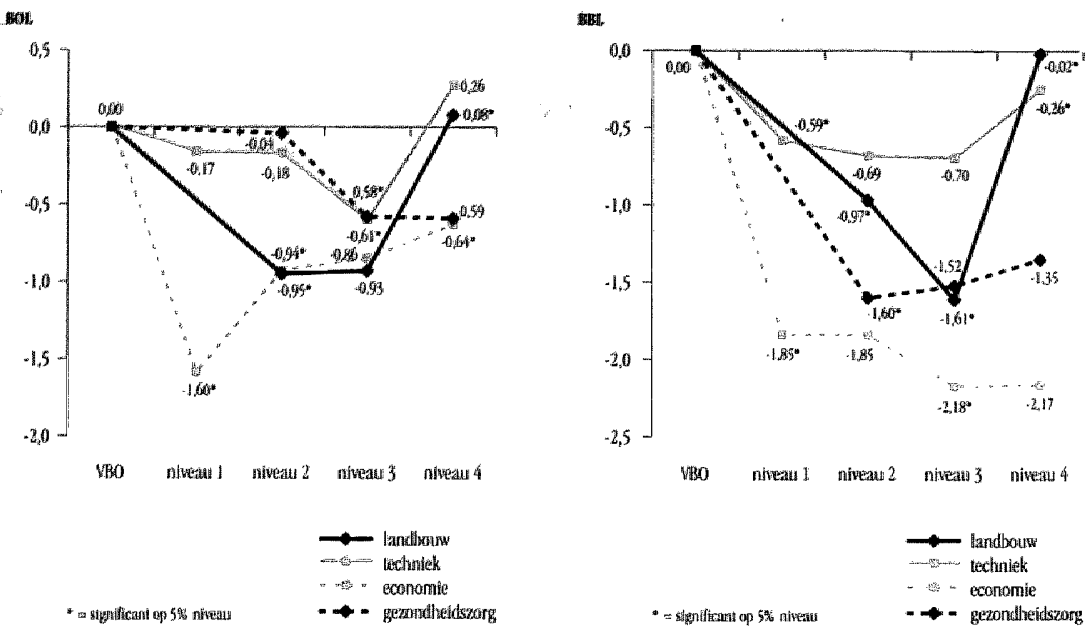

Tabel 4.8 laat de kans op werk zien voor verschillende sectoren. Bij de sector technieh wordt bij de overgang van niveau 1 naar niveau 2 de grootste sprong in de kans op wert gemaakt. Dit geldt niet voor de sector economie. In deze sector doet de grootste sprong in de kans op werk zich voor bij de overgang van niveau 2 naar niveau 3 . Ook bij $\mathrm{d}$ sectoren gezondheidszorg en landbouw doet de grootste verbetering in de kans of werk zich voor bij de overgang van niveau 2 naar niveau 3 .

Fighuur 4.8

Kans op werk naar sector

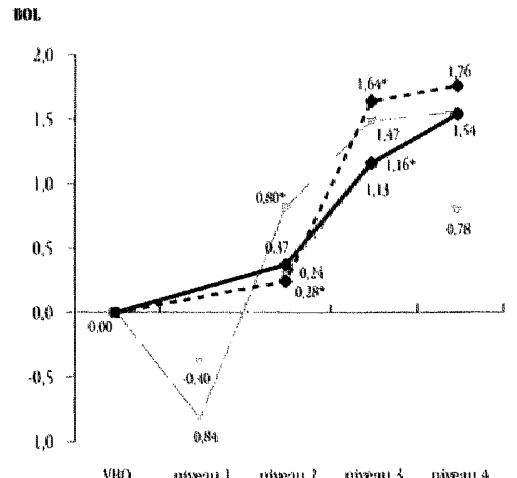

nat.

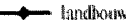

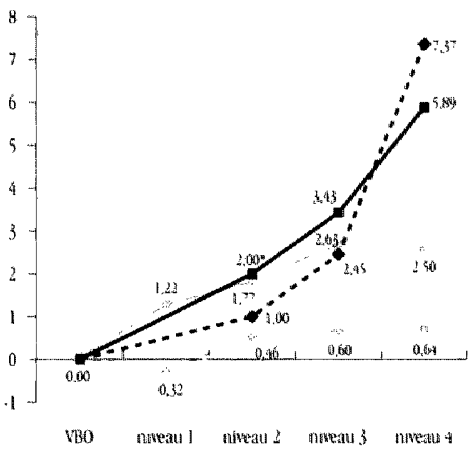

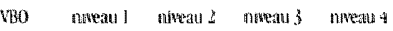


Bij de BBL neemt bij de sector techniek de kans op werk aanzienlijk toe bij de overgang van het VBO naar niveau 1 . Bij de sector economie doel de grootste sprong in de kans op werk zich voor bij de overgang van niveau 1 naar niveau 2 . Voor de sectoren landbouw en gezondheidszorg geldt dat de grootste verbetering van de kans op werk plaatsvindt bij de overgang van niveau 3 naar niveau 4 .

Uit figuur 4.9 blijkt dat bij de sector techniek de kans op een vast dienstverband voor schoolverlaters van niveau $1 \mathrm{kleiner}$ is dan voor schoolverlaters van het VBO. De kans op een vaste aanstelling neemt in de sector techniek behoorlijk toe bij de overgang van niveau 1 naar niveau 2. Ook voor de sector landbouw geldt dat schoolverlaters van niveau 2 vaker dan schoolverlaters van VBO landbouw een vaste aanstelling hebben. Voor de sectoren economie en gezondheidszorg geldt dat de grootste verbetering in de kans op een vaste aanstelling plaatsvindt bij de overgang van niveau 2 naar niveau 3.

Bij de sector economie van de BBL ligı de grens van opleidingen die een relatiel goede kans bieden op een vast dienstverband bij de overgang van het VBO naar niveau 1. Voor schoolverlaters van de sector landbouw geldt dat schoolverlaters van niveau 2 een relatief grotere kans hebben op een vast dienstverband dan schoolverlaters van VBO landbouw. Bij de sector techniek vindt de grootste verbetering in de kans op een vast dienstverband plaats bij de overgang van niveau 2 naar niveau 3 . Voor de sector gezondheidszorg is dit bij de overgang van niveau 3 naar niveau 4 .

Figurur 4.9

Kans op een vast dienstverband naar sector
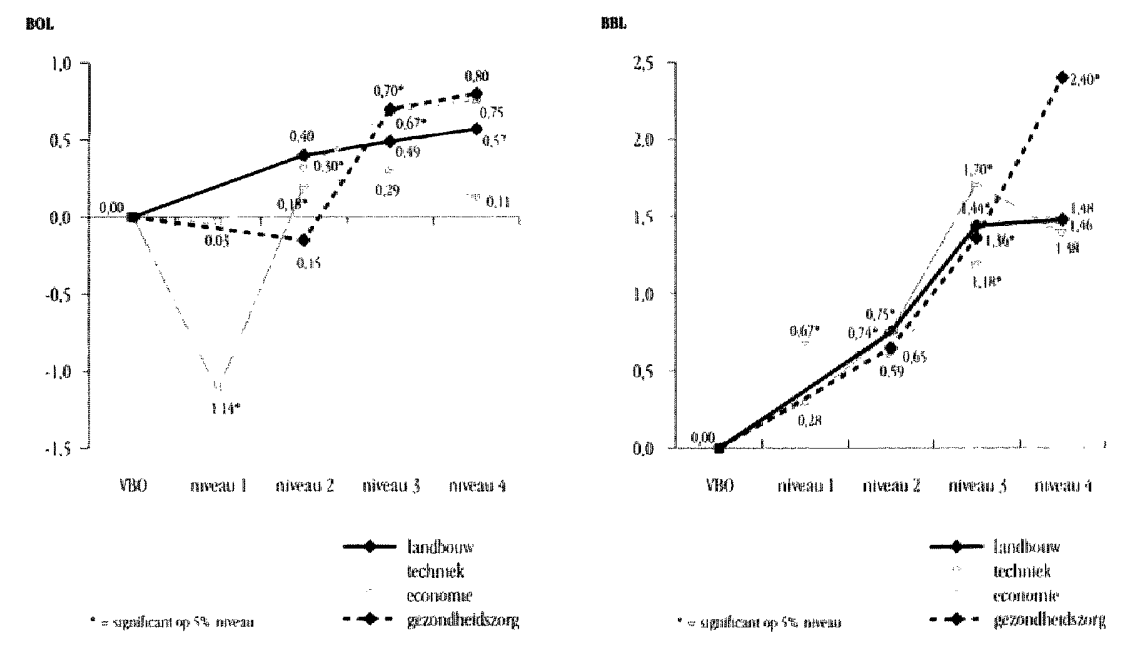

In liguur 4.10 is het niveau van het beroep weergegeven. Uil deze figuur blijkı voor de BOL dat bij de sectoren techniek en economie het niveau van het beroep van schoolverlaters van thet $V B O$ en niveau 1 niet significant van elkaar verschillen. Do ovcrgang 
Piguur 4.10

Niveau van het beroep naar sector
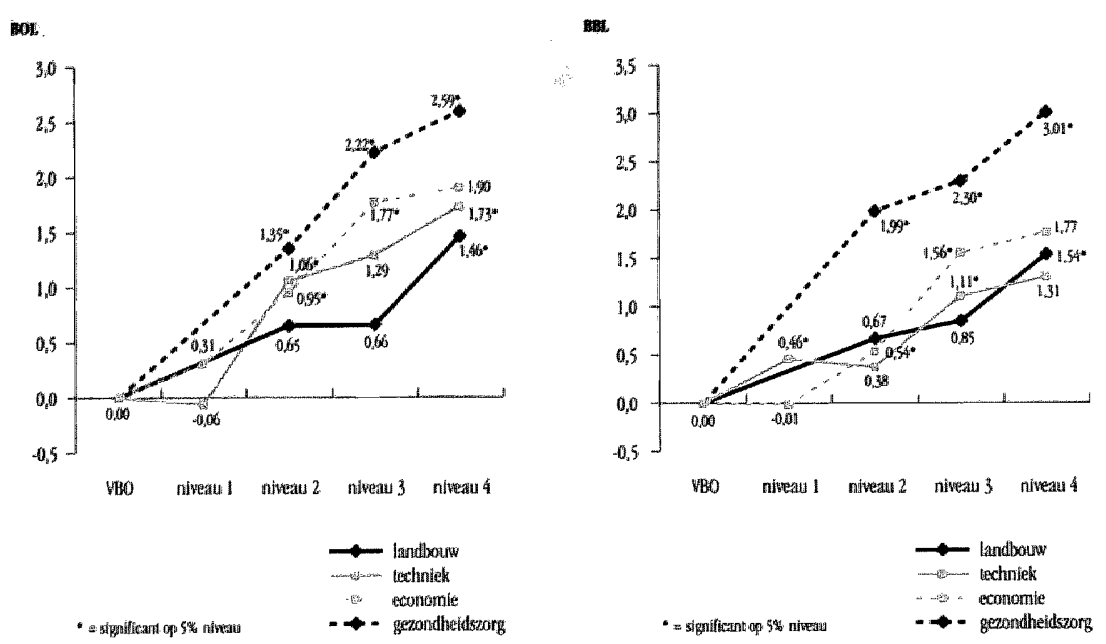

ging zien van het niveau van de baan. Voor de sector economie geldt dat de grootste sprong in het niveau van het beroep zich voordoet bij de overgang van niveau 2 naa niveau 3. Daarnaast komt naar voren dat bij de sector gezondheidszorg het niveau var de baan van schoolverlaters van niveau 2 aanzienlijk hoger is dan voor schoolverlater van VBO gezondheidszorg. Voor de sector landbouw geldt daarentegen dat bij de over gang van niveau 3 naar niveau 4 de grootste sprong in het niveau van de baan plaats vindt.

Verder komt naar voren dat bij de BBL de grote sprong in het niveau van het beroep bi de sectoren techniek en economie word gemaakt bij de overgang van niveau 2 naa niveau 3. Voor de sector gezondheidszorg geldt dat het niveau van de baan van school verlaters van niveau 2 significant hoger is dan voor schoolverlaters van VBO gezond heidszorg. Bij de sector landbouw ligt de grens van opleidingen die een relatief goed baan qua niveau opleveren bij de overgang van niveau 3 nat niveau 4 .

Figuur 4. I I laa vervolgens de kans op een baan in de eigen richting zien. Voor de sec toren techniek en economie geldt dat schoolverlaters van BOL niveau 1 niet beter 'sco ren' dan schoolverlaters van deze sectoren van het VBO. Vervolgens laat de secto economie een relatief grote verbetering zien in de kans op een baan in de eigen rich ting bij de overgang van niveau 1 naar niveau 2. Dit geldt niet voor de sector techniek watar de grootste sprong zich voordoet bij de overgang van niveau 2 naar niveau 3 . Voo de sectoren landbouw en gezondheidszorg geldt dat bij niveau 2 het verschil met he VIBO in de kans op een baan die qua richting aansluit bij de gevolgde opleiding relatie groot is. Voor beide sectoren geldt dat hier de grootste sprong plaatsvindt. 
Vervolgens laat de sector techniek bij de overgang van niveau 1 naar niveau 2 een relatief grote stijging zien. Verder blijkt dat schoolverlaters van niveau 2 van de sector gezondheidszorg relatief vaker een baan hebben gevonden die qua richting aansluit bij de gevolgde opleiding dan schoolverlaters van VBO gezondheidszorg. Voor de sector economie geldt daarentegen dat de kans op een baan in de eigen richting voor schoolverlaters van niveau 2 niet verschilt van die van het VBO. Bij de sector economie doet de grootste verbetering in de kans op een baan in cle eigen richting zich voor bij de overgang van niveau 2 naar niveau 3. Dit geldt ook voor de sector landbouw.

Figuur 4.11

Kans op een baan in de eigen/verwante richting maar sector
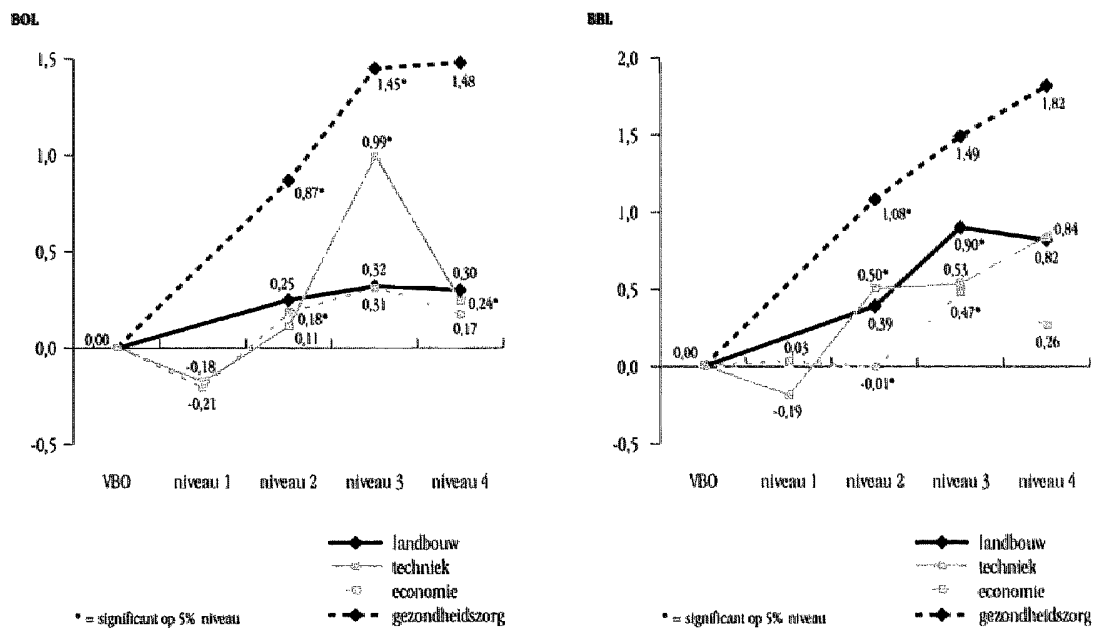

Tot slot is in figuur 4.12 het bruto uurloon per sector vermeld. Voor de sectoren techniek en economie geldt dat schoolverlaters van niveau 1 een significant hoger bruto uurloon hebben dan schoolverlaters van het VBO. Ook voor de sector gezondheidszorg geldt dat de overgang van VBO naar niveau 2 de grootste verbetering laat zien in het bruto uurloon. Voor schoolverlaters van de sector landbouw van niveau 2 geld dalarentegen dat het bruto uurloon gelijk is an die van het VBO. Bij deze sector doel de grootste sprong in bruto uurloon zich voor bij de overgang van niveau 3 naar niveau 4.

Opvallend voor de BBL is dat het bruto uurloon bij de sectoren geleidelijk toeneemt met de stijging van het opleidingsniveau. Daarbij geldt voor de sectoren techniek en economie dat de grootste toename in bruto uurloon plaatsvindt bij de overgang van het VBO naar niveau 1. Daarnaast doet bij de sectoren landbouw en gezondheidszorg de grootste verbetering in bruto uurloon zich voor bij de overgang van het VBO naar niveau 2. 
Figuur 4.12

Bruto uurloon naar sector
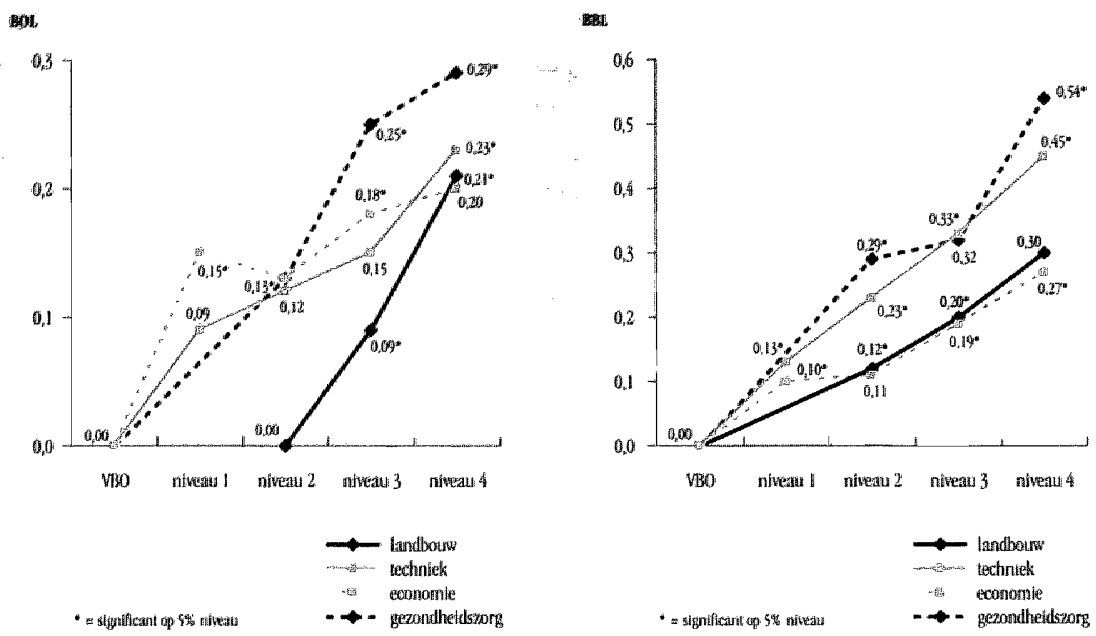

\subsection{Samenvatting}

Recentelijk is het extern rendement van opleidingen op niveau 2 onderzocht en is dez vergeleken met het extern rendement van zowel de opleidingen die daar vlak bove zitten (de opleidingen op niveau 3 en 4) als cle opleidingen die daar onder zitte (niveau 1 en VBO). De conclusie van deze analyse is dat het gekozen niveau 2 als star kwalificatie redelijk adequat is. In dit hoofdstuk is onderzocht of de conclusie van d onderzoek - clat is gehouden in een periode van hoogconjunctuur - ook overeind blij in tijden dat het minder goed gaat op de arbeidsmarkt. Hiertoe is bovengenoemde an: lyse heshald, mar nu vergeleken met een cohort van schoolverlaters dat in relatio slechtere omstandigheden de arbeidsmarkı heeft betreden. Bovendien is het extern rer dement van niveau 2 opleidingen voor verschillende opleidingssectoren vergeleken.

De tabellen 4.1 en 4.2 geven een overzicht van de belangrijkste resultaten van de ver gelijking tussen jaren. In deze tabellen is voor de BOL en de BBL aangegeven tusse welke opleidingsniveaus zich de yrootste relatieve verbetering voordoet in termen va oplorengsten op de arbeidsmarkt. Daarbij is aangegeven of het verschil significant is tus sen de opeenvolgende niveaus. Tabel 4.1 taat zien clat bij de BOL in 1999-2000 de gren van opleiclingen die een relatief grote verbetering opleveren in opbrengsten drie ma: ligt tussen het $\mathrm{V} B \mathrm{BO}$ en $\mathrm{BOL}$, niveau 1 (deelname aan vervolgonderwijs, kans op werk e bruto uurloon) één maal ligt tussen $B O L$ niveatu 1 en $B O L$ niveau 2 (niveau van he beroep) en twee maal ligt tussen BOL niveau 2 en $B O L$ niveau 3 (kans op een va: dienstverband en kans op een baan in de eigen richting). Alleen voor de kans op wer gelde dat het verschil tussen het VBO en BOL niveau I niet significant is. In 2001-200 kan bij de BOL de grens van opleidingen die een relatief grote verbetering oplevere 
derwijs en bruto uurloon), twee maal tussen BOL niveau 1 en BOL niveau 2 (niveau van het beroep en kans op een baan in de eigen richting) en rwee maal tussen BOL niveau 2 en BOL niveau 3 (kans op werk en kans op een vaste dienstverband).

Tabel 4.1

Bepaling van de grens van opleidingen van de BOL die een relatief goede start bieden op de arbeidsmarkt, voor verschillende jaren

BOL

Deelname aan vervolgonderwijs

Kans op werk

Kans op een vast dienswerband

Niveau van het beroep

Kans op een baan in de eigen richting

Bruto uurloon
$1999-2000$

VBO - niveau $\mathbb{I}^{*}$

VBO - niveau $\mathbb{1}$

niveru 2 - niveau $3^{*}$

nivean 1 - niveau $2^{*}$

nivean 2 - niveau 3 *

VBO - niveau : $^{\text {* }}$

\section{1-2002}

$\mathrm{BBO}-$ niveau $]^{*}$ niveau 2 - nivenu $3^{\text {* }}$ niverm 2 - niveau $3^{\text {* }}$ niveau 1 - niveau $2^{\text {* }}$ niveau 1 - niveau $2^{\text {ts }}$ VBO - niveau $1^{*}$

* = significant verschil tussen opeenvolgende niveaus op $5 \%$-niveau

Uit tabel 4.2 komt naar voren dat bij de BBL de grootste verbetering zich in 1999-2000 vier maal voordoet bij de overgang van het VBO naar BBL niveau 1 , eén maal bij de overgang van BBL niveau 1 naar BBL niveau 2 en éen maal bij de overgang van BBB. niveau 2 naar BBL niveau 3. Voor 2001-2002 geldt dat de belangrijkste sprongen zich één maal voordoen bij de overgang van het VBO naar BBL niveau 1, éen maal bij de overgang van BBL niveau 1 nar BBL niveau 2, twee maal bij de overgang van BBBL. niveau 2 naar BBL niveau 3 en twee maal bij de overgang van BBL niveau 3 naar BBLL niveau 4 .

Tabel 4.2

Bepaling van de grens van opleidingen van de BBL die een relatief goede start bieden op de arbeidsmarkt, voor verschillende jaren

BBL

Deelname aan vervolgonderwijs

Kans op werk

Kans op een vast dienstverband

Niveat van het beroep

Kans op exn baan in de eigen richling

Bruto uurloon
1999-2000

VBO - nivean ! 'to

VBO - niveau $]$

VBO - nivean $1^{\text {th }}$

niveau 2 - niveru $3^{\text {ta }}$

niveau 1 - niveau $2^{\text {m }}$

130 - niveau ! th
2001-2002

VBO - niveatu $1^{\text {th }}$ niveau 1 - nivean $2^{\text {ts }}$ niveau 2 - nivean $3^{\text {sh }}$ niveau 2 - niven $3^{\text {th }}$ niveau 3 - niveatu $4^{\text {th }}$ niveas $3-\operatorname{nives} 4^{\text {th }}$

* = significant verschil lussen opeenvolgende niveaus op $5^{\%}$-niveau

Wat hetekenen de\%e resultaten voor de warde van een starkwalificatic" Wannedr als uitgangspunt wordt genomen dal een startkwalificatice op exen zo grosel atantal indicaloren een relatieve verbetering moet opleveren ten opzichte van de lagere niveaus, dan roldoen in 1999-2000 opleidingen van BOL niveat 2 als startkwalificatic In 1999-2004 leveren opleidingen van BOL. niveau 2 bij vier van de zes indicatoren cen redatiel greste verbetering op in oplorengsten ten opzichte van de lagere opleidingsnivealus voror 
verbetering opleveren ten opzichte van het VBO. Hetzelfde geldt voor 2001-2002. in 2001-2002 geldt dat opleidingen van BOL niveau 2 bij vier van de zes indicatoren relatief grote verbetering in opbrengsten genereren ten opzichte van de lagere op dingsniveaus. Voor de BOL geldt daarom dat ook in 2001-2002 opleidingen van B niveau 2 redelijk voldoen als startkwalificatie voor schoolverlaters. Geconcludeerd worden dat opleidingen van BOL niveau 2 zich blijven onderscheiden van opleiding van lagere niveaus als de arbeidsmarktomstandigheden minder gunstig zijn.

Bij de BBL leveren opleidingen van niveau 2 in 1999-2000 bij vijf van de zes indica ren een relatief grote verbetering op in opbrengsten ten opzichte van de lagere op dingsniveaus. In 2001-2002 geldi dit maar voor twee van de zes indicatoren (deelna aan vervolgonderwijs en kans op werk). Voor de BBL kan dus worden geconclude dat de grens van opleidingen die een relatieve goede start bieden op de arbeidsma minder vast ligt dan voor de BOL. Deze grens verschuift tijdens een periode van eco mische neergang naar opleidingen met een hoger niveau.

In de tabetlen 4.3 en 4.4 zijn de belangrijkste resultaten van de vergelijking tussen s toren weergegeven. Wanneer per sector wordt bekeken tussen welke opleidin niveaus zich de grootste relatieve verbetering in opbrengsten voordoet, dan geldt v de sector techniek dat opleidingen van BOL niveau 2 bij vier van de zes indicatoren relatief grote verbetering opleveren ten opzichte van de lagere niveaus van deze sec Daarmee voldoen opleidingen van BOL niveau 2 van de sector techniek redelijk startkwalificatie. Dit geldt in jets mindere mate voor de sectoren landbouw, econor en gezondheidszorg van BOL niveau 2. Voor deze sectoren geld dat opleidingen BOL niveau 2 bij drie van de zes indicatoren relatief goede opbrengsten opleveren opzichte van de lagere niveaus.

Tabel 4.3

Bepaling van de grens van opleidingen van de BOL die een relatief goede start bieden op de arbeidsmarkt, per sector* *

BOL

Deelmane atan verwolgonderwis.s

Katns op wetk

kians op een vast dhenstrerband

Nwean wan het beroep

Kins op een baan in do eigen richtimg

Bruto uurloon

\section{Landbouw}

VBO-niveal 2 *

niveat 2 -niveau $3^{\text {t }}$

VB0-nivea 2

nivean 3 -nivean $4^{*}$

VBO-niveau 2

niveau 3-nivean $4^{\text {*t }}$
Techniek

n|veru 2-niveau $3^{*}$

niveau 1-niveau $2^{*}$

niveau I-niveau $2^{*}$

niveau 1 -nivean $2^{*}$

nivea 2-niveau $3^{\circ}$

VBO-niveau 1

\section{Economie}

VBO-niveau 1"

niveau 2 -niveau 3

nivenu 2 -nivera $3^{\text {s }}$

niveau 2-niveau $3^{\text {* }}$

nivenu 1-niveau $2^{\text {t }}$

VBO-riveau l*

\section{Gezondheidsz}

niveau 2-niveau

niveau 2-niveau

niveau 2-niveau

VBO-niveru 2*

VBO-nivenu 2*

VBO-niveau 2* 
Uit tabel 4.4 blijkt dat opleidingen van BBL niveau 2 van de sectoren techniek, economie en gezondheidszorg bij vier van de zes indicatoren een substantiële verbetering van de opbrengsten opleveren ten opzichte van de lagere niveaus van deze sectoren. Voor deze sectoren zijn opleidingen van BBL niveau 2 als startkwalificatie redelijk adequaat. Voor de sector landbouw geldt dat opleidingen van BBL niveau 2 bij drie van de zes indicatoren een relatieve verbetering opleveren ten opzichte van de lagere niveaus in deze sector. Daarmee voldoen opleidingen van BBL niveau 2 van de sector landbouw in wat mindere mate als startkwalificatie dan opleidingen van BBL niveau 2 van andere sectoren.

Tabel 4.4

Bepaling van de grens van opleidingen van de BBL die een relatief goede start bieden op de arbeidsmarkt, per sector* *

BBL

Deelname aan

vervolgonderwijs

Kans op werk

Kans op een vast dienstverband

Niveau van het beroep

Kans op een baan

in de eigen richting

Bruto uurloon
Landbouw

VBO-niveau $2^{\text {* }}$

nivean 3 -nivean 4

VBO-niveau $2^{\text {s }}$

niveru 3 -niveau $4^{40}$

niveau 2-njweau $3^{\text {* }}$

VBO-niveau 2*
Techniek

VBO-niveau 1 *

VBO-niveau 1

niveau 2 -niveau $3^{\text {m }}$

niveau 2-niveau $3^{*}$

niveau 1-niveau $2^{*}$

VBO-niveau |*

\section{Economie}

VBO-niveau 1\%

niveau 1-niveau 2

VBO-niveau $1^{\text {2* }}$

niveau 2-niveau $3^{\text {H }}$

VBO-niveau 2"

* = significant verschi] tussen opeenvolgende nivealus op $5 \%$-nivealu

* = voor de sectoren landbouw en gezondheidszorg ontbetken ciffers over niveau 1

VBO-niveau $\mathrm{I}^{\text {*3 }}$

W30-niveat $2^{\text {20 }}$

\section{Gezondheldszorg}

WBo-niveau 2*

niveau 3-niveat 4

niveat 3 -niveat $4^{\text {to }}$

Tot nu toe is bij de bepaling van een startkwalificalie alleen rekening geluoucken med het bereikte opleidingsnivean van schoolverlaters. Het voorgatande toont at dal sectoren enigszins van elkaar verschillen wat betreft de grens van opleidingen die cen relatice goede start bieden op de arbeidsmatkt. Het zou wellicht goed zijn als in cke lex-komst bij de bepaling van opleidlingen clie een adequate starlkwalificatie bieden ook rekening wordt gehouden met de opleidingssector die schoolverlaters helben gevolgd. 
$+\ldots$ 


\section{Literatuur}

Ministerie van Onderwijs, Cultuur en Wetenschappen (2002). Onderwijs Cultumr en Wetenschappen in kerncijfers. Den Haag: OCenW.

Researchcentrum voor Onderwijs en Arbeidsmarkt (2001). Scboolverlaters msien onderwijs en arbeidsmarkt 2000. Maastricht: ROA.

De Vries, M.R., \& Wolbers, M.H.J. (2002). Leerweg en arbeidsmarktintrede, In: A.M.L. van Wieringen \& W.A. Houtkoop (red.), De omgeving van bet beroepsonderwijs. Jaarboek 2001/2002 van bet Max Goote Kenniscentrum. Den Haag: Elsevier Overheid.

Van der Velden, R.K.W., De Vries, M.R. Wolbers M.H.J., \& Van Eijs, P. W. L. J. (2003). De waarde van een startkwalificatie. Amsterdam: Max Goote Kenniscentrum BVE (binnenkort te verschijnen). 


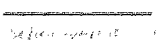




\section{Enkele centrale begrippen}

\section{Aansluitende functie naar niveau}

Een functie wordt als aansluitend naar niveau getypeerd indien het vereiste functieniveau ten minste gelijk is aan het genoten opleidingsniveau. Het functieniveau wordt bepaald aan de hand van de door de schoolverlaters beantwoorde vraag welk opleidingsniveau volgens de werkgever minimaal werd vereist.

\section{Aansluitende functie naar richting}

Een functie wordt als aansluitend naar richting getypeerd als de vereiste opleidingsrichting gelijk of verwant is aan de genoten opleidingsrichting. De vereiste opleidingsrichting wordt bepaald aan de hand van de door de schoolverlaters beantwoorde vraag welke opleidingsrichting volgens de werkgever werd vereist.

\section{Allochtoon}

Om als allochtoon te worden aangemerkt, dient de respondent of ten minste éen van zijn of haar ouders te zijn geboren in één van de landen die worden genoend in de Wel SAMEN (Stimulering Arbeidsdeelname Minderheden).

\section{Beroepsbevolking}

Tot de beroepsbevolking behoren:

- degenen die ten minste 12 uur per week werken of werk hebben aanvaard waardoor zij ten minste 12 uur per week gaan werken;

- degenen zonder werk (of met werk van minder dan 12 uur per week) die actief op zoek zijn naar werk, ten minste 12 uur per week willen werken en daarvoor besiduikbaar zijn (de laatste twee condities gelden alleen voor $\mathrm{HBO}$ en $\mathrm{WO}$ ).

In deze rapportage is tevens als voorwatarde gesteld dat de maatschappelijke posillie niet scholier of student is.

\section{Bruto uurloon}

Het bruto maandloon heeft betrekking op de baan waarin men het hoogste aantal uren werkt, inclusief toeslagen (ploegendienst, fooien, provisie e.d.), matr exclusief inkomen uil overwerk, vakantiegeld, 13e maand, uitkering e.d. Het bruto uurloon is gelijk aan het bruto maandloon, gedeeld door het aantal arbeidsuren per week in de batan waarin men het hoogste aantal uren werkt, vermenigvuldigd met de factor $12 / 52$. 


\section{Flexibele arbeidsrelatie}

Een flexibele arbeidsrelatie betreft een aanstelling als uitzendkracht, oproepkracht e.d of een aanstelling in tijdelijke dienst (met een contract korter dan één jaar - alleen voor HBO en WO).

\section{Intredewerkloosheid}

De intredewerkloosheid is het totaal aantal maanden sinds het verlaten van de oplei ding waarvan de schoolverlaters hebben aangegeven dat hun maatschappelijke positie in de betreffende matand werkloos was.

\section{Kwaliteit van het werk}

De kwaliteit van het werk geeft een samenvattend beeld van de gemiddelde beloning en de mate waarin de functie qua niveau en richting aansluit op de gevolgcle opleiding Deze wordt getypeerd aan de hand van het gemiddelde over alle onderscheiden oplei clingen.

\section{Maatschappelijke positie}

De maatschappelijke positie geeft de situatie weer die de schoolverlaters zelf het beste bij zich vinden passen (bijvoorbeeld betaald werk, scholier/student).

\section{Opleidingssector}

Binnen cle onderwijssoorten is een onderverdeling gemaakt naar verschillende sectoren, bijvoorbeeld techniek, economie e.d.

\section{$\overline{\text { Onderwijssoort }}$}

In het rapport worden de gediplomeerde schoolverlaters van de volgende onderwijs soorten onderscheiden:

AVO: algemeen voortgezel onderwijs

VBO: voorbereidend beroepsonderwijs. In deze rapportage valt ook het individuee voorlereidend beroepsonderwijs (IVBO) hieronder.

13OL: beroepsopleidende leerweg van het secundair beroepsonderwijs. Daarbinner wordt een onderscheid gemaakt tussen niveau $1 / 2$ (assistent beroepsbeofenaa (AB) en beginnend beroepsbeoefenaar (BB)) en niveau $3 / 4$ (zelfstandiy beroepsheoelenarar (ZB) en (midden-) kaderfunctionaris ((M)KF) of specialist).

BBL: bercepshegeleidende leerweg van het secundair beroepsonderwijs. Ook hie wordt het onderscheid tussen niveau $1 / 2$ en $3 / 4$ gemaakt.

HBO: hoger beroepsonderwijs

WO: welenschappelijk onderwijs 


\section{Werkgelegenheid en werkzekerheid}

De werkgelegenheid en werkzekerheid geeft een samenvattend beeld van het werkloosheidspercentage, de intredewerkloosheid en de mate warin schoolverlaters een vaste aanstelling hebben weten te verwerven. Deze wordt getypeerd aan de hand van het gemiddelde over alle onderscheiden opleidingen.

\section{Werkloosheid}

In deze rapportage wordt uitgegaan van de definitie van werkloze beroepsbevolking: schoolverlaters zonder werk (of met werk van minder dan 12 uur per week) die actief zoeken naar werk, minstens 12 uur per week willen werken en daarvoor direct beschikbaar zijn (de laatste twee condities gelden alleen voor HBO en WO). Dalubij is tevens als voorwaarde gesteld dat de matschappelijke positie niet scholier of student is. 